\title{
Environmental Health Indicators
}

for New Zealand:

Annual Report 2007

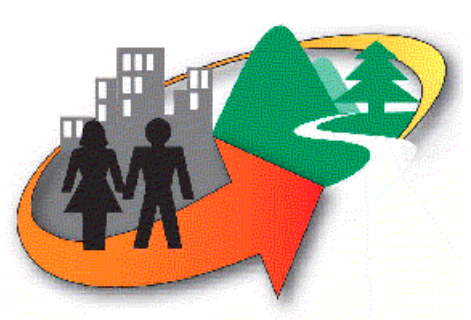

Prepared as part of a Ministry of Health contract for scientific services

by

Tammy Hambling

David Slaney

June 2007

Client Report

FW 0758 


\title{
Environmental Health Indicators for New Zealand: Annual Report 2007
}

\author{
Bruce Adlam \\ Ag. Science Programme Manager
}

Tammy Hambling

Project Leader 


\section{DISCLAIMER}

This report or document ("the Report") is given by the Institute of Environmental Science and Research Limited ("ESR") solely for the benefit of the Ministry of Health, Public Health Services Providers and other Third Party Beneficiaries as defined in the Contract between ESR and the Ministry of Health, and is strictly subject to the conditions laid out in that Contract.

Neither ESR nor any of its employees makes any warranty, express or implied, or assumes any legal liability or responsibility for use of the Report or its contents by any other person or organisation. 


\section{ACKNOWLEDGMENTS}

The authors would like to acknowledge that this report could not have been generated without the contributions and support of Toby Regan and Catherine Tisch (ESR), ESR Water group, Paul Franklin and Mike Thompson (MfE), Wayne Jones (MoT), Kheang Chrun (Land Transport New Zealand), Chris Lewis (NZHIS), MAF, Statistics New Zealand, Regional Councils, Territorial Local Authorities, Unitary Authorities and numerous other central government agencies. Their contributions and provision of EHI surveillance data is greatly appreciated.

The authors would like to thank and acknowledge the Ministry of Health and the World Health Organization, European Centre for Environment and Health, Environment and Health Information Programme especially Dr Dafina Dalbakova for all their help and contribution to the EHI project. 


\section{CONTENTS}

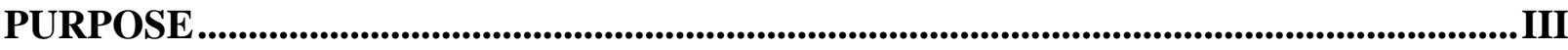

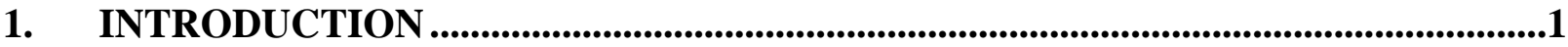

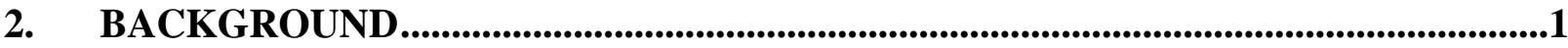

3. ENVIRONMENTAL HEALTH INDICATORS, FRAMEWORKS AND LINKAGES

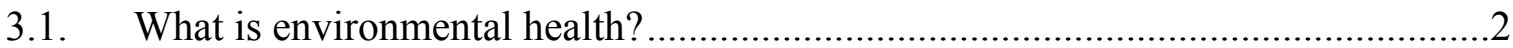

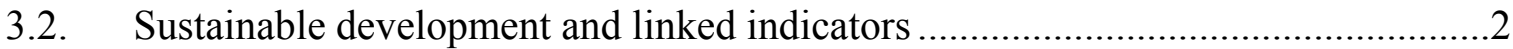

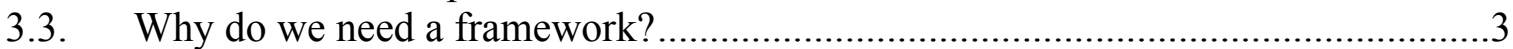

3.4. The World Health Organization DPSEEA framework .........................................

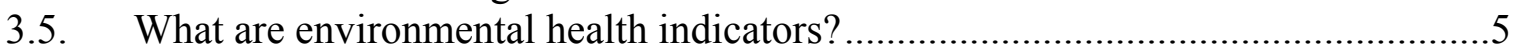

3.6. What are the uses of environmental health indicators?........................................6

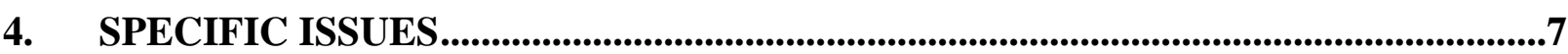

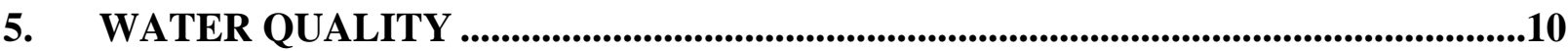

5.1. Driving forces influencing drinking and recreational water quality .....................10

5.2. Pressures on drinking and recreational water quality .......................................11

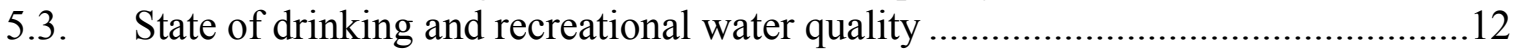

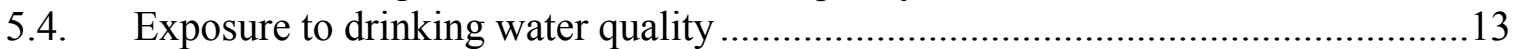

5.5. Health effects of poor drinking and recreational water quality............................13

5.6. Actions to reduce the burden of disease from poor water quality.........................24

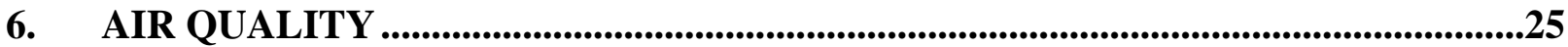

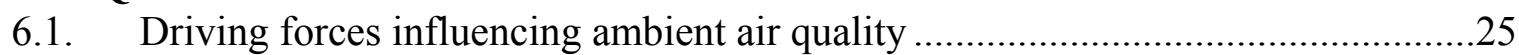

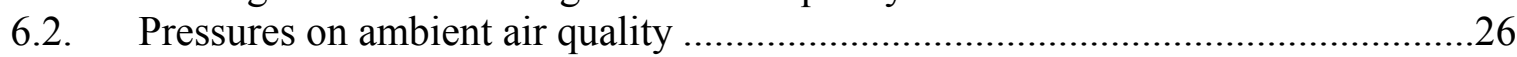

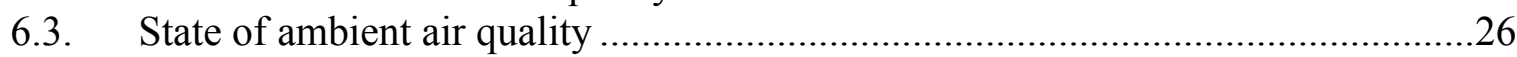

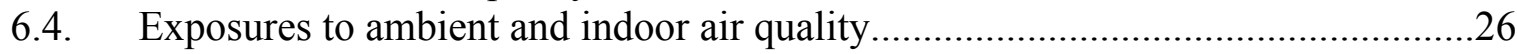

6.5. Health effects associated with poor ambient and indoor air quality ....................27

6.6. Actions to reduce the burden of disease from poor air quality ..............................39

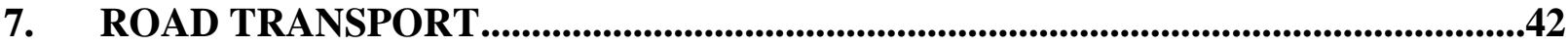

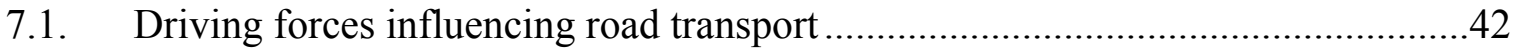

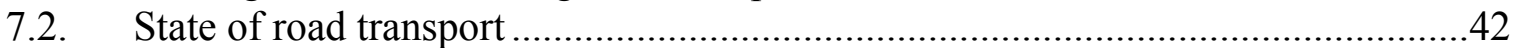

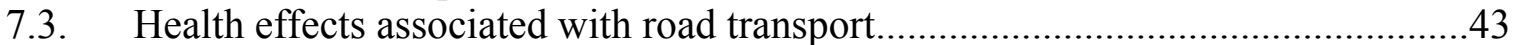

7.4. Actions to reduce the burden of injury from road transport..................................50

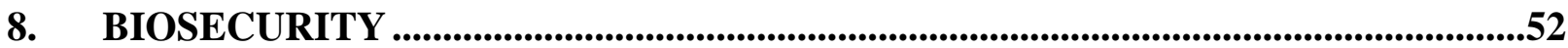

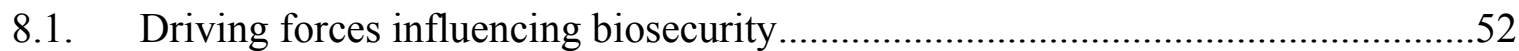

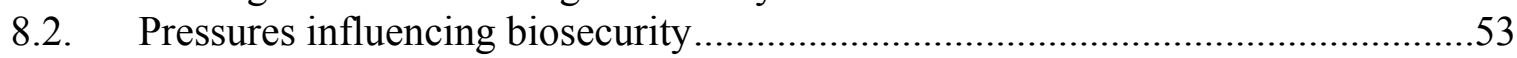

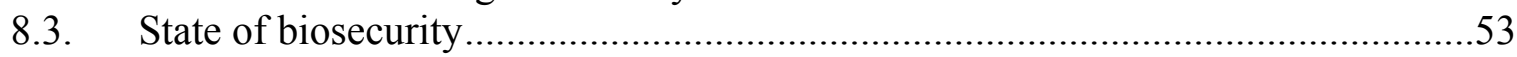

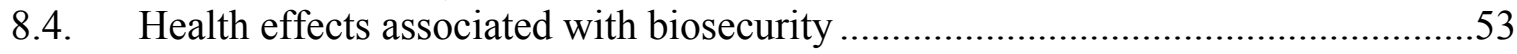

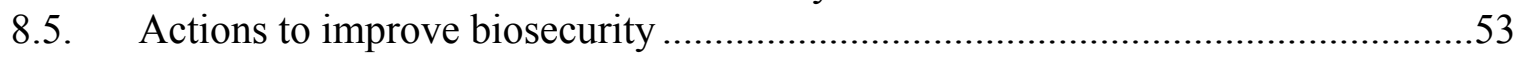

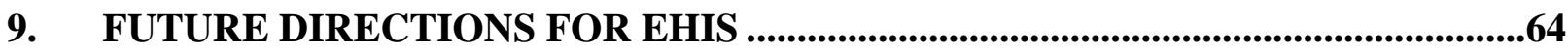

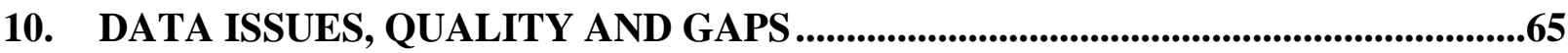

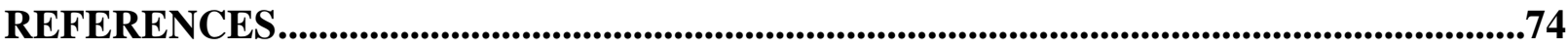

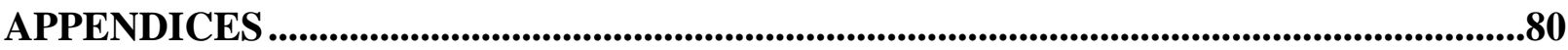

APPENDIX 1: THE DPSEEA FRAMEWORK.............................................................80

APPENDIX 2: REFERENCE MAP OF NEW ZEALAND FEATURING TERRITORIAL

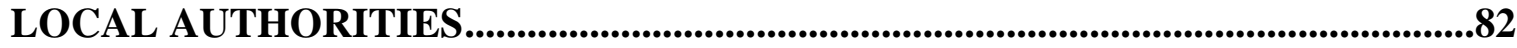


APPENDIX 3: SOCI-ECONOMIC DEPRIVATION INDEX MAP OF NEW ZEALAND83 


\section{LIST OF FIGURES}

Figure 1: DPSEEA framework ........................................................................................ 4

Figure 2: National environmental standard maximum pollution concentrations 2005 ........ 8

Figure 3: DPSEEA Framework: Water Quality Indicators ............................................ 10

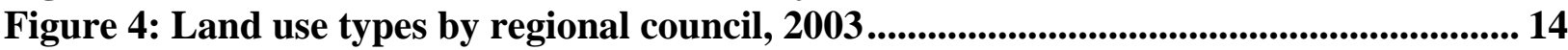

Figure 5: Livestock numbers by regional council, 2006 .................................................. 15

Figure 6: Wastewater treatment coverage - National, 2000-01 ......................................... 16

Figure 7: Annual E. coli exceedances by TLA, 2005 .................................................................. 17

Figure 8: Recreational water exceedances by Regional Council/Unitary Authority, 2006-07

bathing season ................................................................................................................................ 18

Figure 9: Population access to 'safe drinking water' by TLA, 2005 ................................ 19

Figure 10: Drinking waterborne diseases rate by TLA, 2006 ................................................... 20

Figure 11: Outbreaks of drinking waterborne diseases by TLA, 2006................................... 21

Figure 12: Recreational waterborne diseases rate by TLA, 2006 .................................... 22

Figure 13: DPSEEA Framework: Air Quality Indicators .................................................. 25

Figure 14: Percentage of total annual energy consumption by sector, 2005 ......................... 28

Figure 15: Percentage of total annual energy consumption by fuel type, 2005.................... 28

Figure 16: Percentage of dwellings using wood and/or coal by TLA, 2006............................ 29

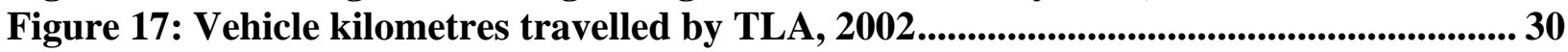

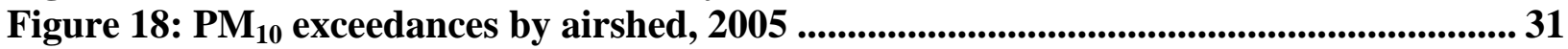

Figure 19: Percentage of dwellings using gas to heat dwellings by TLA, 2006 ..................... 32

Figure 20: Hospitalisation rate for respiratory diseases by TLA, 2005............................... 33

Figure 21: Hospitalisation rate for circulatory diseases by TLA, 2005 .................................. 34

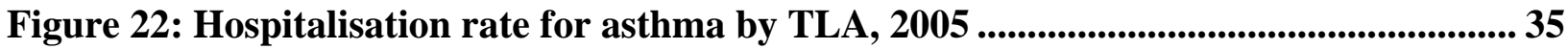

Figure 23: Mortality rate due to respiratory diseases by TLA, 2003.................................... 36

Figure 24: Mortality rate due to circulatory diseases by TLA, 2003 ....................................... 37

Figure 25: Prescription rate for asthma medication by TLA, 2005 .................................. 38

Figure 26: DPSEEA Framework: Road Transport Indicators ............................................... 42

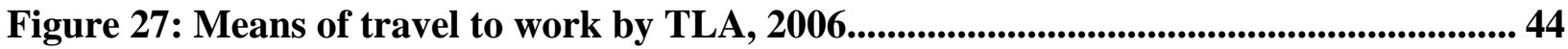

Figure 28: Vehicle kilometres travelled by TLA, 2002 .................................................. 45

Figure 29: Mean age (in years) of vehicles by TLA, 2006 ......................................................... 46

Figure 30: Serious injury rate due to road transport accidents by TLA, 2006................... 47

Figure 31: Mortality rate due to road transport accidents by TLA, 2006......................... 48

Figure 32: Potential years of life lost due to road transport accidents by TLA, 2006......... 49

Figure 33: DPSEEA Framework: Biosecurity Indicators................................................... 52

Figure 34: Overseas Cargo (gross weight) unloaded at sea and air ports, 1995-2006.......... 54

Figure 35: Number of vessels arriving direct from overseas sea ports, 2001-2005............... 55

Figure 36: Number of international passenger arrivals, 1954-2006.................................. 56

Figure 37: Number of used vehicles and machinery imported, 2000-2005 ........................... 57

Figure 38: World Health Organization reported overseas disease outbreaks, 2006 ............ 58

Figure 39: Variation in New Zealand's mean annual temperatures, 1855-2005 ................. 59

Figure 40: Distribution of exotic mosquito species in New Zealand, 2006 ........................60

Figure 41: Number of notified imported vector-borne disease cases in New Zealand, 1997-

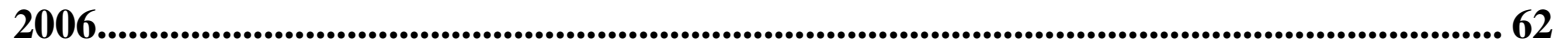

Figure 42: Biosecurity declaration infringements and undeclared seizures, 2001-2006 ..... 63

Figure 43: Research \& Development within the DPSEEA Framework .............................. 64 


\section{LIST OF ABBREVIATIONS}

C.C. $\quad$ City Council

$\mathrm{CO} \quad$ Carbon Monoxide

CoSINZ Community Sewerage Information New Zealand

DALYs Disability Adjusted Life Years

D.C. District Council

DPSEEA Driving forces - Pressures - State - Exposure - Effect - Action

E. coli Escherichia coli

EHI Environmental Health Indicator

EHIS Environmental Health Information System

ESR Institute of Environmental Science \& Research

EpiSurv National Notifiable Disease Surveillance System

LTSA Land Transport New Zealand (formerly Land Transport Safety Authority)

MAF Ministry of Agriculture and Forestry

MED Ministry for Economic Development

MfE Ministry for the Environment

$\mathrm{MoH} \quad$ Ministry of Health

MoT Ministry of Transport

NES National Environmental Standard

NIWA National Institute of Water and Atmospheric Research

$\mathrm{NO}_{2} \quad$ Nitrogen Dioxide

NOx Nitrogen Oxide

NZ New Zealand

NZHIS New Zealand Health Information Service

$\mathrm{O}_{3} \quad$ Ozone

PM Particulate Matter

$\mathrm{PM}_{2.5} \quad$ Particulate Matter $<2.5$ microns

$\mathrm{PM}_{10} \quad$ Particulate Matter $<10$ microns

PSR Pressure - State - Response

PYLL Potential Years of Life Lost

R.C. Regional Council

RMA Resource Management Act (1991)

SARS Severe Acute Respiratory Syndrome

$\mathrm{SO}_{2} \quad$ Sulphur Dioxide

SOx Sulphur Oxide

SFRG Suitability for Recreation Grade

TLA Territorial Local Authority

VTEC Verotoxigenic Escherichia coli

VOC Volatile Organic Compound

WINZ Water Information New Zealand

WHO World Health Organization

YLL Years of Life Lost 


\section{PURPOSE}

This report has two principal objectives. Firstly, to offer a basis for a better understanding of some of the environmental factors affecting human health, with the aim of illustrating the potential of indicators as a tool for environmental health decision-making. Four key issues water quality, air quality, road transport and biosecurity have been chosen to illustrate this.

The second objective of this report is to provide a resource for discussion about how to reduce the burden of disease due to the environment, in part through identifying or developing measures to track and better understand environmental health issues and, ultimately, to identify and evaluate ways to improve it. The indicators outlined in this report are a starting point and should not be considered an exhaustive list. All analyses in this report are based on data obtained prior to June 2007. 


\section{INTRODUCTION}

There is a longstanding recognition that good health and wellbeing are linked with the state of the environment. However, multiple factors influence the health of individuals and populations, including the physical and social environment, genetics, lifestyles and access to education, income, food, housing, and health services.

The goal of this project is to improve understanding of the links between the physical environment people live in, their health outcomes and the risk of exposure, through the development of an integrated information system of environmental health indicators (EHIs). This will enhance the translation of scientific knowledge on exposure-response relationships into a measure of environmental health status, while illustrating actions of showing how a health problem can be handled effectively.

Decision makers need better data both on the linkages between factors in the environment and how they affect human health, and how they can be incorporated into a sustainable development framework.

An Environmental Health Information System (EHIS) based on EHIs and the Driving forces, Pressure, State, Exposure, Effect, Action (DPSEEA) framework is a proven tool for monitoring and evaluating the implementation and modification of policies, by providing systematically collected and analysed evidence.

The EHIS is the ongoing collation, integration, analysis, interpretation and dissemination of data on environmental hazards, exposures to these hazards and related health effects.

The benefits of such a system are to:

- Assess environmental health risk using routinely collected data.

- Provide timely information to all users.

- Integrate databases of environmental hazards, environmental exposures and health effects.

- Enable ongoing analyses, integration, and interpretation of hazards, exposure and health effects data to control, mitigate and prevent environmentally related health problems.

- Assist research by providing easier access to environmental and population health data.

\section{BACKGROUND}

The Ministry of Health $(\mathrm{MoH})$ has a statutory responsibility to monitor and report on the state of the public health. This has been done through annual reports on progress towards specific health targets Progress on Health Outcome Targets (Ministry of Health 1999a) and five-yearly reports on population health and health determinants Our Health Our Future (Ministry of Health 1999b) and Social Inequalities in Health (Ministry of Health 2000). A key action for the MoH in Achieving Health for All People (Ministry of Health 2003) is the development of a set of key health indicators for monitoring the overall health of the population of New Zealand.

A balanced set of indicators is required to provide a suitable overview of issues as complex as population health and influences on population health. Each indicator should satisfy at least some of the following criteria:

- Reflect an important aspect of population health.

- Sensitive to differing health status between population groups. 
- Contribute to a balanced set of measures, that is, they include:

o All cause and cause specific outcomes.

o Whole of life and life-stage-specific measures.

o Causes of health outcomes, including risk factors as well as injuries and diseases.

o Fatal and non-fatal health outcomes.

- Able to be updated at least every five years.

- Where possible, allow international comparison.

\section{ENVIRONMENTAL HEALTH INDICATORS, FRAMEWORKS AND LINKAGES}

\subsection{What is environmental health?}

Environmental health comprises those aspects of human health and diseases that are influenced by factors in the environment. It includes both the direct pathological effects of chemicals, ionising and non-ionising radiation and some biological agents. It also includes the effects (often indirect) on health and wellbeing of the broad physical, psychological, social and aesthetic environment which includes housing, urban development, land use and transport (The European Charter and Commentary 1989).

\subsection{Sustainable development and linked indicators}

The concept of sustainable development is one way to frame the interrelationships between the environment and health. Internationally, sustainable development is an integrated approach that examines social, economic and environmental implications. The World Commission on Environment and Development defined sustainable development as "development which meets the needs of the present without compromising the ability of future generations to meet their own needs" (Bruntland 1987).

Sustainable development has international recognition, particularly in ongoing work resulting from the 1992 United Nations Earth Summit. It has gained currency in New Zealand through the Sustainable Development Programme of Action, which states that indicators are needed to assess New Zealand progress towards sustainable development.

Health is closely intertwined with the goal of sustainability. Sustainable development has often been associated solely with the environment. However, it is actually about ensuring the health and wellbeing of people, in tandem with environmental goals. Indeed the first principle of the Rio Declaration for Environment and Development (United Nations 1992) is that human beings are at the centre of concerns for sustainable development. They are entitled to a healthy and productive life in harmony with nature. Good health is a fundamental goal of development as well as a means of accelerating it. Health is important not only for how it extents life and improves its quality - it is also an important contributor to social and economic development. As such human activities such as economic development and social changes can be considered as "driving forces" as to whether a society proceeds towards or away from sustainability (World Health Organization 1997). Such driving forces and subsequent pressure on the environment may be sources of various types of environmental hazards such as pollutants. 
The EHIs being developed by ESR for the MoH can be linked to a number of informationgathering projects being undertaken by government agencies. The principal ones are:

- Ministry for the Environment's (MfE) Environmental Performance Indicators

- Ministry of Social Development (2006) 'The Social Report' - two indicators used are: air quality and drinking water quality.

- Quality of Life Survey 2006, National Report (TNS 2007)

- Statistics New Zealand (2002) has been developing a set of socioeconomic indicators, which are intended to show the underlying social and economic driving forces behind environmental pressure and their changes over time.

- Ministry of Transport (MoT) is developing key transport indicators to measure progress against the New Zealand Transport Strategy objectives.

\subsection{Why do we need a framework?}

A conceptual framework helps to interpret a complex issue like environmental health by demonstrating links or relationships between the environment and human health. It is a broad representation of the understanding based on existing knowledge. The main role of a conceptual framework is to organise the concepts, ideas and notions of a subject in a meaningful way (enHealth Council 2002).

Robust frameworks have:

- Conceptual clarity and scope - ensuring that the framework covers all key concepts and includes logical and plausible links.

- Flexibility - allows for consideration of the issue at any stage or component of the framework.

- Balance - the framework accommodates issues with an environmental or health emphasis equally well.

- Usability - the framework lends itself to a viable methodology for developing suitable indicators.

Developing EHIs requires identifying links between environmental factors and human health outcomes. A framework that groups indicators into determinants and outcomes becomes a useful tool for achieving this aim. This approach is much more useful and informative than simply presenting indicators as a simple list (Environment Canada 2002). 


\subsection{The World Health Organization DPSEEA framework}

\section{Figure 1: DPSEEA framework}

(Illustrating the six components of the environmental health chain; Driving Forces, Pressures, State, Exposures, Effects and Actions)

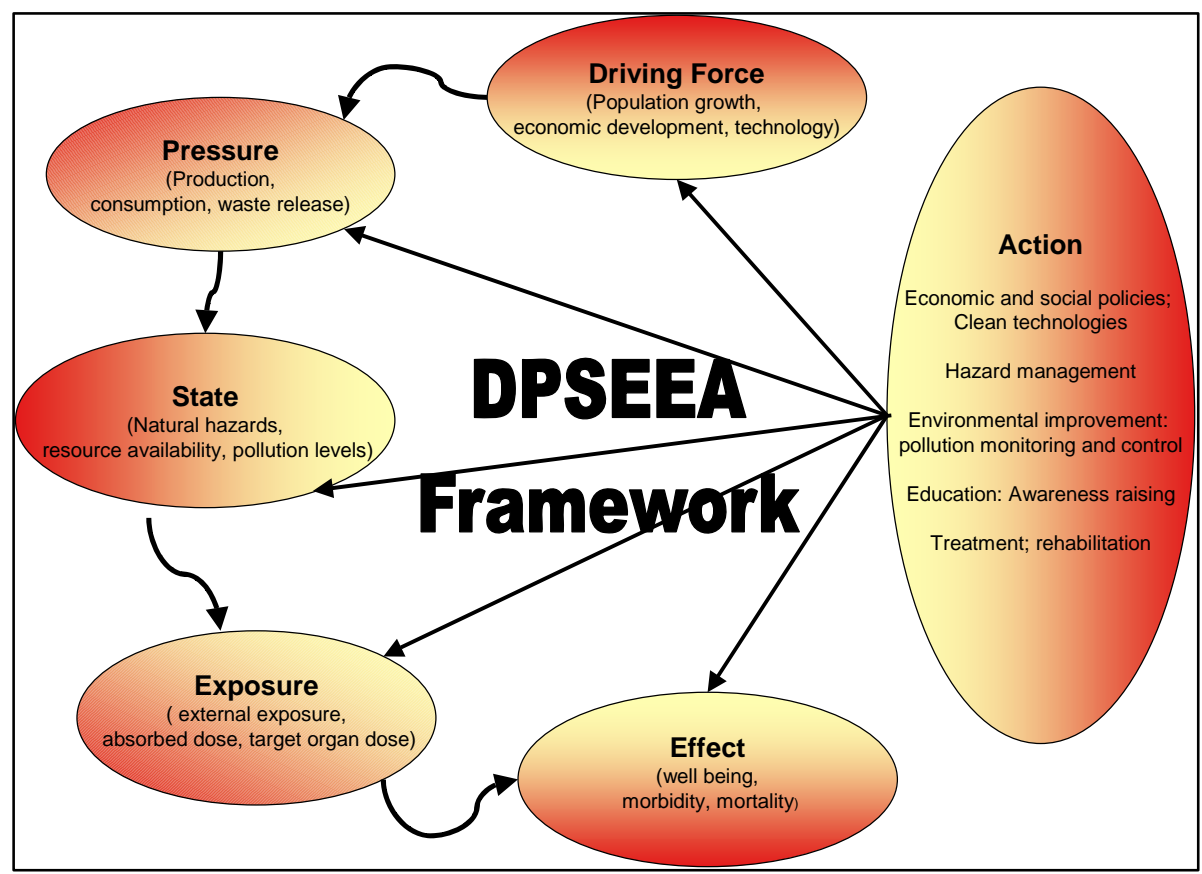

The DPSEEA framework is a descriptive representation of the way in which various driving forces generate pressures that affect the state of the environment and ultimately human health, through various exposure pathways by which people come into contact with the environment (Figure 1; Appendix 1 for more detail). The main difference compared to other frameworks is that the focus is from a human health perspective.

The DPSEEA framework, like the Pressure - State - Response (PSR) framework on which it is based, shows the components in a linear fashion to represent the connections between factors affecting health and the environment more clearly. In reality, the situation is more complex, because various interactions occur at different levels between various components.

The framework takes account of the fact that, various factors responsible for health and environmental problems may be associated with driving forces such as population growth, economic development, technological change and the policies underlying them.

Pressures may be exerted on the environment which cause sectors to generate various types of outputs (e.g. pollutant emissions), causing the "state" (quality) of the environment to be degraded through the dispersal and accumulation of pollutants in various environmental media, such as air, soil, water and food.

People may become "exposed" to potential hazards in the environment when they come into direct contact with these media, through breathing, drinking or eating. A variety of health effects may subsequently occur, ranging from minor effects to illness and death, depending on the toxicity of the pollutant, the degree of exposure and the susceptibility of the individuals exposed. 
Various "actions" can be implemented at different points of the framework and may take a variety of forms, including policy development, standard setting, technical control measures, health education or treatment of people with diseases (Corvalan \& Kjellstrom 1995; Kjellstrom \& Corvalan 1995; Pastides 1995; von Schirnding 2002).

\subsection{What are environmental health indicators?}

An Environmental Health Indicator (EHI) is defined as:

"An expression of the link between environment and health targeted at an issue of specific policy or management concern and presented in a form, which facilitates interpretation for effective decision making" (Briggs, Corvalan et al. 1996).

There are two important aspects to this definition. The first is an EHI provides information about a scientifically based linkage between environment and health. The second is its relationship with policy and management implying monitoring and action (Kjellstrom \& Corvalan 1995).

EHIs tell us about the effects of the environment on health. Therefore, they are based on an interpretable relationship between environment and health. Indicators are presentations of measurements that summarise the characteristics of systems or highlight what is happening in a system.

The main criteria for an EHI are:

- Routinely collected data to be used.

- Meaningful summary of the conditions of interest.

- International benchmarking capability.

- Scientifically sound.

- Sensitive and specific to real changes in the conditions being measured.

There are three types of indicators:

- Human health effects that are caused by or associated with environmental exposure.

- Measures of environmental quality that have the potential to affect human health.

- Activities that place pressures on the environment or/and increase the possibility of exposure in vulnerable populations.

The New Zealand EHI project has adhered to international best practice by adopting the conceptual framework, the DPSEEA framework endorsed by the World Health Organization (WHO) to organise its own EHI programme. The WHO started their EHI programme in 1999 in collaboration with the European Environmental Agency and the European Commission. The indicators have been piloted and tested in 15 countries in Europe. The detailed methodology for individual indicators was developed by world experts and reviewed at working group meetings involving a wide range of multidisciplinary expertise and several countries. The United States and Canada have recently decided to follow the WHO Europe programme.

The New Zealand EHI project has been working closely with WHO Europe and has contributed significantly to the global initiative and more recently has developed strong links with programmes in the United States and Australia.

The indicators presented in this report reflect the WHO indicators. There have been a few changes and additions to the original WHO indicators to reflect variation in data availability 
and other issues specific to New Zealand. These changes have been a result of the consultation and feedback received over previous years from various agencies.

The EHI project does not replace any other indicator project currently being undertaken by central or local government agencies, but rather adds the human health dimension to the other indicator initiatives. For example, it builds upon the work done by the MfE's Environmental Performance Indicators Programme that specifically relates to policy objectives under the Resource Management Act 1991. This includes recent National Environmental Standards (NES) under the Resource Management Regulations 2004, other national environmental policies and legislation as well as the state of the environment reporting from individual regional councils/unitary authorities. To date, there has not been a national system for regularly taking stock of the relationship between environmental factors and human health outcomes. This project is the first to do so in a structured manner.

\subsection{What are the uses of environmental health indicators?}

Indicators are powerful communication tools for policy-makers, experts and the general public; when integrated with the policy-making process, they can demonstrate the effectiveness of environment and health policies, thus facilitating the setting of priorities among competing policies. They provide evidence that complements epidemiological data to inform policy development.

Indicators provide evidence for the potential benefits of policies; they enable the assessment of the potential impact of environment and health policy on the health of the population. Spatial and temporal analysis of the indicators further facilitates this process.

Indicators support priority setting for policy-makers; by providing comparative information, feasible policy interventions can be prioritized based on the best available evidence.

Indicators identify examples of good practice; it is envisaged that the EHI reporting will provide examples of good practice among participating organisations.

Indicators help monitor global progress by providing a uniform approach to monitoring time trends in regions or in countries. This is important if the countries and agencies are to introduce collaborative policies on environment and health.

Indicators can be hypothesis - generating tools, as they will be able to identify data gaps as well as areas where there is a marked difference between one area and the national average. 


\section{SPECIFIC ISSUES}

This report focuses on four environmental health issues namely, water quality (drinking and recreational), air quality (ambient and indoor), road transport and biosecurity.

These issues were chosen mainly because the public has highlighted them in several surveys as key concerns, e.g. in a biennial survey in 2006 by Lincoln University, pollution (air, water and solid waste disposal) was rated as the most important environmental issue facing New Zealand (Hughey, Kerr et al. 2006)

Other local surveys show similar concerns, e.g. the Auckland Regional Council's Environmental Awareness Survey carried out in 2003/2004 found that respondents were either concerned or very concerned about traffic congestion (90\%), water pollution $(86 \%)$ and air pollution (76\%) (Auckland Regional Council 2004).

In recent years, there has also has been growing public awareness of biosecurity issues. For example, it has been members of the public that initially alerted authorities of the presence of the southern saltmarsh mosquito, the painted apple moth, and the red imported fire ant (Audit Office 2002).

Policy initiatives will affect future water quality as reflected in proposed new legislation, the Health (Drinking Water) Amendment Bill (currently with the health select committee). Another initiative, the Sustainable Water Programme of Action (administered by the MfE), which falls under the Sustainable Development Programme of Action, is to identify preferred policy directions for improving water management. The Sustainable Water Programme of Action consists of a number of projects within three separate strands covering: water allocation and use; water quality; and water bodies of national importance.

The Drinking Water Assistance Package (administered by the $\mathrm{MoH}$ ) will provide funding to local authorities and private water suppliers for technical advice and direct capital assistance with upgrading water supplies. The MfE is working with the $\mathrm{MoH}$ to introduce a "multibarrier" approach to managing human drinking water in response to risks presented by potential contaminants. The proposed NES publicly notified in September 2005, takes a pragmatic approach to protecting drinking water sources and advocates consultative processes to identify and minimise potential cost impacts. The proposed standard formalises practices and procedures already provided for, but that are variably applied, in order to minimise adverse effects on drinking water sources, and other freshwater systems.

In terms of air quality, the MfE has introduced the Resource Management (NES's Relating to Certain Air Pollutants, Dioxins, and Other Toxics) Regulations 2004. On the $8^{\text {th }}$ October 2004, the first of the standards came into effect. The standards aim to create a level playing field across New Zealand, provide certainty and consistency, guarantee a similar level of protection for the health of New Zealanders, and drive effective regional and national policies to improve air quality. The fourteen air quality standards include:

- Seven activity standards that ban various activities that discharge unacceptable quantities of dioxins and other toxics into the air. These standards that came into effect on the $8^{\text {th }}$ October 2004 include the burning of coated wire in the open: deliberate landfill fires; burning of tyres in the open; burning of road tar seal (bitumen burn off); and burning of waste oil in the open. In addition no new high temperature hazardous waste incinerators will be allowed from the $1^{\text {st }}$ October 2006 while the use of school and hospital incinerators will be banned unless they have obtained resource consent. 
- A design standard for new small-scale domestic wood-burning appliances in urban areas to minimise emissions of smoke and soot which came into effect on the $1^{\text {st }}$ September 2005.

- A design standard for the collection and destruction of landfill gas at large landfills (over one million tonnes), which came into effect on the $8^{\text {th }}$ October 2004.

- Five ambient air quality standards, which became effective from September 2005 (Figure 2). The pollutants covered are carbon monoxide $(\mathrm{CO})$, fine particles $\left(\mathrm{PM}_{10}\right)$, nitrogen dioxide $\left(\mathrm{NO}_{2}\right)$, sulphur dioxide $\left(\mathrm{SO}_{2}\right)$ and ozone $\left(\mathrm{O}_{3}\right)$. As of the $1^{\text {st }}$ September 2005 regional councils are required to monitor air quality for these pollutants and publicly report any exceedances.

Figure 2: National environmental standard maximum pollution concentrations 2005

\begin{tabular}{|l|l|l|l|}
\hline \multicolumn{1}{|c|}{ Contaminant } & \multicolumn{1}{|c|}{$\begin{array}{c}\text { Threshold } \\
\text { Concentration }\end{array}$} & $\begin{array}{c}\text { Averaging } \\
\text { period }\end{array}$ & \multicolumn{1}{|c|}{ Permissible excess } \\
\hline Carbon monoxide $(\mathrm{CO})$ & $10 \mathrm{mg} / \mathrm{m}^{3}$ & $\begin{array}{l}8 \text { hour } \\
\text { running mean }\end{array}$ & $\begin{array}{l}\text { One } 8 \text { hour period in } \\
\text { any } 12 \text { month period }\end{array}$ \\
\hline Nitrogen dioxide $\left(\mathrm{NO}_{2}\right)$ & $200 \mu \mathrm{g} / \mathrm{m}^{3}$ & 1 hour mean & $\begin{array}{l}9 \text { hours in any } 12 \\
\text { month period }\end{array}$ \\
\hline Ozone $\left(\mathrm{O}_{3}\right)$ & $150 \mu \mathrm{g} / \mathrm{m}^{3}$ & 1 hour mean & Not to be exceeded \\
\hline Particulate Matter $\left(\mathrm{PM}_{10}\right)$ & $50 \mu \mathrm{g} / \mathrm{m}^{3}$ & 24 hour mean & $\begin{array}{l}\text { One 24 hour period in } \\
\text { any 12 month }\end{array}$ \\
\hline Sulphur dioxide $\left(\mathrm{SO}_{2}\right)$ & $350 \mu \mathrm{g} / \mathrm{m}^{3}$ & 1 hour mean & $\begin{array}{l}9 \text { hours in any } 12 \\
\text { month period }\end{array}$ \\
& $570 \mu \mathrm{g} / \mathrm{m}^{3}$ & 1 hour mean & Not to be exceeded \\
\hline
\end{tabular}

Data source: Resource Management (National Environmental Standards Relating to Certain Air Pollutants, Dioxins, and Other Toxics) Regulations 2004.

With respect to other important air pollutants, $\mathrm{PM}_{2.5}$ monitoring is very limited in New Zealand but available data indicates that sites that experience exceedances of $\mathrm{PM}_{10}$ from combustion sources are likely to experience a greater number of exceedances of $\mathrm{PM}_{2.5}$ (since the reporting guideline concentration is lower).

Recent policy developments intended to reduce harmful emissions from vehicles include the government introduction in October 2006 that all vehicles must pass a five-second visible smoke check in order to obtain their warrant or certificate of fitness (Ministry of Transport 2007).

The 'Petroleum Products Specifications Regulations 2002' administered by the Ministry of Economic Development complements the initiatives being carried out by the MoT for improving air quality. From the $1^{\text {st }}$ January 2006 the Regulations required that the maximum permitted sulphur levels be no more than $50 \mathrm{ppm}$ (parts per million) for diesel (diesel sole for marine use is exempt) and $150 \mathrm{ppm}$ for petrol. Further reductions in sulphur levels are indicated in the Regulations: diesel sulphur content of $50 \mathrm{ppm}$ from 2008; and the ultimate requirement of "sulphur free" petrol of 10-15 ppm maximum sulphur content.

In terms of biosecurity, the New Zealand government has responded to help safeguard New Zealand's economy, environment and human health. New Zealand's Biosecurity Act passed in 1993, was a world first. In September 2001, the Ministry of Agriculture and Forestry (MAF) launched a national publicly funded programme 'Protect New Zealand' to raise awareness of biosecurity issues and inform people of biosecurity risks and measures to reduce these risks. Then in 2003, the Biosecurity Strategy was launched in response to mounting pressures on New 
Zealand's biosecurity system (Biosecurity Council 2003). The Biosecurity Strategy is a partnership approach involving Government, industry, non-government organisations, regional councils, Maori and the public. The strategy, sets out an overall direction for biosecurity, and contains a detailed list of expectations for the next 5 - 10 years. Specifically, the key elements of the strategy are to:

- Set an overall direction for biosecurity

- Identify areas of priority for biosecurity programmes

- Apply to primary production (agriculture, horticulture, forestry), public health, and indigenous terrestrial, marine, and freshwater environments

- Provide guidance to all involved in biosecurity

- Raise public awareness and understanding of biosecurity.

Following the release of the Biosecurity Strategy, MAF confirmed its intention to restructure its Biosecurity Authority, replacing the former 'MAF Biosecurity' and 'Protect New Zealand' brands, to form 'Biosecurity New Zealand', which started operation on $1^{\text {st }}$ November 2004 (Ministry of Agriculture and Forestry 2006). The establishment of Biosecurity New Zealand saw the consolidation of some central government biosecurity services within MAF, while other services will continue to be delivered by agencies such as the Department of Conservation, $\mathrm{MoH}$ and Land Information New Zealand (Ministry of Agriculture and Forestry 2006). 


\section{WATER QUALITY}

Figure 3: DPSEEA Framework: Water Quality Indicators

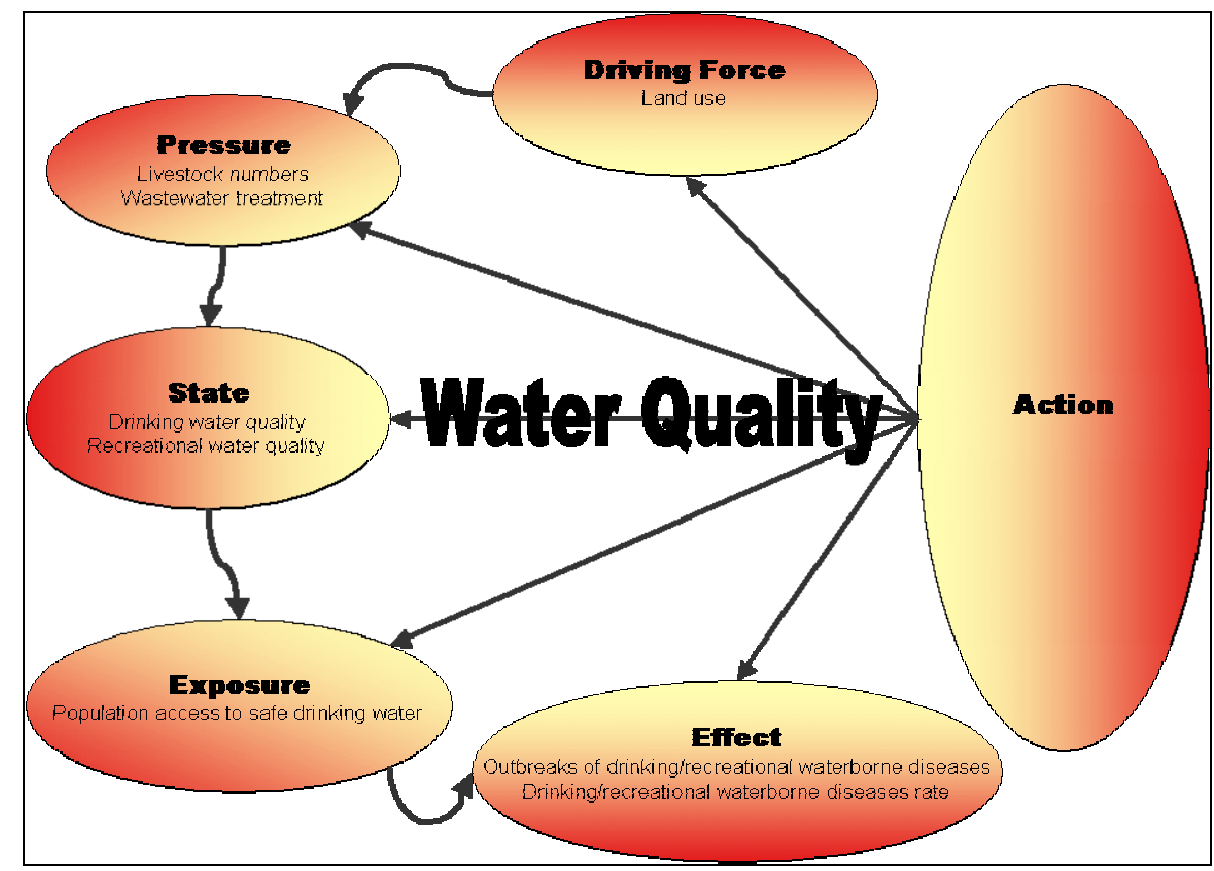

Water availability and quality have marked effects on human health. It is estimated that globally, poor water quality, supply, sanitation and hygiene account for $5.7 \%$ of the total disease burden or 84 million years of life lost per annum (World Health Organization 2004a; Pruss, Kay et al. 2002).

Untreated or inadequately treated water contaminated by waste presents a significant health risk. Both microbial agents and chemicals can enter the water supply from waste and are not always effectively removed at water treatment plants and may be associated with widespread ill health.

Contaminated lakes, rivers and coastal waters when used for recreation can also cause healthrelated problems including gastrointestinal, respiratory, ear, eye and skin symptoms (Cabelli, Dufour et al. 1982; Kay, Fleisher et al. 1994).

\subsection{Driving forces influencing drinking and recreational water quality - Land use (Figure 4).}

Sixty percent of New Zealand's drinking water comes from lakes and rivers, the remainder is from groundwater. The main sources that impact water quality in the environment are agriculture, human sewage, urban storm water, industry, mining and forestry (Ministry for the Environment 1997).

The land use indicator highlights influences on water systems (Figure 4). This is intimately linked with other driving forces such as economic development and population growth. Water quality and quantity in streams, rivers, wetlands, estuaries, lakes and groundwater depends mainly on land use in their catchment areas. Farming and horticulture are major contributors to New Zealand's export earnings. 
Land use patterns exert different pressures on source water. The three main land use activities that impact on water quality are rural land use and intensified agricultural use, urban storm water and point source discharges, and runoff from roads (Ministry for the Environment 2004a). Landfills and the cumulative effects of on-site effluent treatment systems are other potential point source discharges, which can impact on water quality. The main distinction between urban land use and rural land use is that urban land use is primarily associated with point source pollution (although it may also be associated with diffuse water pollution from runoff) whereas rural use is primarily associated with diffuse water pollution. Thus, point source pollution can be managed through discharge permits whereas diffuse pollution needs other management tools.

\subsection{Pressures on drinking and recreational water quality \\ - Livestock numbers (Figure 5). \\ - Wastewater treatment (Figure 6).}

Agricultural land use and urbanisation are two key pressures that affect both drinking and recreational water quality. These specific types of land use exert pressures on the environment in the form of livestock numbers and generation of wastewater (Figures $5 \& 6$ ). The main risk to water quality in New Zealand is that livestock have access to catchments of surface water supplies. The other risk is the discharge of inadequately treated sewage/waste water to sea and/or rivers resulting in closures for bathing recreation and shellfish gathering. Pastoral agriculture has been implicated as the single largest cause of water pollution in New Zealand (Wilcock 1986; Smith, Wilcock et al. 1993; Ministry for the Environment 1997). A recent study has demonstrated that dairy cows walking through streams cause water contamination, with Escherichia coli (E. coli) levels temporarily elevated to more than one hundred times background levels and more than one hundred times the guidelines for contact recreation (Davies-Colley, Nagels et al. 2004).

The ongoing pressure for changing rural use can lead to more inorganic pollutants entering water bodies (e.g. nitrogen or phosphorus from fertilisers; nitrogen/ammonia from animal urine or silage; micro-organisms from animal faeces; sediment from stock pugging). Nitrate-nitrogen concentrations in shallow groundwater frequently exceed $\mathrm{MoH}$ drinking water standards where stock densities are high and upper soils permeable. Cases receiving attention are discussed in Environment Canterbury's (Canterbury Regional Council) recent report on high nitrate concentrations in groundwater southeast of Ashburton District's three meat processing plants and in the coastal region around Dorie/Pendarves, an irrigated arable crop area (Hanson \& Hayward 2004).

The community sewerage survey 2000-2001 (CoSINZ) indicated that 95\% of respondents were connected to a reticulated sewerage system with most treated wastewater discharging to land or into rivers, estuaries and the sea. If the indicator is to be useful then information would have to be gathered on the $5 \%$ of respondents who are not connected to a reticulated sewerage system and have no adequate local disposal facilities. Another method of wastewater disposal is onsite sewage using septic tanks and soakage trenches or holes. If properly maintained and sited in areas of low population density the environmental effects are minimal. Potential problems exist where the density of septic tanks is high, or where effluent soakage is poor or excessive, leading to groundwater contamination. This indicator does not take into account contamination from other sources of faecal material, particularly that of farm animals, which is particularly relevant to New Zealand. 


\subsection{State of drinking and recreational water quality \\ - Drinking water quality (Figure 7). \\ - Recreational water quality (Figure 8).}

The state of the environment is affected by various pressures on it such as agricultural land use and livestock numbers as well as urbanisation and wastewater treatment.

High livestock densities can impact on water supplies by increasing the pathogen load and the nitrogen content of water bodies. This can lead to illness from ingesting the contaminated water. The two main ways to minimise risk from illness arising from these contaminants is to keep the source water clean and treat the water before distribution.

Escherichia coli presence in drinking water is used to indicate that the water has been subjected to recent faecal contamination. If $E$. coli is present, there is also a greater risk of other pathogens being present. Thus, annual E. coli exceedance is a good general indicator of the state of drinking water quality (Figure 7).

For drinking water supply, compliance is determined by considering how the quality of the water compares with the requirements of the Drinking Water Standards for New Zealand 2005. This value takes into account the monitoring regime, quality procedures and processes.

There is currently little information on the quality of drinking water sources available nationally. The MfE in consultation with the MoH has developed a NES for sources of human drinking water which aims to improve how drinking water is managed at source. This standard has now been gazetted and will take effect at the end of 2007. This standard will complement the MoH's legislation and standards for improving drinking water supply and delivery and ensure a comprehensive approach to managing drinking water from source to tap.

Two recent studies of the environmental quality of New Zealand rivers found that E. coli concentrations exceeded the guideline in most of the land cover classes and were most pronounced where climate is driest, and where the catchment is dominated by pastoral land cover (Larned, Scarsbrook et al. 2005; Snelder \& Scarsbrook 2005).

Poor recreational water quality may also affect human health. Rural and urban run-off can contain both human and animal faeces. In times of high rainfall the pathogens present in animal faeces can be transferred into waterways via storm water drains or overland flow. For urban catchments, contamination at beaches could be elevated by inflow and infiltration of storm water into the sewer system. Exposure to pathogens in recreational water have been associated with gastrointestinal, respiratory, ear, eye and skin symptoms (Cabelli, Dufour et al. 1982; Kay, Fleisher et al. 1994).

Both freshwater (lakes, rivers and streams) and marine water (beaches) are monitored by councils, generally in the summer months (Figure 8). The Microbiological Water Quality Guidelines for Marine and Freshwater Recreational Areas produced by the MfE and MoH and released in 2003 have moved away from the sole use of guideline values of faecal indicator bacteria, and instead use a combination of a qualitative risk grading of the catchments, supported by the direct measurement of appropriate faecal indicators to assess the suitability of a site for recreation. These combined give an overall Suitability for Recreation Grade (SFRG), which describes the general condition of a site at any given time, based on both risk and indicator bacteria counts (Ministry for the Environment 2002). However it is still useful to understand the percentage of beaches in each area exceeding the guideline values. This provides another method of analysing water quality data in terms of health risk. 


\subsection{Exposure to drinking water quality \\ - Population access to safe drinking water (Figure 9).}

Deterioration in the state of water quality only affects human health if people are exposed; population access is the most robust routinely collected dataset to reflect this (Figure 9).

The issue of effective monitoring of recreational water and ensuring it is safe is of special significance in New Zealand due to a high proportion of people accessing these waters. A 2004 survey found that $79 \%$ New Zealanders identified themselves as recreational users of freshwater (BRC Marketing and Social Research cited in Ministry for the Environment 2004b).

\subsection{Health effects of poor drinking and recreational water quality \\ - Drinking/recreational waterborne diseases rate (Figures 10 \& 12). \\ - Outbreaks of drinking/recreational waterborne diseases (Figure 11).}

Contact with microbial contaminated water is one of the risk factors for a number of diseases in New Zealand such as viral hepatitis, campylobacteriosis, cryptosporidiosis, giardiasis and gastroenteritis. Four effect indicators that are useful measures of the health effects of poor drinking and recreational water quality are the rate of waterborne diseases and the number of disease outbreaks associated with both water sources (Figures 10 to 12). 


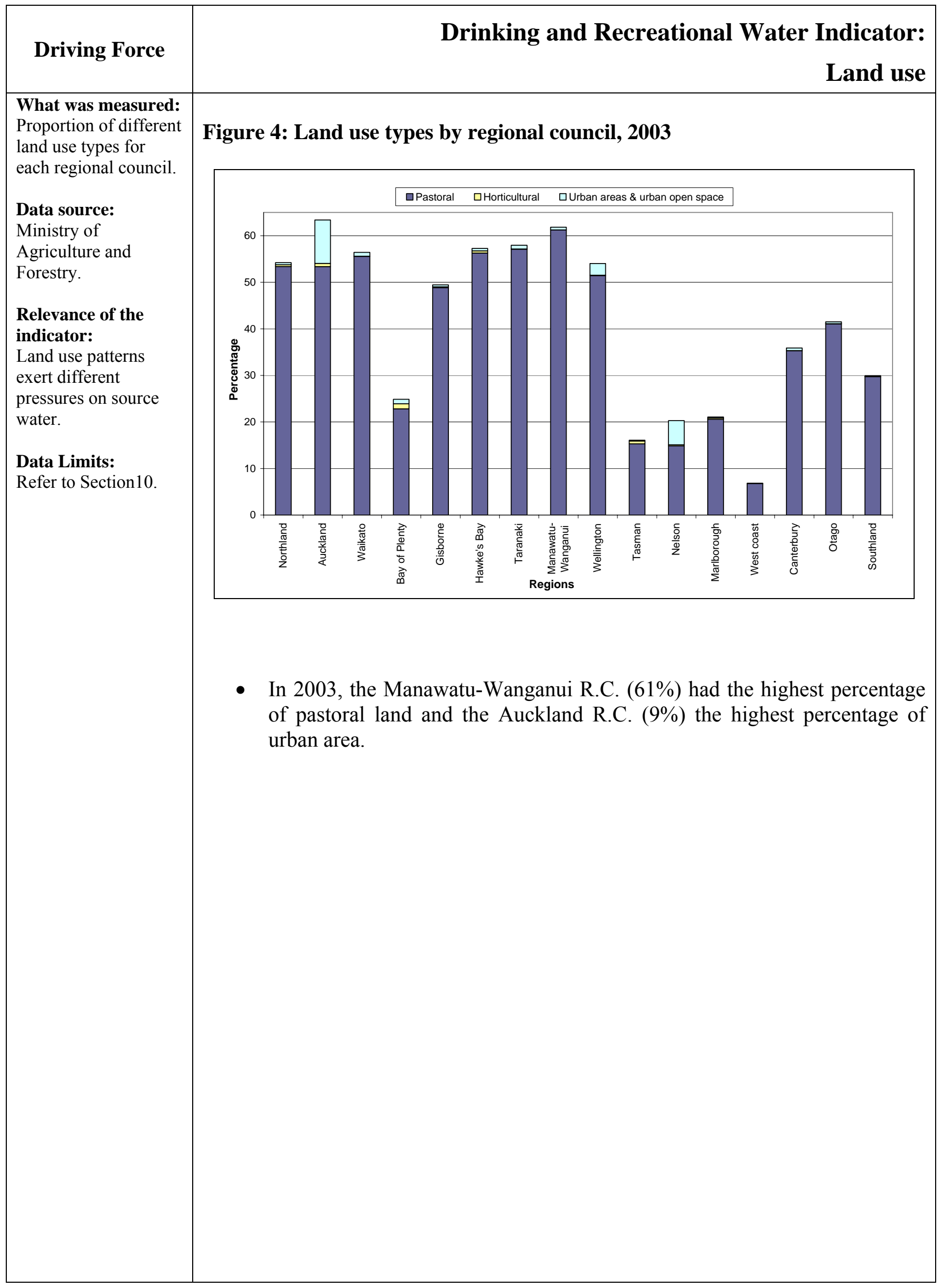




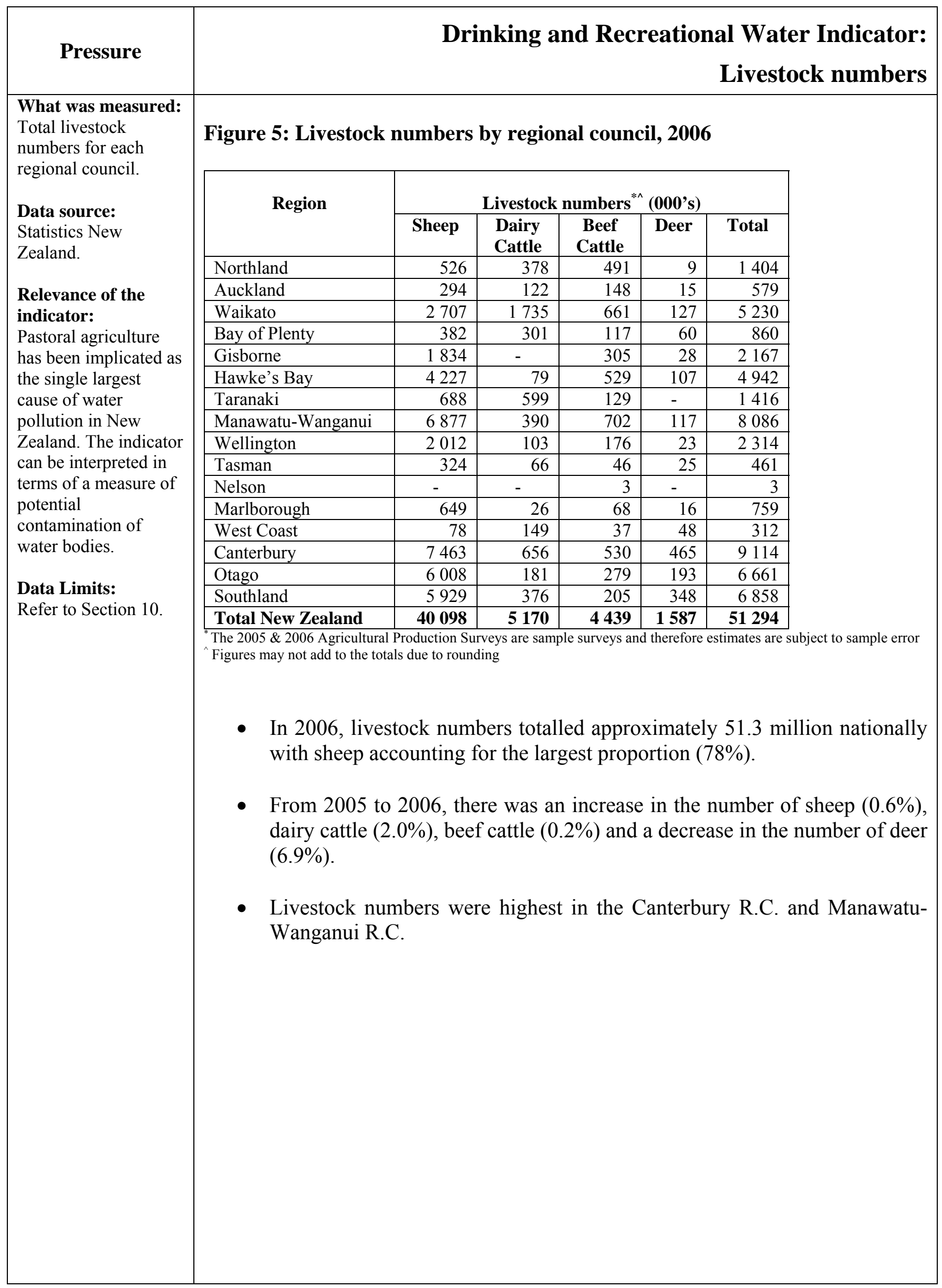




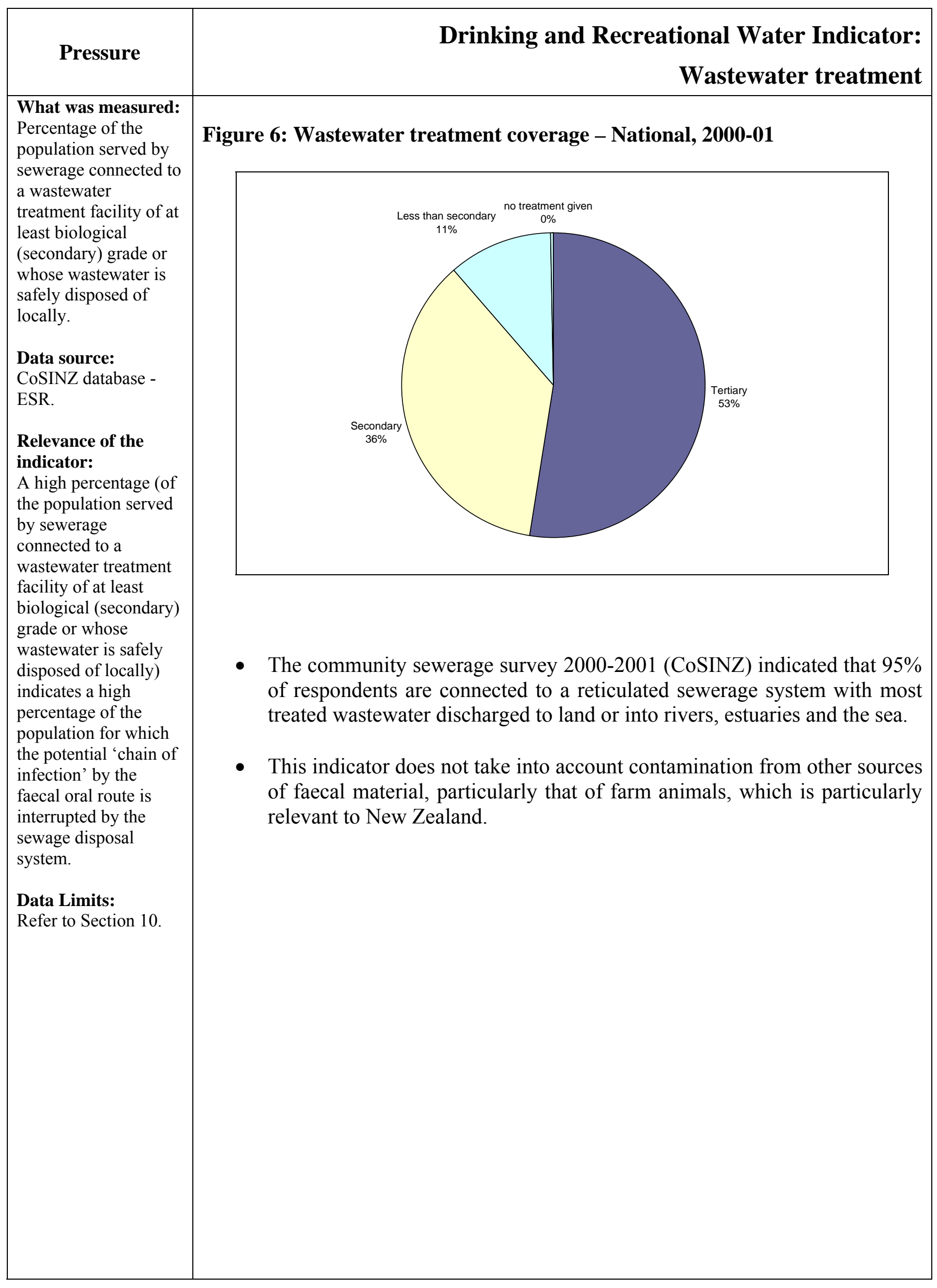




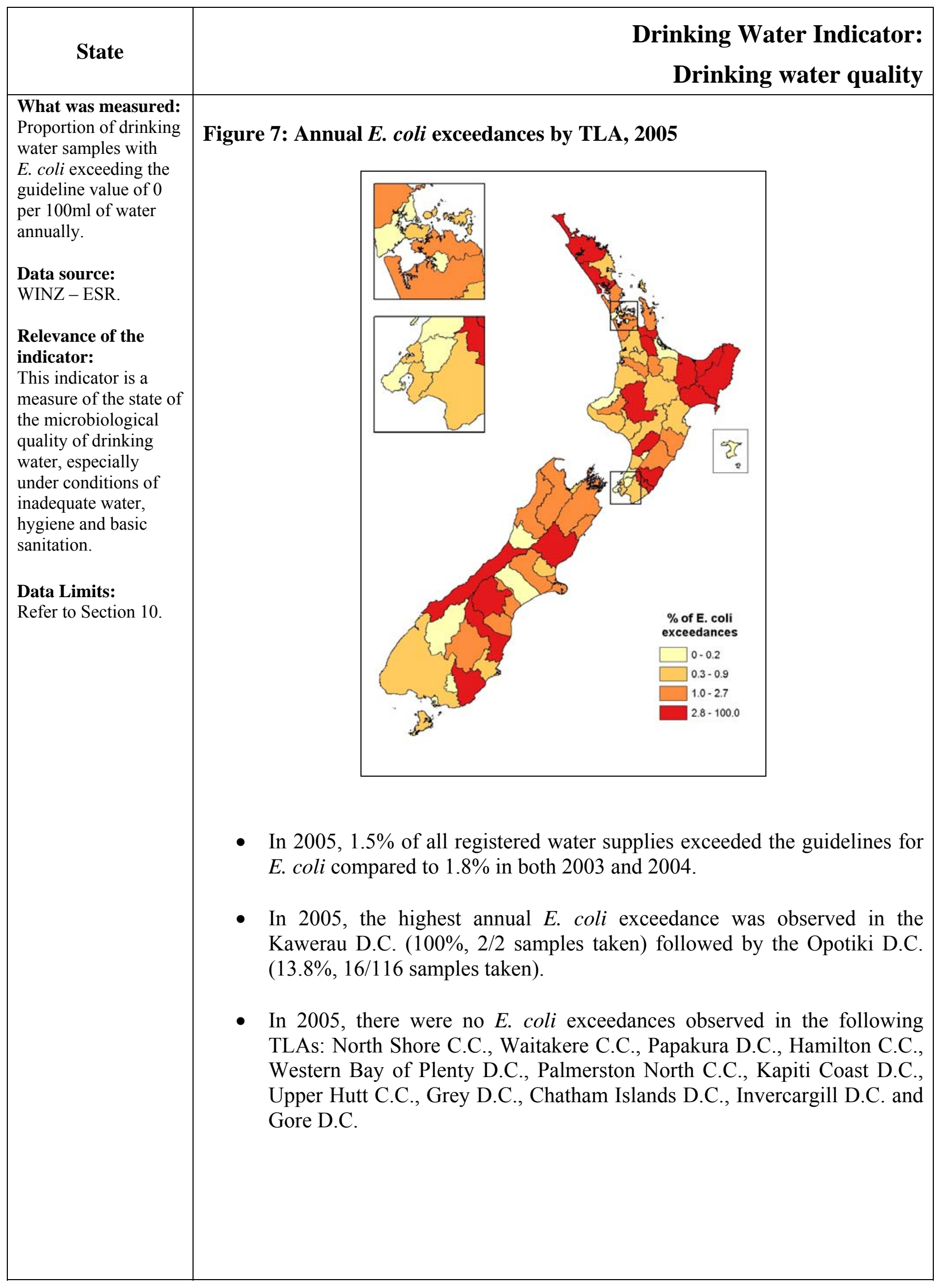




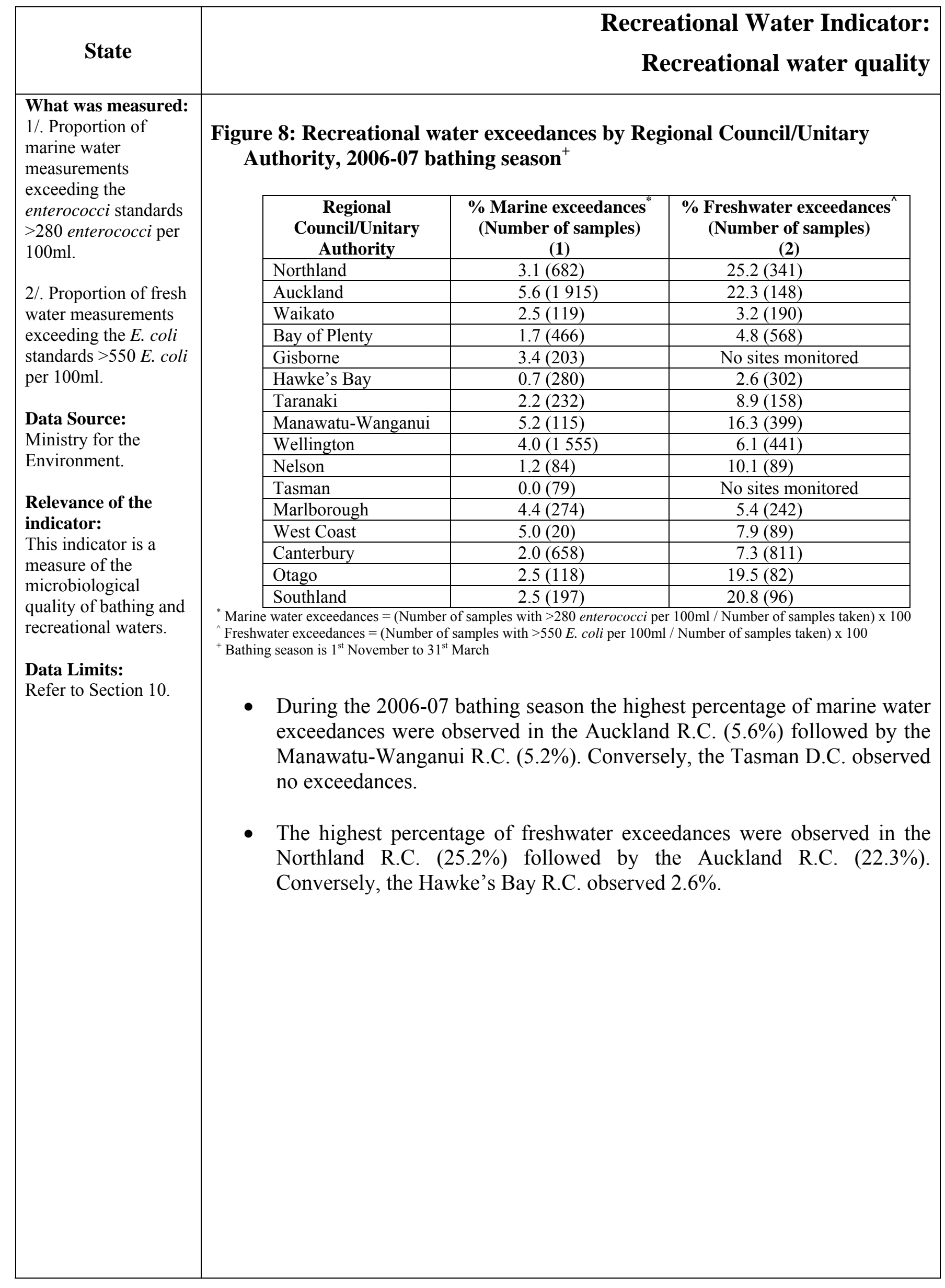




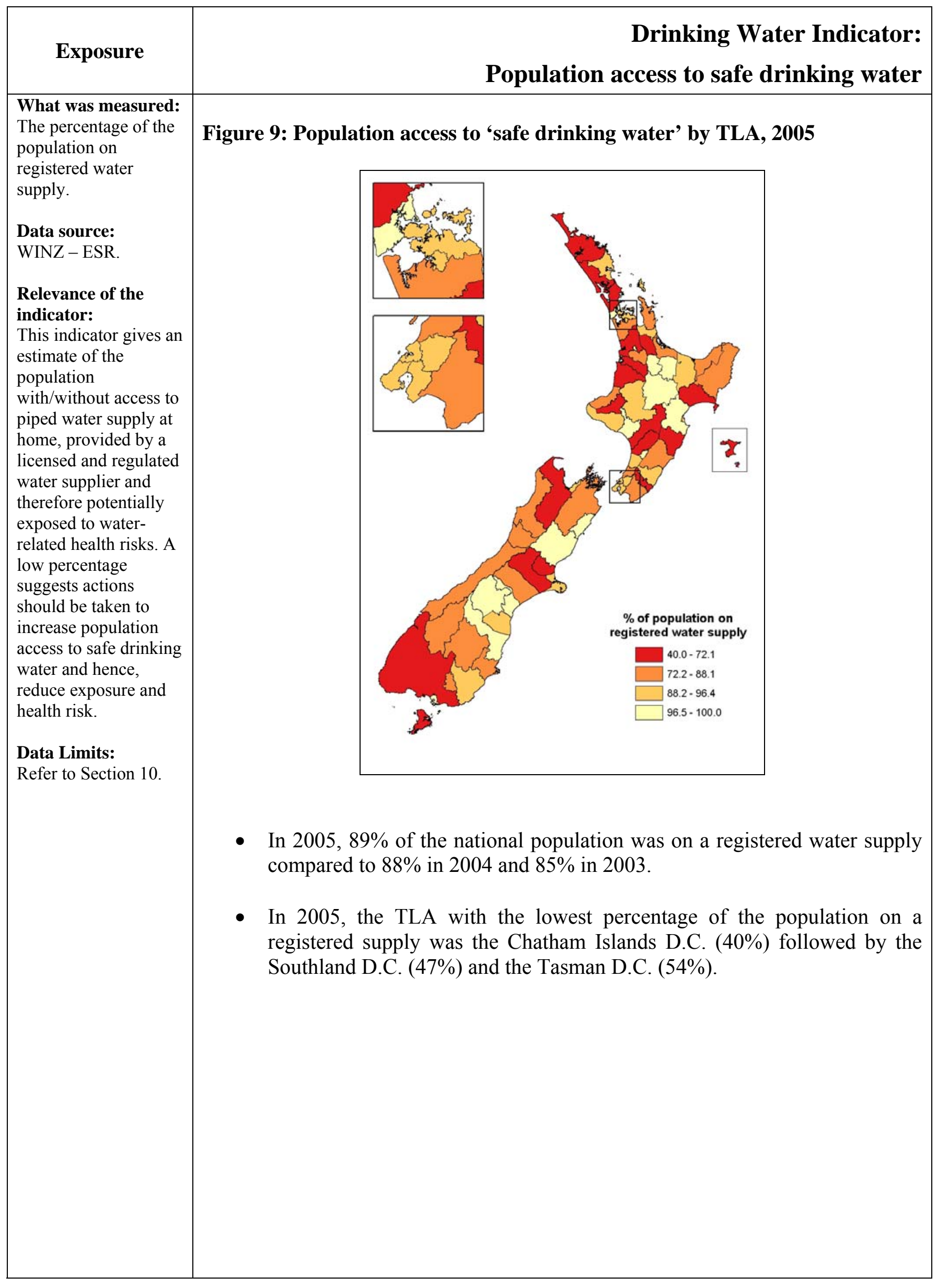




\begin{tabular}{|c|c|}
\hline Effect & $\begin{array}{l}\text { Drinking Water Indicator: } \\
\text { Drinking waterborne diseases rate }\end{array}$ \\
\hline $\begin{array}{l}\text { What was measured: } \\
\text { Annual notifications } \\
\text { (cases per } 100000 \\
\text { population) of } \\
\text { diseases, which } \\
\text { recorded drinking } \\
\text { water as a risk factor } \\
\text { of transmission and } \\
\text { had not been } \\
\text { travelling overseas } \\
\text { during the incubation } \\
\text { period. } \\
\text { Data source: } \\
\text { EpiSurv - ESR. } \\
\text { Relevance of the } \\
\text { indicator: } \\
\text { This indicator may be } \\
\text { interpreted to show } \\
\text { patterns in the } \\
\text { communicable } \\
\text { diseases rate } \\
\text { attributable to } \\
\text { drinking water. } \\
\text { Data Limits: } \\
\text { Refer to Section } 10 .\end{array}$ & 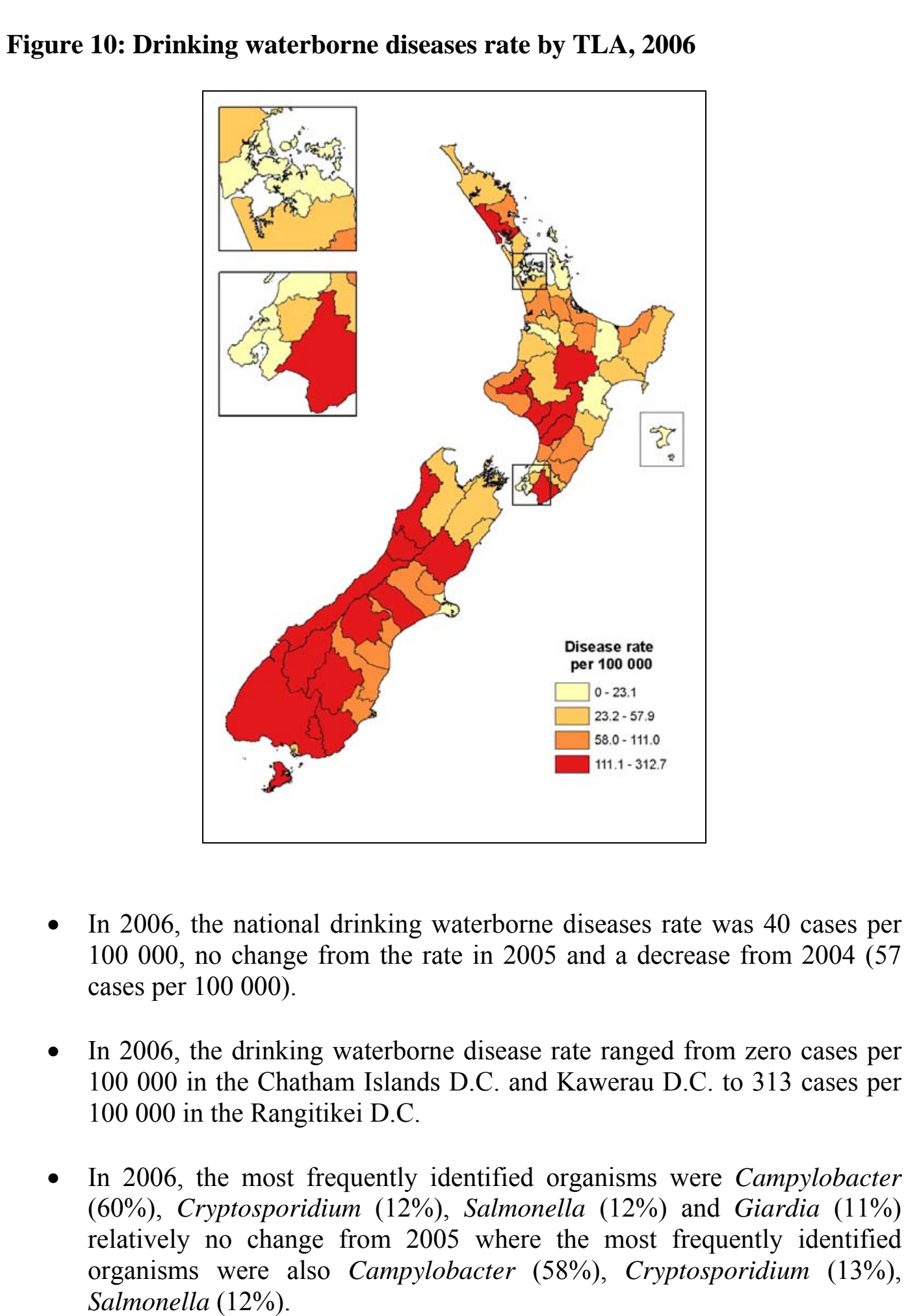 \\
\hline
\end{tabular}




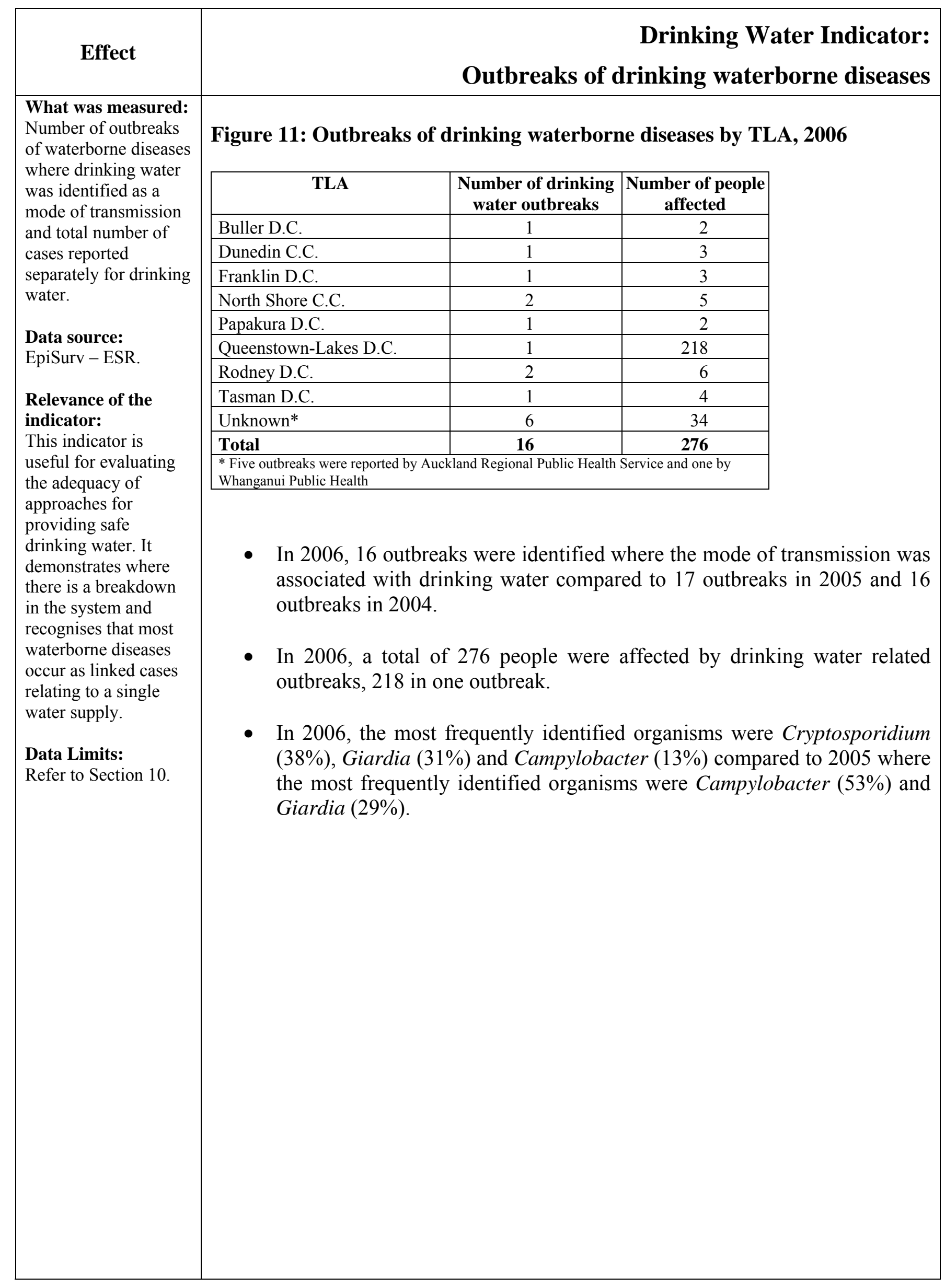




\begin{tabular}{|c|c|}
\hline Effect & $\begin{array}{l}\text { Recreational Water Quality Indicator: } \\
\text { Recreational waterborne diseases rate }\end{array}$ \\
\hline $\begin{array}{l}\text { What was measured: } \\
\text { Annual notifications } \\
\text { (cases per } 100000 \\
\text { population) of } \\
\text { diseases, which } \\
\text { recorded recreational } \\
\text { water exposure } \\
\text { (excludes swimming } \\
\text { and spa pools) as a } \\
\text { risk factor of } \\
\text { transmission. } \\
\text { Data Source: } \\
\text { EpiSurv - ESR. } \\
\text { Relevance of the } \\
\text { indicator: } \\
\text { This indicator may be } \\
\text { interpreted to show } \\
\text { trends in } \\
\text { communicable disease } \\
\text { rate attributable to } \\
\text { recreational water. } \\
\text { Data Limits: } \\
\text { Refer to Section } 10 .\end{array}$ & $\begin{array}{l}\text { - In 2006, the national recreational waterborne disease rate was } 8 \text { cases per } \\
\text { 100 000, compared to } 9 \text { cases per } 100000 \text { in } 2005 \text { and } 6 \text { cases per } 100 \text { 000 } \\
\text { in 2004. } \\
\text { Recreational waterborne disease rates by TLA ranged from zero cases to } \\
\text { 105 cases per } 100 \text { 000. } \\
\text { Mackenzie D.C. had the highest rate with } 105 \text { cases per } 100 \text { 000 followed } \\
\text { by the Queenstown-Lakes D.C. with } 96 \text { cases per } 100 \text { 000. } \\
\text { In 2006, the most frequently identified organisms were Campylobacter } \\
\text { (64\%), Salmonella (15\%), Giardia (9\%) and Cryptosporidium ( } 7 \% \text { ) } \\
\text { compared to 2005 where the most frequently identified organisms were } \\
\text { Campylobacter (61\%), Giardia (13\%), Salmonella (11\%), and } \\
\text { Cryptosporidium (10\%). }\end{array}$ \\
\hline
\end{tabular}




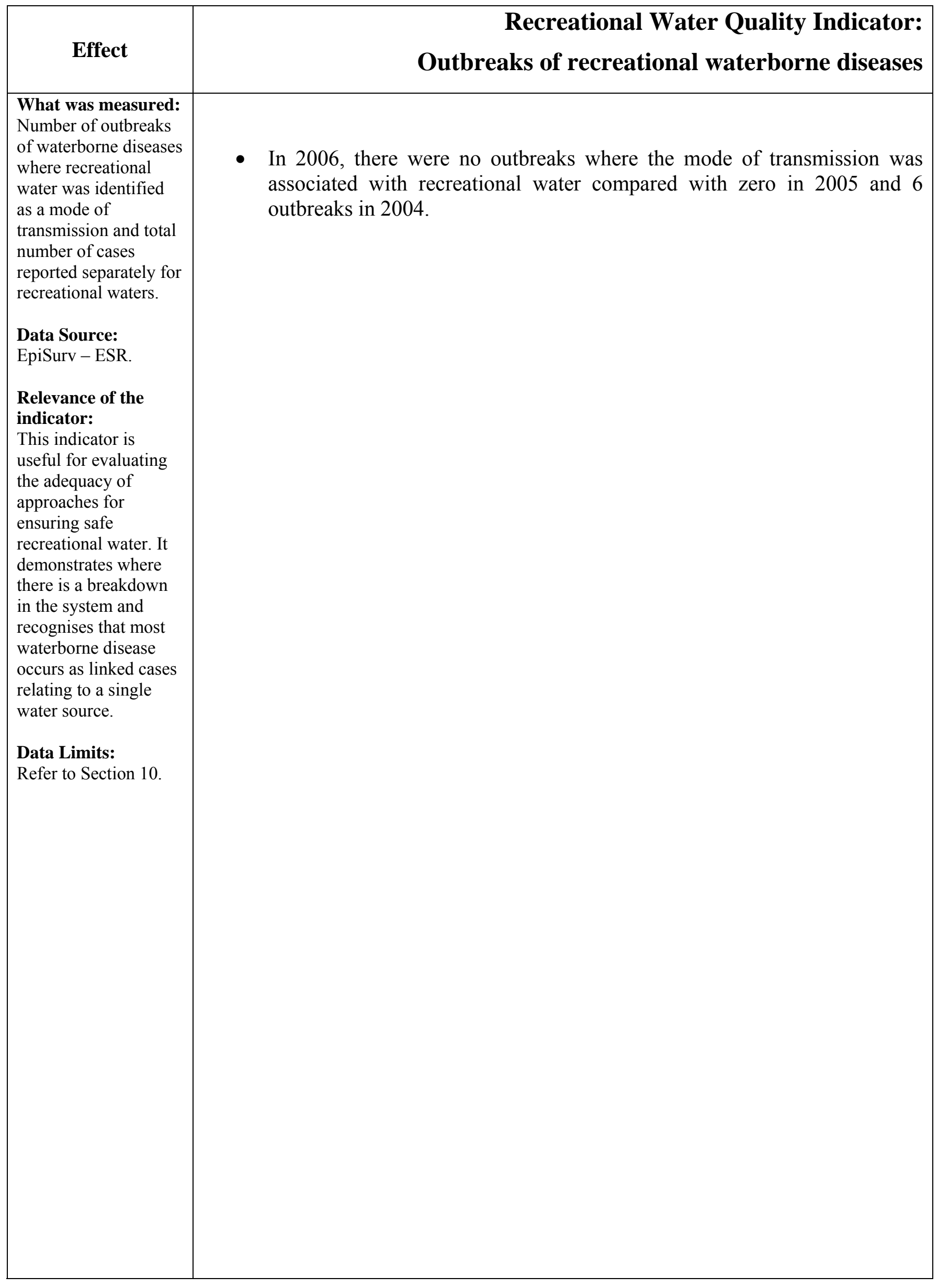




\subsection{Actions to reduce the burden of disease from poor water quality}

Actions can be at a local, regional or national level. Actions such as the introduction of the MoH's 'The Health (Drinking Water) Amendment Bill', non regulatory interventions in drinking water management practice such as the 'Drinking Water Assistance Package' and the introduction of the 'National environmental standard for sources of human drinking-water' may have an effect on both drinking water quality and disease rate. The effect of these actions could be quantified and assessed by comparing the environmental and health indicators before and after legislation is enacted. This could also be applied to any major works to upgrade water treatment plants as well as to improve source water.

Another use of action indicators is to assess and identify good practices. This would enable the identification of what actions worked, where and why. An example could be the number of resource consents (including discharge permits) approved by a regional or unitary council, along with the quantity of contaminants being discharged into the environment and their associated cumulative effects on water quality.

For communities, action indicators would be more useful if they reflected the utility of that resource to the local community, e.g. the number of times beaches were closed for bathing or shell fish gathering or the number and duration of water boiling notices. 


\section{AIR QUALITY}

\section{Figure 13: DPSEEA Framework: Air Quality Indicators}

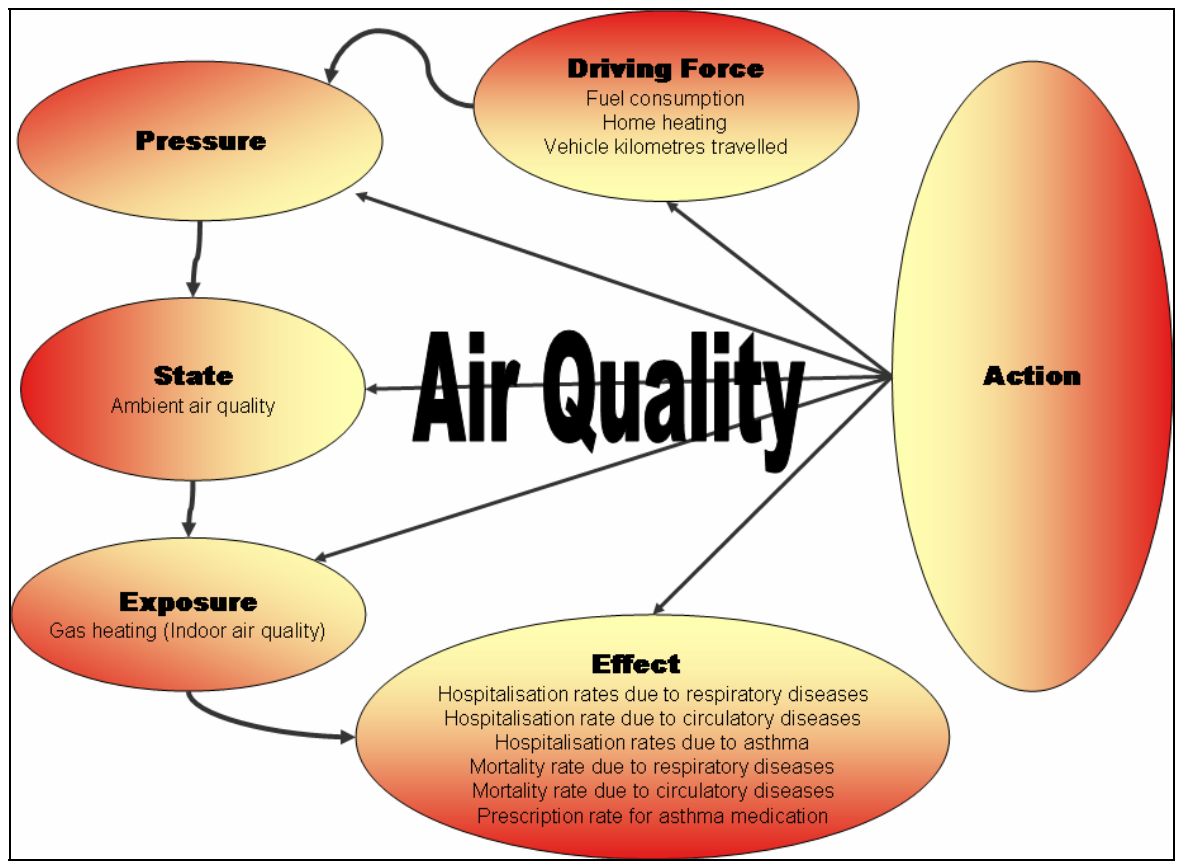

Air pollutants from motor vehicles, industry, housing and commercial sources have an adverse effect on human health and there is evidence that air pollution in many cities is responsible for a significant burden of disease and deaths (World Health Organization 2003; Pope, Dockery et al. 1991; Spix, Anderson et al. 1998; Pope, Burnett et al. 2002).

The estimated annual global burden of disease attributable to urban air pollution is 13 deaths per 100000 inhabitants and 7865000 Disability Adjusted Life Years (DALYs) or 128 DALYs per 100000 population globally (World Health Organization 2000). Estimates from the WHO indicate that air pollution alone accounts for a decreased life expectancy in European urban areas by one year or more (World Health Organization 2004b).

Epidemiological evidence shows that various health effects are causally associated with air pollution. Thus there is a "chain of causality" that links our dependence on high-energy consumption, motorised transport, fires etc with pollutant emissions, ambient air pollution and health impacts. The core set of indicators above illustrates their places in this pathway (Figure $13)$.

It should be noted that there are linkages between some of the air quality and road transport indicators, in particular the driving force indicators.

\subsection{Driving forces influencing ambient air quality \\ - Fuel consumption (Figures $14 \& 15$ ). \\ - Home heating (Figure 16). \\ - Vehicle kilometres travelled (Figure 17).}

There are a number of driving forces that impact on the quality of ambient air. Increasing demand on total annual energy consumption is considered one of the main driving forces leading to pressures on the environment. This is from energy production, which in itself is the major source for a number of pollutants emitted into the atmosphere annually (Figures 14 \& 
15). Other driving forces include wood and coal burning on open fires and in burners (Figure 16) and the number of vehicle kilometres travelled (Figure 17), both of these represent significant sources of air pollution. In some New Zealand cities, wood and coal burning and/or vehicle emissions have been identified as major sources of air pollution.

\subsection{Pressures on ambient air quality}

Emissions of a selection of pollutants or precursors of pollutants constitute a potential risk to health. Some pollutants are directly emitted into the atmosphere, e.g. $\mathrm{SO}_{2}$ from a variety of sources such as vehicles, construction sites, agricultural etc. Other pollutants are formed by chemical reactions in the atmosphere (such as secondary PM and $\mathrm{O}_{3}$ as a result of fuel combustion in motor vehicles, at power plants, and in other industrial processes. In general terms, a change in the temporal and spatial variation in emission sources will lead to a change in ambient air concentrations. However, ambient air concentrations are also influenced by meteorological conditions. Changes in air pollution concentrations may lead to a change in exposures and consequent health risk to the population. Some of the pollutants described here have long atmospheric lifetimes and may therefore have the potential to be transported over long distances.

\subsection{State of ambient air quality \\ - Ambient air quality (Figure 18).}

Pollutants of interest for air quality include particulate matter (PM), $\mathrm{O}_{3}, \mathrm{SO}_{2}, \mathrm{NOx}$, and $\mathrm{CO}$. Measurements of the ambient concentrations of these pollutants provide a good picture of air quality and related health risk (Figure 18).

\subsection{Exposures to ambient and indoor air quality \\ - Gas heating (Figure 19).}

\section{Indoor}

There are many sources of indoor air pollution in homes primarily from combustion sources such as oil, gas, kerosene, coal, wood and second hand tobacco smoke. Combined with inadequate ventilation an increase in indoor air pollution levels will be observed. The use of unvented or defective vented combustion appliances such as gas heaters to warm dwellings is a potential source of exposure to poor quality indoor air (Figure 19). $\mathrm{CO}$ and $\mathrm{NO}_{2}$ are toxic gases and major pollutants produced by gas heating appliances. This is of particular importance for unflued appliances. These appliances also produce a lot of water vapour leading to a potential vector for moulds. $\mathrm{CO}$ and $\mathrm{NO}_{2}$ are associated with both immediate and long term health effects. Exposure to $\mathrm{CO}$ is associated with adverse health effects including fatigue, flu-like symptoms, angina, impaired vision and reduced brain function. Immediate health effects from exposure to $\mathrm{NO}_{2}$ included eye, nose and throat irritation, impaired lung function and increased respiratory infections especially in young children while long term health effects include respiratory diseases, heart disease and cancer (United States Environmental Protection Agency 2006).

\section{Ambient}

Airsheds are populated areas that are known, or have the potential, to breach an air quality standard identified in the Resource Management (National Environmental Standards Relating to Certain Air Pollutants, Dioxins and Other Toxics) Regulations 2004. They have been identified based on regional councils and unitary authorities' knowledge of existing air quality data and the location of significant sources and factors that affect the spread of air pollution such as local 
geography and weather (Ministry for the Environment 2007). These airsheds will assist in air quality reporting and the assessment of regional exposure to air pollutants.

\subsection{Health effects associated with poor ambient and indoor air quality \\ - Hospitalisation rate due to respiratory diseases (Figure 20). \\ - Hospitalisation rate due to circulatory diseases (Figure 21). \\ - Hospitalisation rate due to asthma (Figure 22). \\ - Mortality rate due to respiratory diseases (Figure 23). \\ - Mortality rate due to circulatory diseases (Figure 24). \\ - Prescription rate for asthma medication (Figure 25).}

There is increasing evidence for adverse effects of air pollution on respiratory and cardiovascular systems from both acute and chronic exposure to air pollutants, ranging from transient changes in respiratory function, to hospital admissions and death (Figures 20 to 25).

The most severe effects include a significant reduction in life expectancy due to long-term exposure to high levels of $\mathrm{PM}_{10}$. Determining a threshold of $\mathrm{PM}_{10}$ for health effects remains elusive at a population level because there are inevitably large differences in individual susceptibilities in large populations. The majority of evidence demonstrates that there is no safe level or threshold of exposure to particulate matter in air pollution, especially with regard to very fine particles (less than $2.5 \mu \mathrm{m}$ in diameter). Increased mortality (all-cause, cardiovascular and respiratory) have been shown to increase with higher concentrations of particulate matter in separate studies of 20 United States cities (Samet, Domenici et al. 2000), Sao Paulo (Gouveia \& Fletcher 2000), Brisbane (Simpson, Williams et al. 1997) and Santiago (Salinas \& Vega 1995). In a global estimate of health effects caused by particulate air pollution, Cohen, Ross et al. (2005) estimated that 800000 premature deaths occur annually across the globe from $\mathrm{PM}_{2.5}$ exposure alone. Instead of thresholds, exposure, concentration, and response relationships for different health endpoints provide more realistic information for action. 


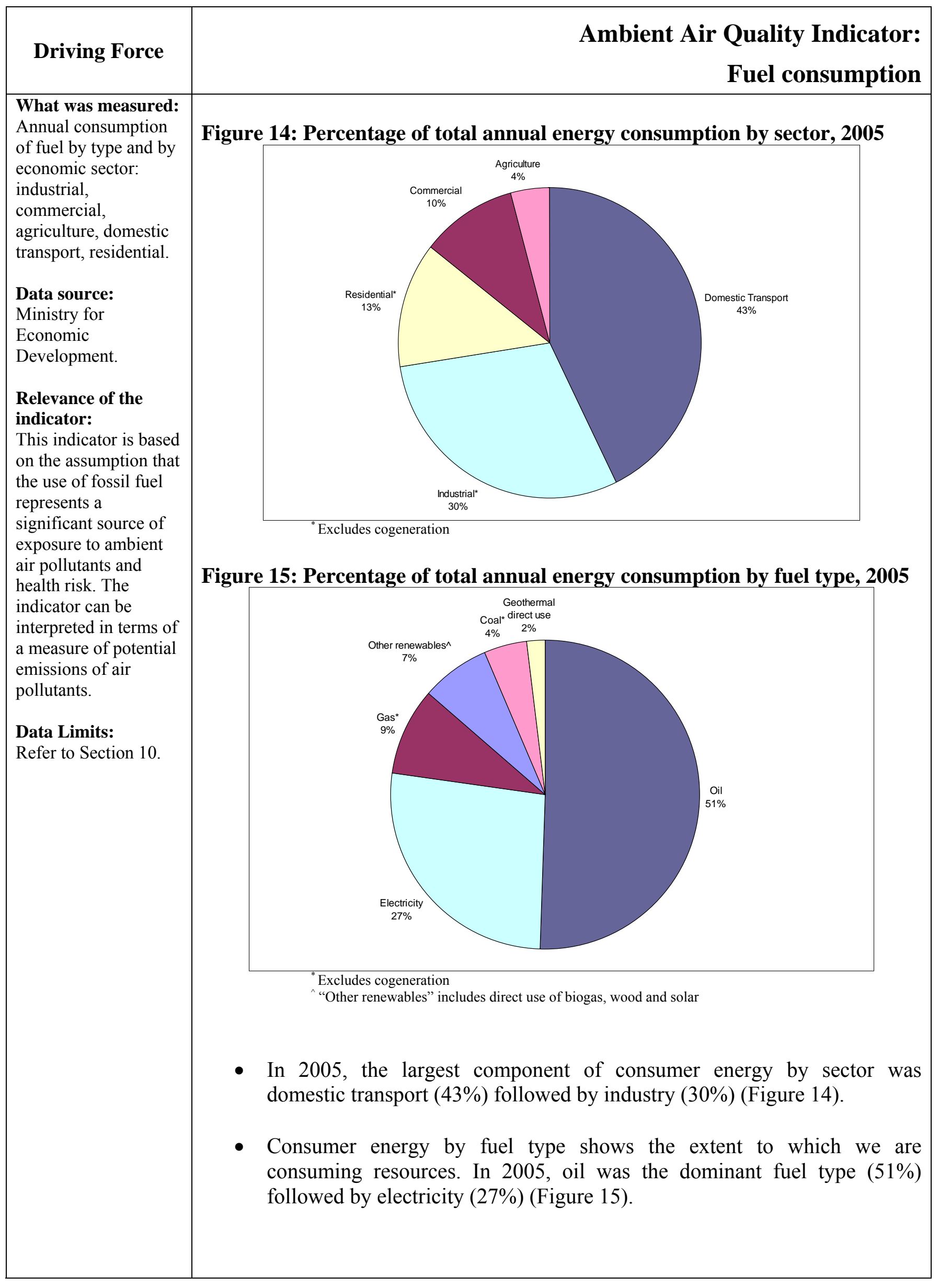




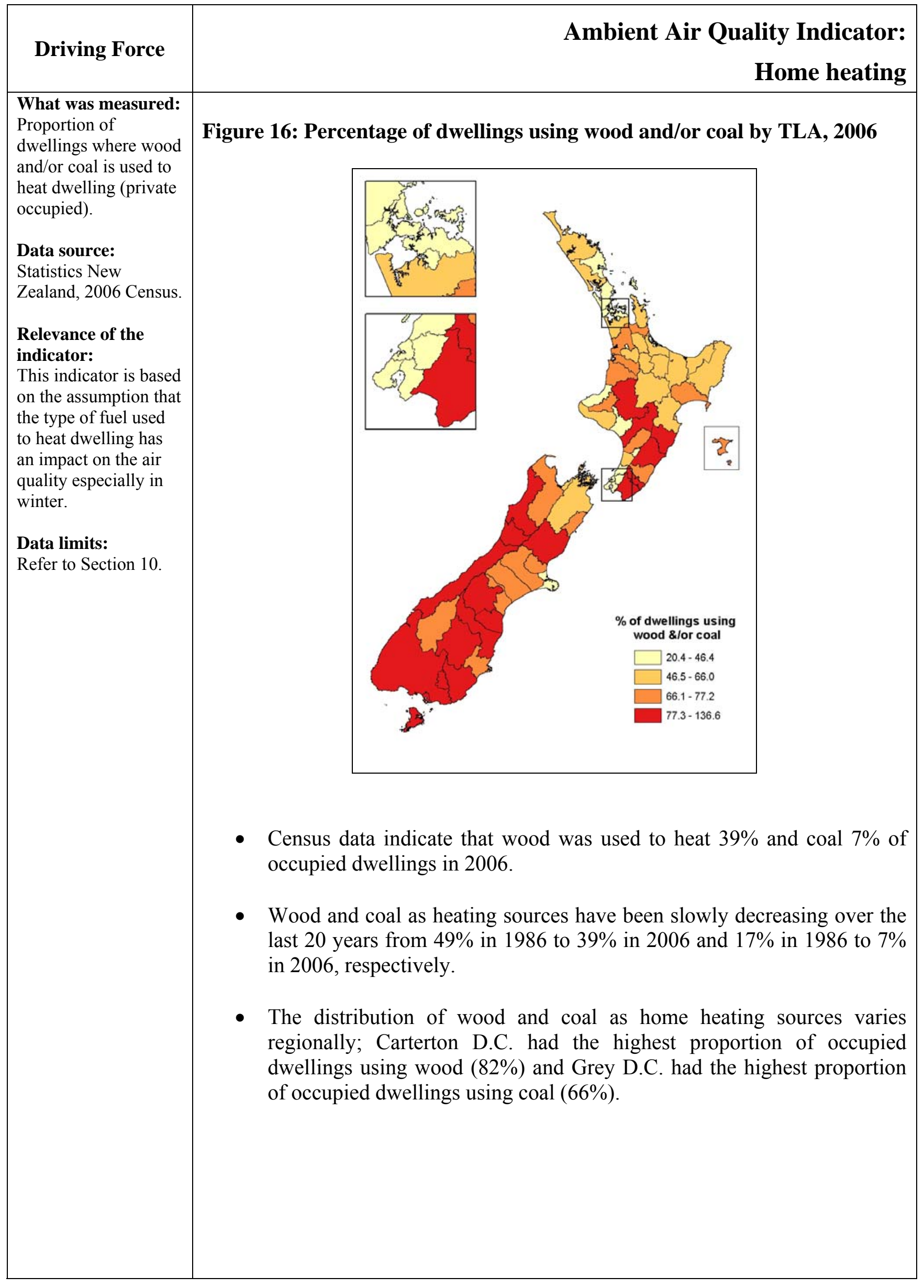




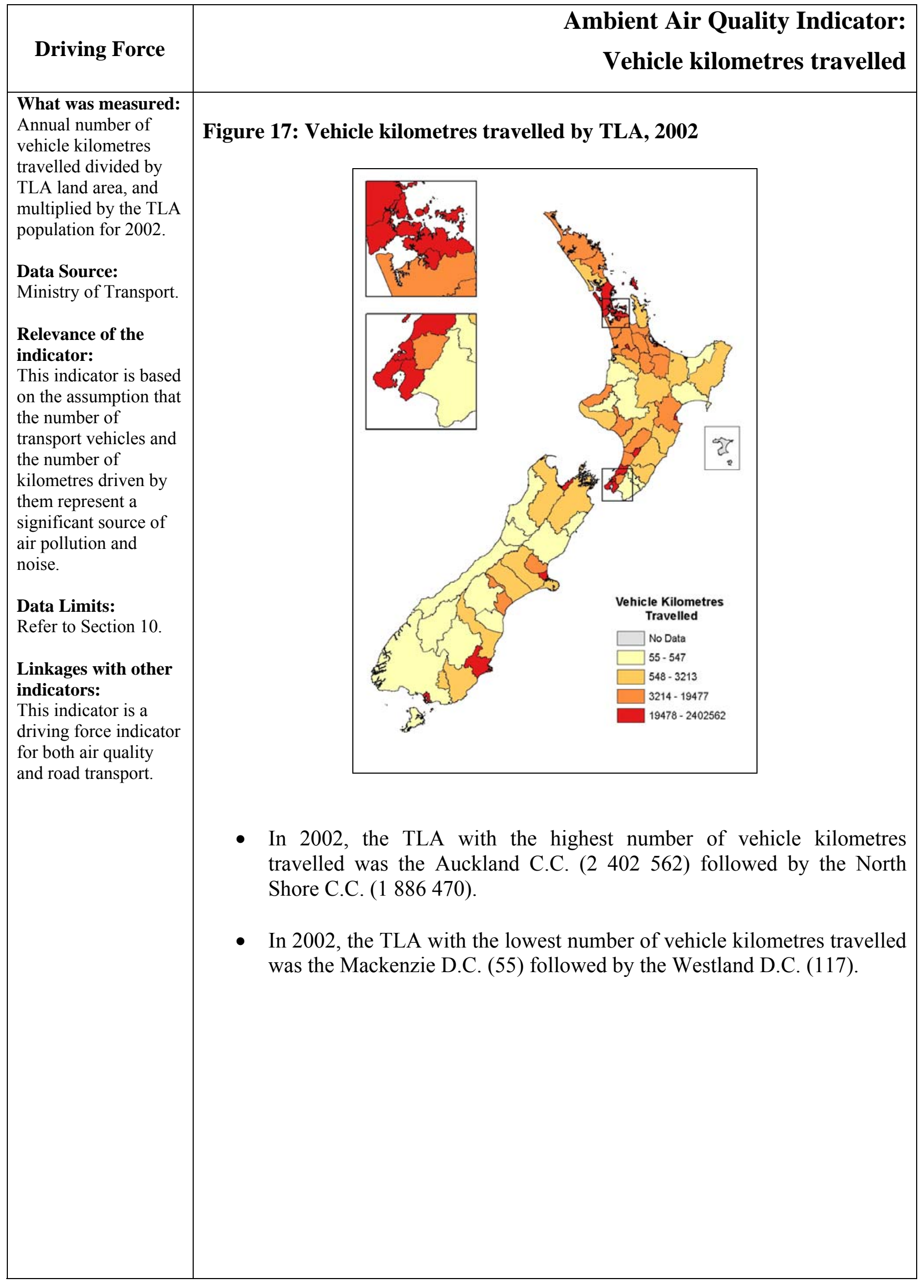




\begin{tabular}{|c|c|c|c|c|}
\hline State & & & \multicolumn{2}{|c|}{$\begin{array}{r}\text { Ambient Air Quality Indicator: } \\
\text { Ambient air quality }\end{array}$} \\
\hline \multirow{26}{*}{$\begin{array}{l}\text { What was measured: } \\
\text { Number of days } \\
\text { exceeding WHO } \\
\text { guidelines for } \mathrm{PM}_{10} \\
\left(>50 \mu \mathrm{g} / \mathrm{m}^{3}\right) \text {. } \\
\text { Data sources: } \\
\text { Ministry for the } \\
\text { Environment. } \\
\text { Relevance of the } \\
\text { indicator: } \\
\text { This indicator is based } \\
\text { on the assumption that } \\
\text { ambient levels of air } \\
\text { pollution represent a } \\
\text { significant source of } \\
\text { exposure and health } \\
\text { risk. } \mathrm{NO}_{2}, \mathrm{PM} \mathrm{M}_{10}, \mathrm{SO} \mathrm{O}_{2,} \\
\mathrm{CO} \text { and } \mathrm{O}_{3} \text { give a } \\
\text { good picture of } \\
\text { ambient } \\
\text { concentrations in } \\
\text { cities and are related } \\
\text { to health effects. It is } \\
\text { based on the } \\
\text { assumption that an } \\
\text { increase of the } \\
\text { incidence of health } \\
\text { outcomes to a given } \\
\text { population is linearly } \\
\text { proportional to the } \\
\text { pollutant } \\
\text { concentration. }\end{array}$} & \multicolumn{4}{|c|}{ Figure 18: $\mathbf{P M}_{10}$ exceedances by airshed, 2005} \\
\hline & $\begin{array}{c}\text { Regional } \\
\text { Council/Unitary } \\
\text { Authority }\end{array}$ & Airshed & $\begin{array}{c}\text { Highest 24hr } \\
\text { measurement } \\
\left(\mu \mathrm{g} / \mathrm{m}^{3}\right)\end{array}$ & $\begin{array}{c}\text { Number of } \\
\text { exceedances } \\
>50 \mu g / \mathbf{m}^{3}\end{array}$ \\
\hline & Northland & Kaitia & 41 & 0 \\
\hline & Northland & Whangarei & 47 & 0 \\
\hline & Auckland & Auckland & 86 & 4 \\
\hline & Waikato & Hamilton & 37 & 0 \\
\hline & Waikato & Matamata & 36 & 0 \\
\hline & Waikato & Te Kuiti & 54 & 2 \\
\hline & Waikato & Tokoroa & 89 & 33 \\
\hline & Waikato & Taupo & 45 & 1 \\
\hline & Bay of Plenty & Rotorua & 54 & 2 \\
\hline & Hawke's Bay & Napier & 67 & 4 \\
\hline & Hawke's Bay & Hastings & 145 & 18 \\
\hline & Wellington & Upper Hutt & 23 & 0 \\
\hline & Wellington & Lower Hutt & 41 & 0 \\
\hline & Wellington & Wellington City & 30 & 0 \\
\hline & Wellington & Wainuiomata & 28 & 0 \\
\hline & Wellington & Wairarapa & 61 & 1 \\
\hline & Nelson & Nelson South & 96 & 51 \\
\hline & Nelson & Tahunanui & 81 & 18 \\
\hline & Tasman & Richmond & 84 & 34 \\
\hline & Marlborough & Blenheim & 58 & 3 \\
\hline & Canterbury & Rangiora & 99 & 10 \\
\hline & Canterbury & Kaiapoi & 152 & 17 \\
\hline & Canterbury & Christchurch & 154 & 39 \\
\hline & Canterbury & Ashburton & 89 & 18 \\
\hline Data L imitc. & Canterbury & Timaru & 109 & 47 \\
\hline $\begin{array}{l}\text { Data Limits: } \\
\text { Refer to Section }\end{array}$ & Otago & Alexandra & 103 & 42 \\
\hline & Otago & Mosgiel & 98 & 11 \\
\hline & Otago & Dunedin & 52 & 1 \\
\hline & Southland & Invercargill & 198 & 5 \\
\hline & $\begin{array}{l}\text { The following airsheds h, } \\
\text { Kapiti, Porirua, Karori, } \\
\text { Wanaka and Hawea), Go } \\
\text { - In 2005, } \\
\text { Nelson S }\end{array}$ & $\begin{array}{l}\text { Ino data for 2005: Ker } \\
\text { lson C, Reefton, Geral } \\
\text { Urban. } \\
\text { he greatest nul } \\
\text { uth airshed ( } 51\end{array}$ & $\begin{array}{l}\text { gaville, Marsden Poi } \\
\text { mate, Otago Airshed } \\
\text { of } \mathrm{PM}_{10} \text { excee } \\
\text { wed by the Tir }\end{array}$ & $\begin{array}{l}\text { Hauraki Plains, Taumaranui, Taihape, } \\
\text { (made up of Kingston, Queenstown, } \\
\text { ances were reported in the } \\
\text { aru airshed (47). }\end{array}$ \\
\hline
\end{tabular}




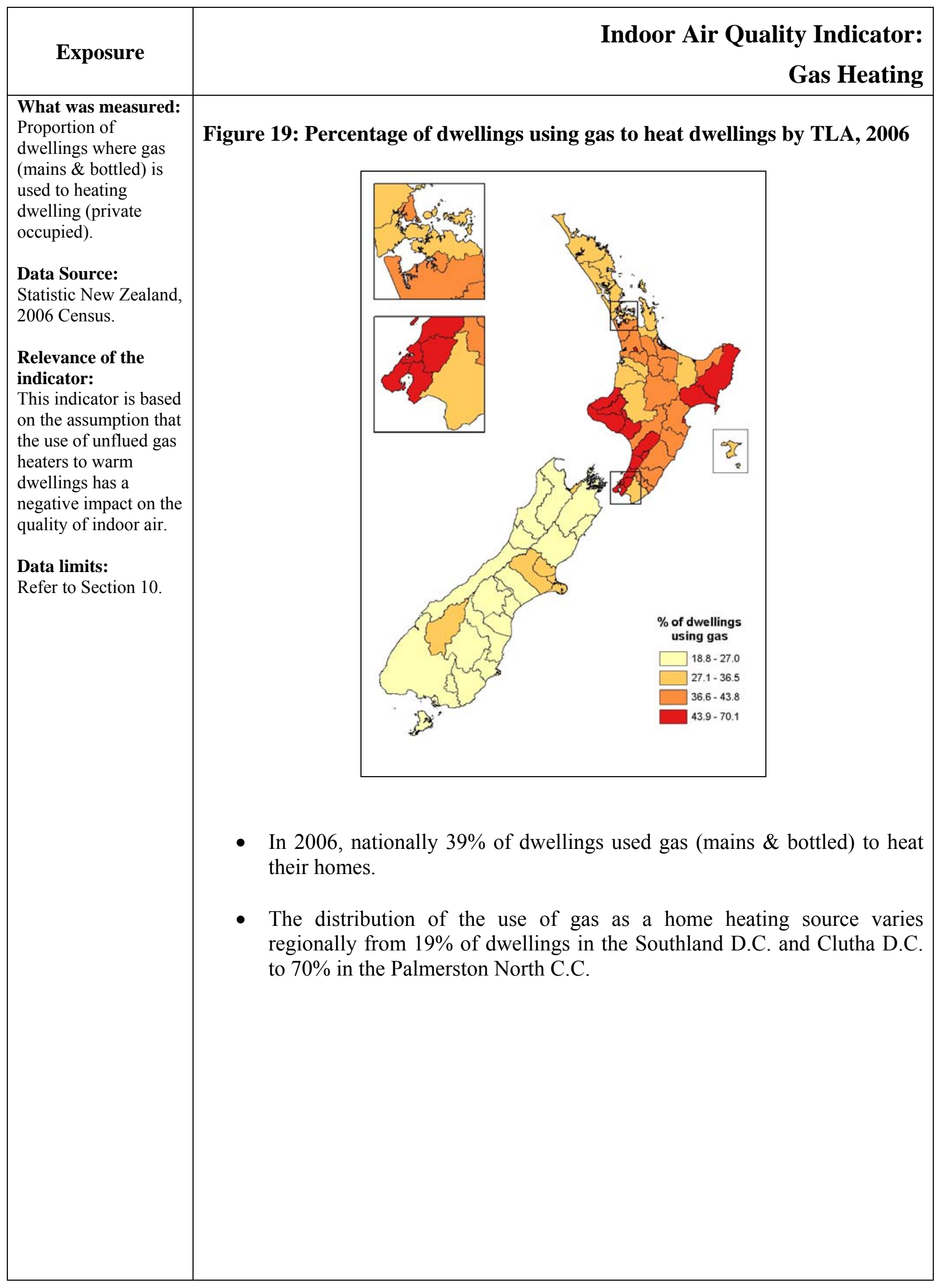




\begin{tabular}{|c|c|}
\hline Effect & $\begin{array}{r}\text { Air Quality Indicator: } \\
\text { Hospital admissions for respiratory diseases }\end{array}$ \\
\hline $\begin{array}{l}\text { What was measured: } \\
\text { Annual number of } \\
\text { hospital admissions } \\
\text { for respiratory } \\
\text { diseases (ICD } 10 \\
\text { codes J00-J99) per } \\
100000 \text { population. } \\
\text { Data Source: } \\
\text { NZHIS } \\
\text { Relevance of the } \\
\text { indicator: } \\
\text { This indicator may be } \\
\text { interpreted to show } \\
\text { trends in hospital } \\
\text { admissions as a result } \\
\text { of respiratory } \\
\text { diseases. A small part } \\
\text { of hospital admissions } \\
\text { for respiratory } \\
\text { diseases can be } \\
\text { attributed to exposure } \\
\text { to air pollution. } \\
\text { Hospital admissions } \\
\text { do not include visits } \\
\text { to the emergency } \\
\text { department and are } \\
\text { highly dependent } \\
\text { upon the effectiveness } \\
\text { of the health care } \\
\text { system. }\end{array}$ & Age standardised* rate \\
\hline $\begin{array}{l}\text { Data limits: } \\
\text { Refer to Section } 10 .\end{array}$ & $\begin{array}{l}\text { *Age standardised to the New Zealand population Census } 2006 \\
\text { - In } 2005 \text {, the national hospitalisation rate due to respiratory diseases was } \\
1433 \text { cases per } 100000 \text { compared to } 1493 \text { cases per } 100000 \text { in } 2004 \text { and } \\
1510 \text { cases per } 100000 \text { in } 2003 \text {. } \\
\text { - There was a } 7 \% \text { decrease in the age standardised }{ }^{*} \text { hospitalisation rate due } \\
\text { to respiratory diseases between } 2004 \text { and } 2005 \text {. } \\
\text { - The age standardised }{ }^{*} \text { hospitalisation rate due to respiratory diseases } \\
\text { varied from } 613 \text { cases per } 100000 \text { in the Chatham Island Territory to } \\
2417 \text { cases per } 100000 \text { in the Kawerau D.C. }\end{array}$ \\
\hline
\end{tabular}




\begin{tabular}{|c|c|}
\hline Effect & $\begin{array}{r}\text { Air Quality Indicator: } \\
\text { Hospital admissions for circulatory diseases }\end{array}$ \\
\hline $\begin{array}{l}\text { What was measured: } \\
\text { Annual number of } \\
\text { hospital admissions } \\
\text { for diseases of the } \\
\text { circulatory system } \\
\text { (ICD } 10 \text { codes I00- } \\
\text { I99) per } 100000 \\
\text { population. } \\
\text { Data Source: } \\
\text { NZHIS } \\
\text { Relevance of the } \\
\text { indicator: } \\
\text { This indicator may be } \\
\text { interpreted to show } \\
\text { trends in hospital } \\
\text { admissions as a result } \\
\text { of circulatory system } \\
\text { diseases. A small part } \\
\text { of it can be attributed } \\
\text { to exposure to air } \\
\text { pollution. Hospital } \\
\text { admissions do not } \\
\text { include visits to the } \\
\text { emergency } \\
\text { department and are } \\
\text { highly dependent } \\
\text { upon the effectiveness } \\
\text { of the health care } \\
\text { system. }\end{array}$ & 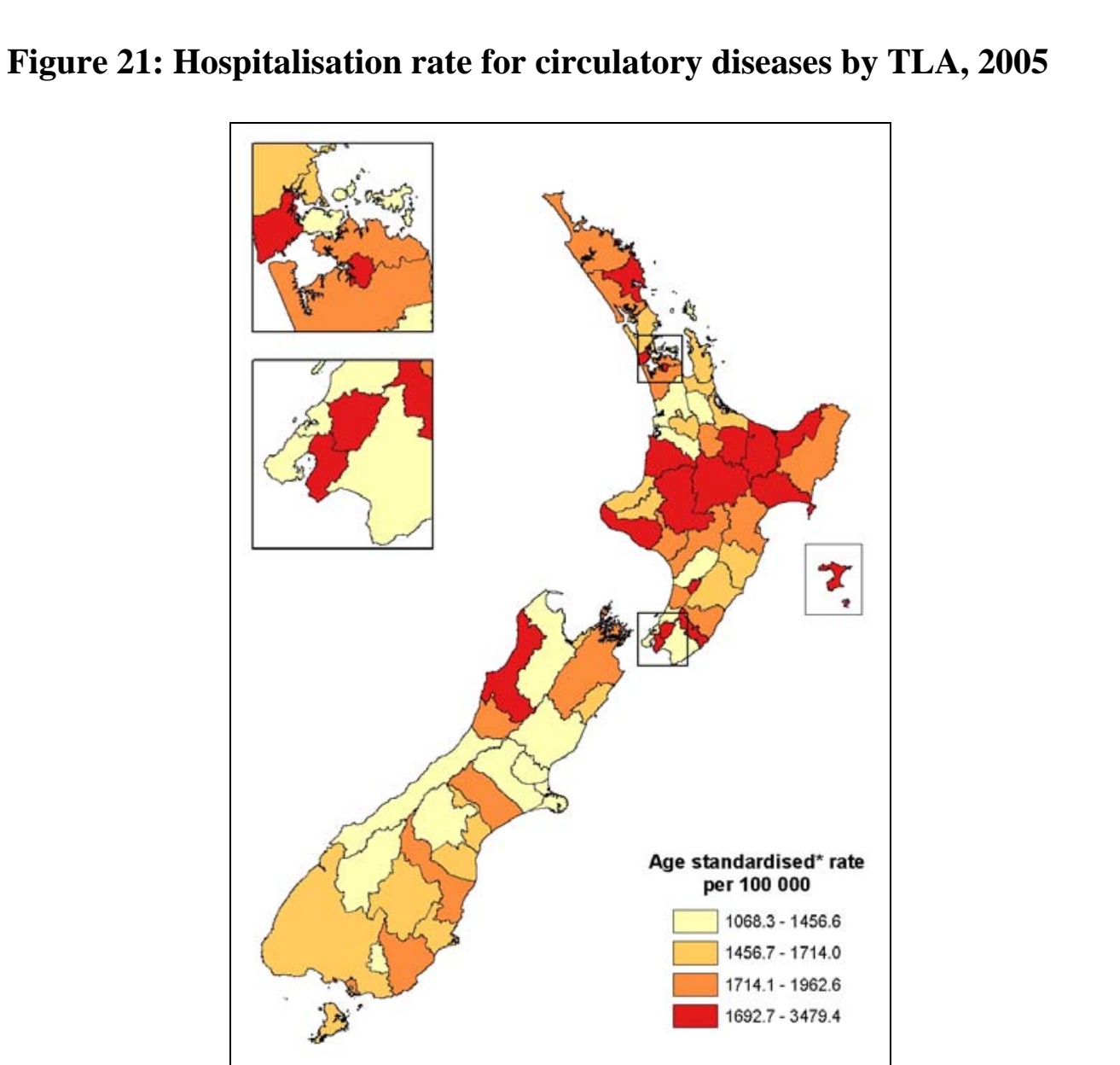 \\
\hline $\begin{array}{l}\text { Data Limits: } \\
\text { Refer to Section } 10 .\end{array}$ & $\begin{array}{l}\text { *Age standardised to the New Zealand population Census } 2006 \\
\text { - In } 2005 \text {, the national hospitalisation rate due to circulatory diseases } \\
\text { was } 1854 \text { cases per } 100000 \text { compared to } 1871 \text { cases per } 100000 \text { in } \\
2004 \text { and } 1703 \text { cases per } 100000 \text { in } 2003 \text {. } \\
\text { - There was a } 4 \% \text { decrease in the age standardised }{ }^{*} \text { hospitalisation rate } \\
\text { due to circulatory diseases between } 2004 \text { and } 2005 \text {. } \\
\text { - The age standardised hospitalisation rate due to circulatory diseases } \\
\text { varied from } 1068 \text { cases per } 100000 \text { in the Kapiti D.C. to } 3479 \text { cases } \\
\text { per } 100000 \text { in the Palmerston North C.C. }\end{array}$ \\
\hline
\end{tabular}




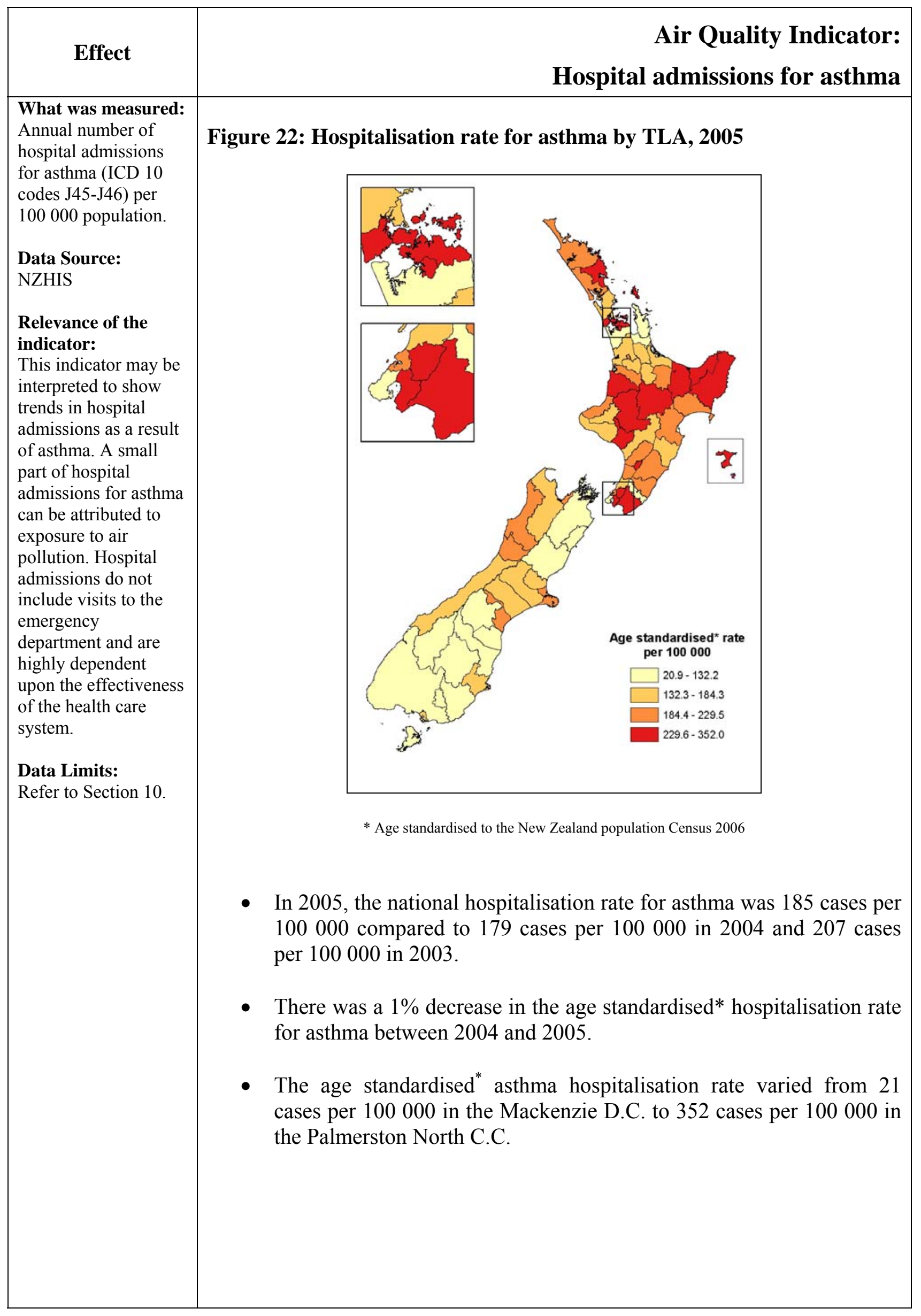




\begin{tabular}{|c|c|}
\hline Effect & $\begin{array}{r}\text { Air Quality Indicator: } \\
\text { Mortality due to respiratory diseases }\end{array}$ \\
\hline $\begin{array}{l}\text { What was measured: } \\
\text { Annual mortality rate } \\
\text { due to respiratory } \\
\text { diseases - all ages } \\
\text { (ICD } 10 \text { codes J00- } \\
\text { J99) per } 100000 \\
\text { population. } \\
\text { Data Source: } \\
\text { NZHIS } \\
\text { Relevance of the } \\
\text { indicator: } \\
\text { This indicator may be } \\
\text { interpreted to show } \\
\text { trends in mortality due } \\
\text { to respiratory diseases. } \\
\text { A small part of } \\
\text { respiratory mortality } \\
\text { can be attributed to } \\
\text { exposure to air } \\
\text { pollution. Mortality is } \\
\text { also dependent upon } \\
\text { the effectiveness of } \\
\text { the health care system. } \\
\text { Data limits: } \\
\text { Refer to Section } 10 .\end{array}$ & 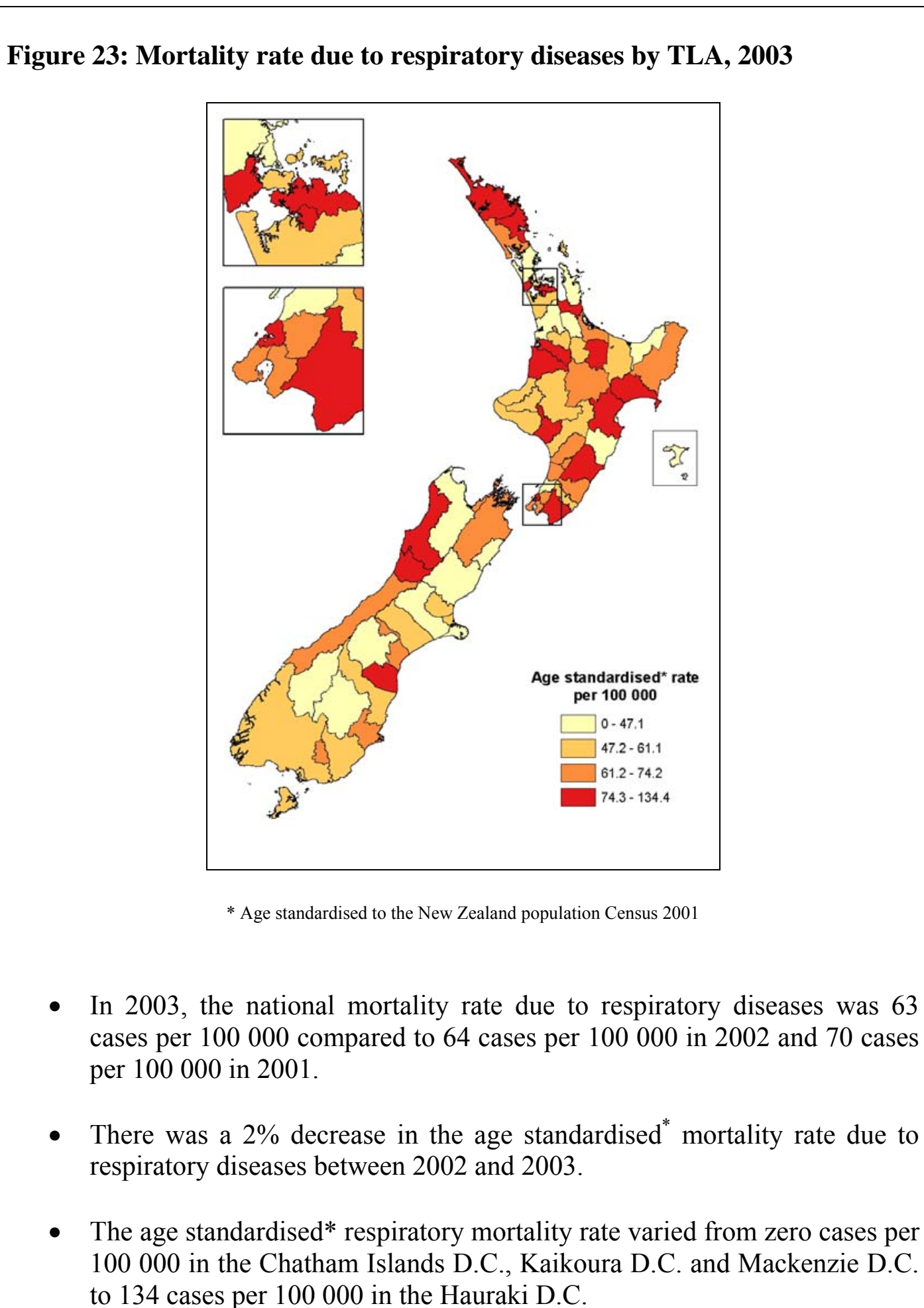 \\
\hline
\end{tabular}




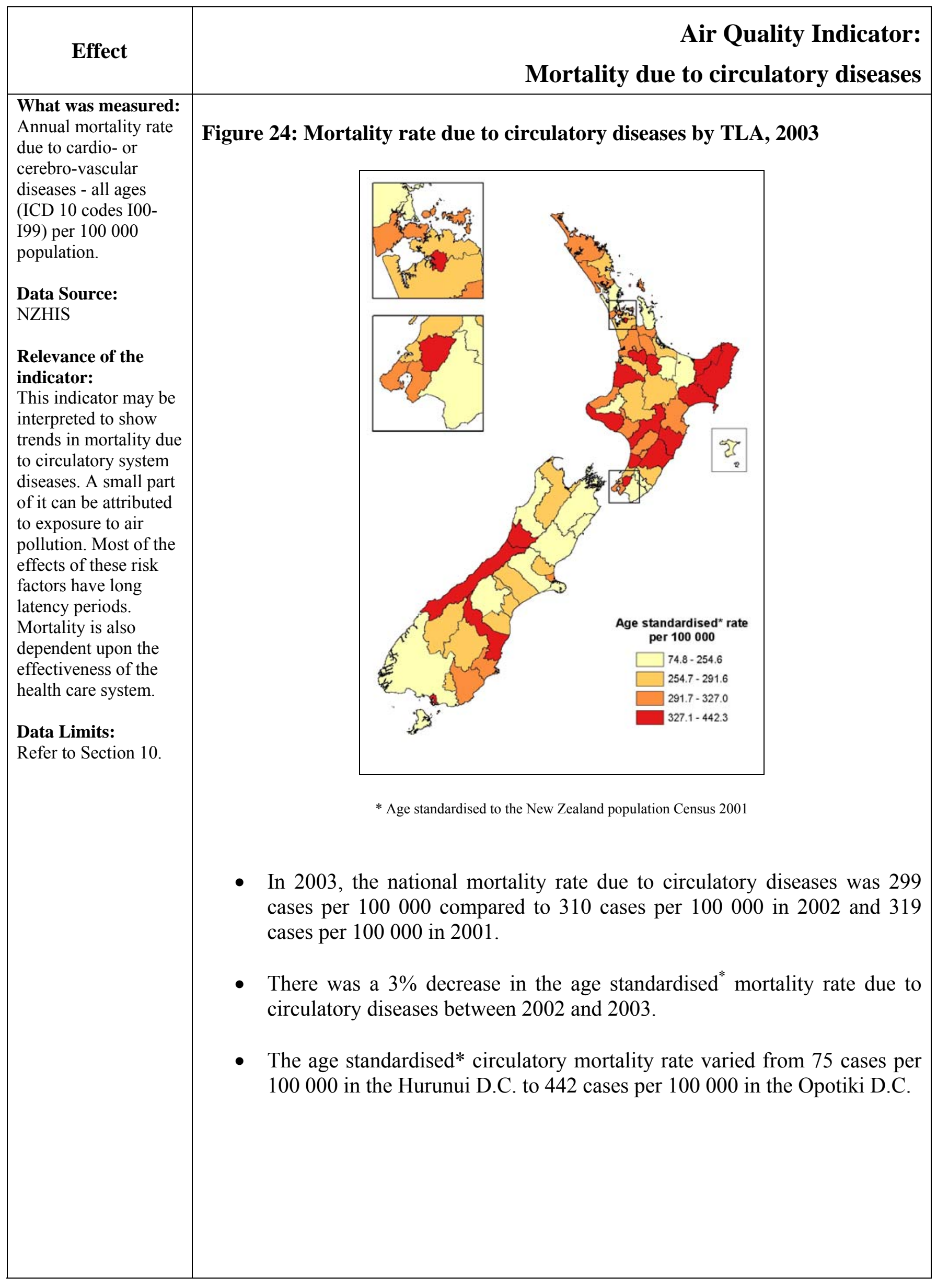




\begin{tabular}{|c|c|}
\hline Effect & $\begin{array}{l}\text { Air Quality Indicator: } \\
\text { Prescription rate for asthma medication }\end{array}$ \\
\hline $\begin{array}{l}\text { What was measured: } \\
\text { Annual prescription } \\
\text { rate for asthma } \\
\text { medication per } 100 \\
000 \text { population. } \\
\text { Data Source: } \\
\text { NZHIS - Pharmhouse } \\
\text { Relevance of the } \\
\text { indicator: } \\
\text { This indicator was } \\
\text { developed as New } \\
\text { Zealand is one of the } \\
\text { few countries which } \\
\text { has a national } \\
\text { prescription database. } \\
\text { It is a standalone } \\
\text { indicator which } \\
\text { illustrates } \\
\text { symptomatic } \\
\text { outcomes. It is the } \\
\text { first step to move } \\
\text { beyond mortality and } \\
\text { morbidity statistics in } \\
\text { order to gain a better } \\
\text { picture of the health } \\
\text { effects when } \\
\text { environmental } \\
\text { exposure is low and } \\
\text { mortality and } \\
\text { morbidity numbers are } \\
\text { low. It assumes that } \\
\text { diagnosed cases have } \\
\text { equal access to } \\
\text { prescription drugs in } \\
\text { differing } \\
\text { socioeconomic parts } \\
\text { of the country. } \\
\text { Data Limits: } \\
\text { Refer to Section } 10 .\end{array}$ & $\begin{array}{l}\text { - } \\
\text { In 2005, the national asthma prescription rate was } 81923 \text { prescription per } \\
100000 \text {. } \\
\text { The asthma prescription rate varied from } 5333 \text { prescriptions per } 100 \text { 000 } \\
\text { in the Chatham Island Territory to } 115991 \text { prescriptions per } 100000 \text { (i.e. } \\
\text { more than one prescription per person) in the Kawerau D.C. }\end{array}$ \\
\hline
\end{tabular}




\subsection{Actions to reduce the burden of disease from poor air quality}

Existing and possible measures include:

\section{Reduce private vehicle dependency}

New Zealand has transport policies that promote the use of public transport and research on passenger land transport, e.g. the Land Transport Act 1998 requires every regional council/unitary authority to prepare a Regional Land Transport Strategy (RLTS). A RTLS must take into account any national land transport strategy and the National Energy Efficiency and Conservation Strategy. The National Energy Efficiency and Conservation Strategy which was released in 2001 and the 2005 strategy titled "Getting there - On Foot, By Cycle" (Ministry of Transport 2005), includes measures aimed at promoting low energy transportation such as cycling, walking and public transport. In addition changes to the passenger transport funding system have seen substantial growth in passenger number since that time. Longer-term developments, such as the planned improvements to the rail system in Auckland, have provided positive trends in this area.

In 2007, the government announced plans to introduce legislation which will enable regional councils to provide better local public transport services. This is likely to reduce private vehicle dependency by providing better value for money (King 2007a). The proposed legislative changes are a key factor in achieving the goal of environmental sustainability.

\section{Vehicle emissions}

Promotion of low or ultra-low sulphur fuels to facilitate the introduction of advanced nitrogen oxide abatement and particulate filters. For example, the Petroleum Products Specifications Regulations 2002 administered by the Ministry of Economic Development have provided for the following reductions in sulphur levels for diesel:

- Effective from $1^{\text {st }}$ September 2002 - 1000 parts per million (ppm) maximum pool average and $1400 \mathrm{ppm}$ maximum cap for Auckland and Northland; $2200 \mathrm{ppm}$ maximum pool average and $3000 \mathrm{ppm}$ maximum cap for the rest of the country.

- Effective from $1^{\text {st }}$ August $2004-500$ ppm maximum pool average and 600 ppm maximum cap.

- Effective from $1^{\text {st }}$ January $2006-50$ ppm maximum. Similar action is being taken around the world. For example, Australia currently requires $500 \mathrm{ppm}$ maximum sulphur in diesel and has moved to $50 \mathrm{ppm}$ as of $1^{\text {st }}$ January 2006. Further reductions in sulphur levels are indicated in the Regulations: diesel sulphur content of 10-15 ppm no later than 2009-10; indicative petrol sulphur content of $50 \mathrm{ppm}$ from 2008; and ultimate requirement for "sulphur free" petrol of 10-15 ppm maximum sulphur content.

In June 2005 the government announced a series of measures to tackle the problem of air pollution from vehicles. These included:

- Prohibiting the removal, or tampering with emission control technology in vehicles.

- Introduction of new fuel specification regulation (2002) to allow up to $10 \%$ ethanol in petrol.

- Investigation into the potential use of congestion pricing for roads in major urban areas.

- Investigation of more sustainable settlement designs and forms (Ministry for the Environment 2005).

- Developing fuel consumption/efficiency labelling for cars entering New Zealand.

- Support integrated land use planning, which reduces traffic demand and generates sustainable travel solutions. 
In October 2006, the government introduced that all vehicles must pass a five-second visible smoke check in order to obtain their warrant or certificate of fitness (Ministry of Transport 2007). The reason for this ruling is that vehicles out of tune or in need of repair produce smoke (blue for petrol vehicles and black for diesel vehicles). Overseas research shows harmful links between this vehicle exhaust smoke and emissions of harmful pollutants, therefore, the reduction of vehicle exhaust smoke is beneficial to health status. This ruling applies to most vehicles with the exception of historic vehicles (where evidence can be provided that the emission of unavoidable smoke is because of original design). Although less effective than metering (which will identify a greater proportion of vehicles as polluters), it is anticipated the smoke check will serve to remove the worst offenders from the road.

2007 has seen a government decision that will require an increasing proportion of cleanerburning biofuels to be sold. The aim is for a reduction in greenhouse gas emissions. The sales obligation, starting in April 2008, would require 3.4\% of the total fuel sold by oil companies to be biofuel by 2012. The biofuels most likely to be sold in New Zealand are biodiesel and bioethanol (Tizard 2007). The decision to promote the sale of biofuels leads on from announcements in December 2006 imposing tougher restrictions on new car imports to ensure they would comply with international vehicle emissions standards (Tizard 2006).

In 2007 the Ministry of Transport, Auckland Regional Council, Auckland Regional Transport Authority and the Broken Car Collection Company ran a pilot scheme designed to encourage the public to trade in their old vehicle (which tend to be less fuel efficient and emit more harmful emissions) and exchange it for a period of subsidised public bus and train tickets (\$400). This pilot scheme ended on the 30 June 2007.

\section{Introduction of National Environmental Air Quality Standards}

The NES's introduced in October 2004 will ensure cleaner air for New Zealanders, with bans on previously allowed activities such as open air tyre burning (in effect since October 2004). Finally, the introduction of new National Air Quality Standards introduced in 2004 for enforcement at the local and regional level will provide local authorities with incentive for air emissions controls, reducing the overall level of air pollution for New Zealanders. As of September 2005, regional councils and unitary authorities are required to notify the public (in their respective air sheds) in the event of an exceedance of the five ambient air quality standards; $\mathrm{CO}, \mathrm{NO}_{2}, \mathrm{O}_{3}, \mathrm{PM}_{10}$ and $\mathrm{SO}_{2}$. In addition to the five ambient air quality standards a range of other standards have been introduced, including (see Section 4):

- Seven standards banning activities that discharge significant quantities of dioxins and other toxics into the air.

- A design standard for new wood burners installed in urban areas.

- A requirement for landfills over one million tonnes of refuse to collect greenhouse gas emissions.

\section{Differential transport taxes and charges}

An example is the German ecological taxation policy where a differential tax system on petrol and other fuels was introduced by the German Government in 1999. This resulted in a decline in number of passenger kilometres travelled by car, petrol consumption and $\mathrm{PM}_{10}$ pollution.

In 2007, the government put forward a proposal to enable the provision of regional fuel taxes. These would contribute to the construction of new roading and public transport infrastructure. Treasury and MoT analysis shows that a 2-3 percent increase in public transport mode share results in a 6-8 percent reduction in congested vehicle kilometres travelled (King 2007b). The promotion of public transport through differential transport taxes will contribute to the government's vision of environmentally sustainable transport which in turn will help to reduce ambient air pollution. 


\section{Actions to improve home heating}

Living in a house that is below $16^{\circ} \mathrm{C}$ (the WHO recommended minimum for a living room) can lead to ill health and long-term health problems. Homes that are well insulated and maintained require less heat to reach comfortable indoor temperatures, and have the added benefits of reduced indoor mould and moisture exposures that can contribute to respiratory disease and premature mortality. Heating sources such as coal and wood contribute to particulate matter pollution. Reducing the use of these fuel types and improving the efficiency of remaining domestic burners will help to reduce ambient air pollution in populated areas, especially during the winter months when meteorological conditions are conducive to air stagnation and inversions. For example, the MfE's Warmer Homes Project; Energy Efficiency and Conservation Authority's (EECA's) EnergyWise Home Grants scheme; Environment Canterbury's (Canterbury Regional Council's) Clean Heat Project, which provides incentives and assistance for householders in Christchurch to install "clean heating". All wood burners installed indoors after $1^{\text {st }}$ September 2005, on a property less than two hectares, must comply with the MfE's National Environment Standards for Air Quality. The National Environment Standards requires wood burners to meet an emission limit of less than $1.5 \mathrm{~g} / \mathrm{kg}$ (grams of particulate per kilogram of wood burnt) and an efficiency of greater than $65 \%$.

In conjunction with Australia, New Zealand has developed its own set of standards, which are related to wood burner performance. All appliances sold in New Zealand must comply with these requirements.

Finally, the interest-free loan scheme was announced as part of the Budget 2007. The intention of the interest-free loan scheme is to help low to middle income home-owners install or upgrade to energy efficient products (such as insulation, efficient lighting, and hot water cylinder wraps) and clean heating devices in their homes. This funding will be available to cover the interest component of loans provided by third parties to qualifying household. Initial estimates suggest that the funding available will be sufficient to cover the interest and administrative costs associated with around 5000 energy efficiency and 1500 clean heating retrofits per annum. 


\section{ROAD TRANSPORT}

Figure 26: DPSEEA Framework: Road Transport Indicators

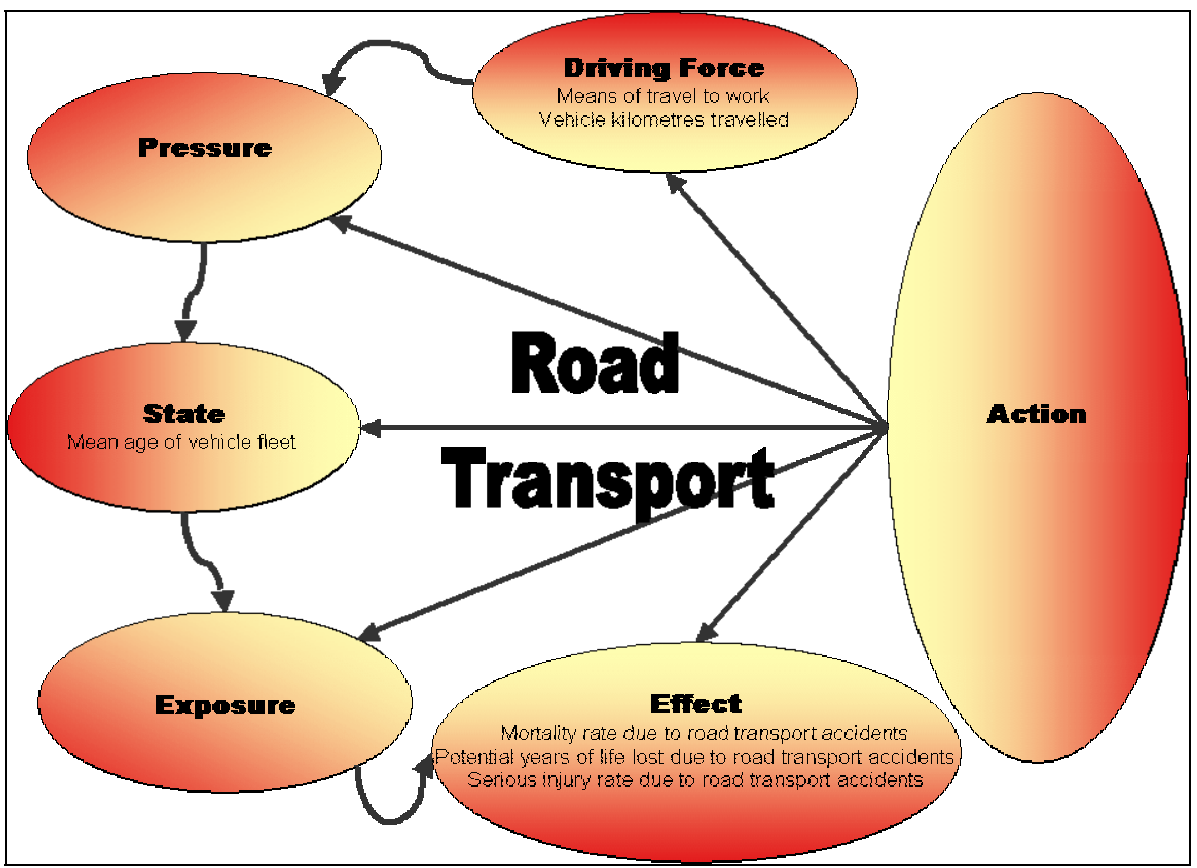

Population growth is a significant driving force for all environmental health issues and plays an important role in relation to the pressures on the environment and consequent impact on health. An increase in population also results in a greater demand for goods and services with increased commercial activity and waste products.

In the last 50 years, the national population has doubled however the number of motor vehicles has increased six fold (Land Transport Safety Authority cited in Kjellstrom \& Hill 2002). New Zealand has one of the highest rates of motor vehicle ownership in the world with an average of 69 vehicles per 100 people (Ministry for the Environment 1997).

\subsection{Driving forces influencing road transport}

- Means of travel to work (Figure 27).

- Vehicle kilometres travelled (Figure 28).

Transport used for commuting to work is a good indicator to understand how public and private transports are used (Figure 27). In addition the number of kilometres driven by vehicles is a significant driving force for traffic accidents (Figure 28).

\subsection{State of road transport}

- Mean age of vehicle fleet (Figure 29).

The age of a vehicle passenger fleet measures the years of usage for each car and the quality of the car fleet, which, in turn, affects the severity of injuries occurring to occupants of passenger cars (Figure 29). Changes in injury severity can be due to improvement in fleet composition (replacing older vehicles with newer ones), driver safety and environmental conditions. For example, vehicles constructed before 1984 had a significantly greater chance of being involved in an injury crash than those constructed after 1984. One study found that the increase was threefold (odds ratio 2.88 , 95\% CI 1.20 to 6.91), after adjusting for potential confounders. Though not statistically significant there was also an indication of a trend of increasing crash 
risk with each one-year increase in vehicle age after adjustment for potential confounders (odds ratio $1.05,95 \%$ CI 0.99 to $1.11 ; p=0.09$ ) (Blows, Ivers et al. 2003).

Other factors such as the vehicle model, weight, mileage, maintenance record, engine load, temperature and fuel type also contribute to total emissions (Wenzel, Singer et al. 2000).

\subsection{Health effects associated with road transport}

- Serious injury rate due to road transport accidents (Figure 30).

- Mortality rate due to road transport accidents (Figure 31).

- Potential years of life lost due to road transport accidents (Figure 32).

Injuries caused by road traffic accidents are a global public health problem (Figure 30 to 32 ). They are the leading cause of death by injury and the ninth leading cause of all deaths worldwide. In 2000, about 12600000 persons were killed in road crashes with an additional 10-15 million people injured every year. Road traffic accidents are the most important cause of death among young people, especially males and are a major cause of physical disability, especially among the young. Over $50 \%$ of the global mortality due to road traffic injury occurs among young adults aged 15-44 years (World Health Organization 2004c). 
What was measured: Main means of travel to work, for the employed census usually resident population, aged 15 years and over.

\section{Data Source:}

Statistics New

Zealand, 2006 Census.

Relevance of the indicator:

The journey to work is a particularly important and regular journey undertaken by a large proportion of the population. As such it may be more effectively targeted by a wide range of policies aimed at reducing the dependence on travel in private motor vehicles. The means of travel to work will provide a measure of how successful such policies are.

Data limits:

Refer to Section 10.
Figure 27: Means of travel to work by TLA, 2006

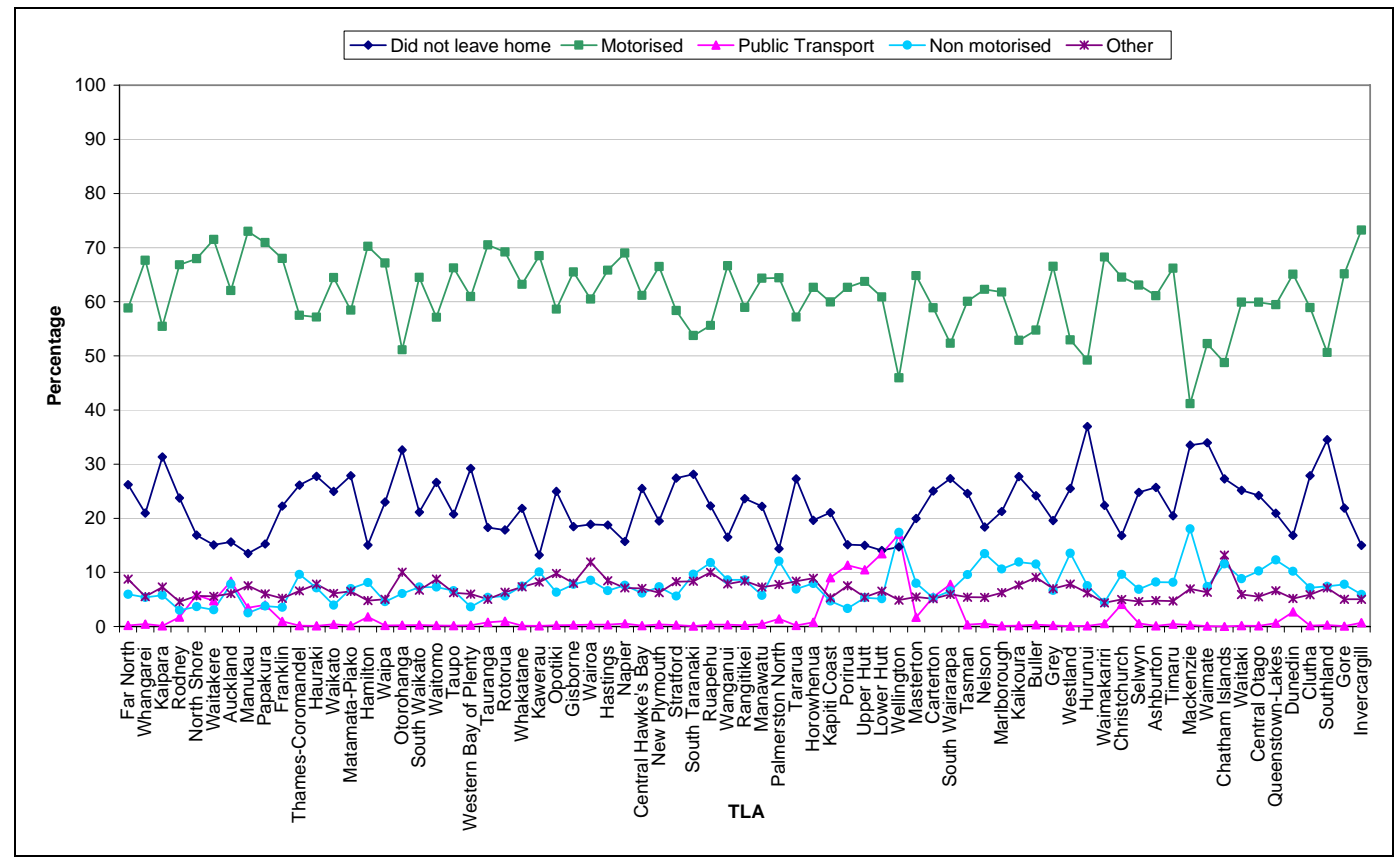

- In 2006, nationally, $79 \%$ of the population drove or were a passenger in a car, truck or van or motorcycle on their way to work.

- Overall, the most common means of travel to work was motorised, followed by did not leave home, non-motorised and other, and then public transport.

- Among people who used some form of transport to go to work, the highest proportion of people using motorised transport was in the Waimakariri D.C. $(87.9 \%)$ followed by the Rodney D.C. $(87.7 \%)$.

- Among people who used some form of transport to go to work, the highest proportion of people using non-motorised transport was in the Mackenzie D.C. $(27.2 \%)$ followed by the Wellington C.C. $(20.4 \%)$.

- Among people who used some form of transport to go to work, the highest proportion of people using public transport were in the Wellington C.C. $(20.0 \%)$ followed by the Lower Hutt C.C. (15.6\%). 
What was measured: Annual number of vehicle kilometres travelled divided by TLA land area, and multiplied by the TLA population for 2002 .

\section{Data Source:}

Ministry of Transport.

\section{Relevance of the} indicator:

This indicator is based on the assumption that the number of transport vehicles and the number of kilometres driven by them represent a significant driving force for traffic accidents. This indicator measures the amount of exposure to road travelling, it takes into account only powered users. The distances travelled can be very different depending on the urbanisation, geographical conformation and development of the road network.

Data limits:

Refer to Section 10.

Linkages with other indicators:

This indicator is a driving force indicator for both air quality and road transport.
Figure 28: Vehicle kilometres travelled by TLA, 2002

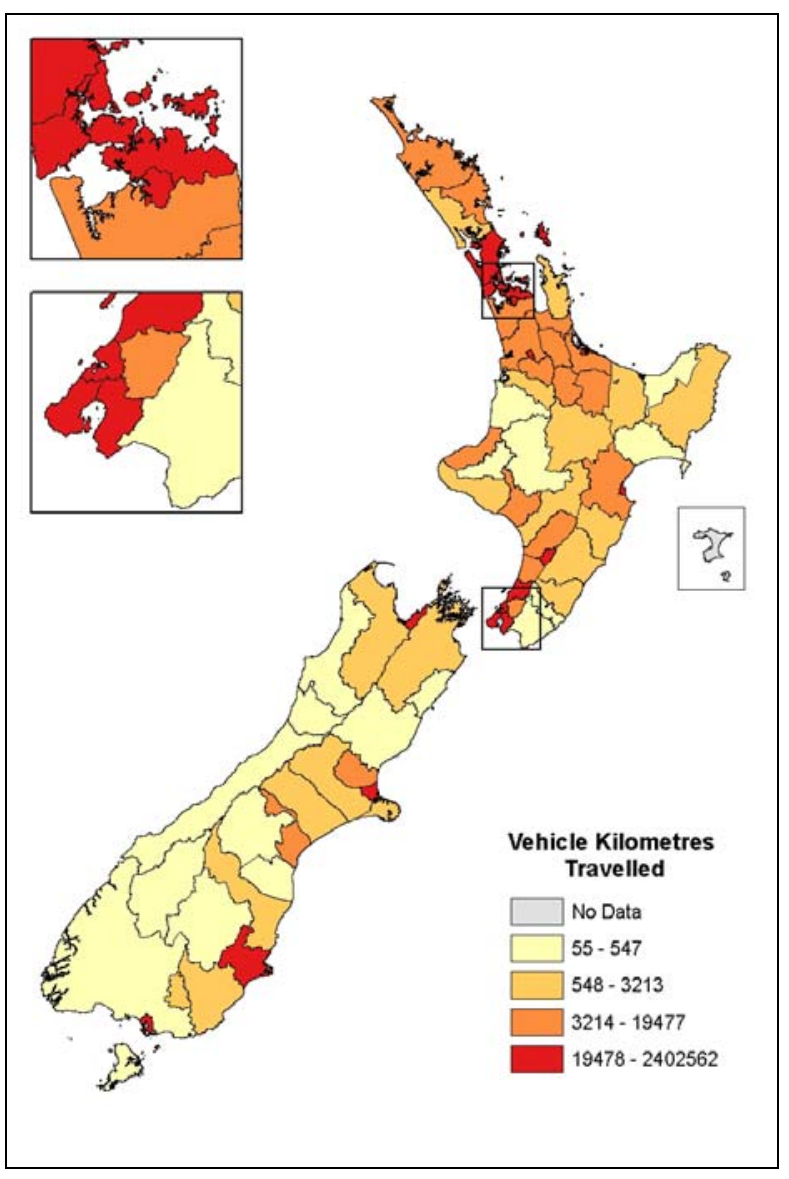

- In 2002, the TLA with the highest number of vehicle kilometres travelled was the Auckland C.C. (2 402 562) followed by the North Shore C.C. (1 886470$)$.

- In 2002, the TLA with the lowest number of vehicle kilometres travelled was the Mackenzie D.C. (55) followed by the Westland D.C. (117). 


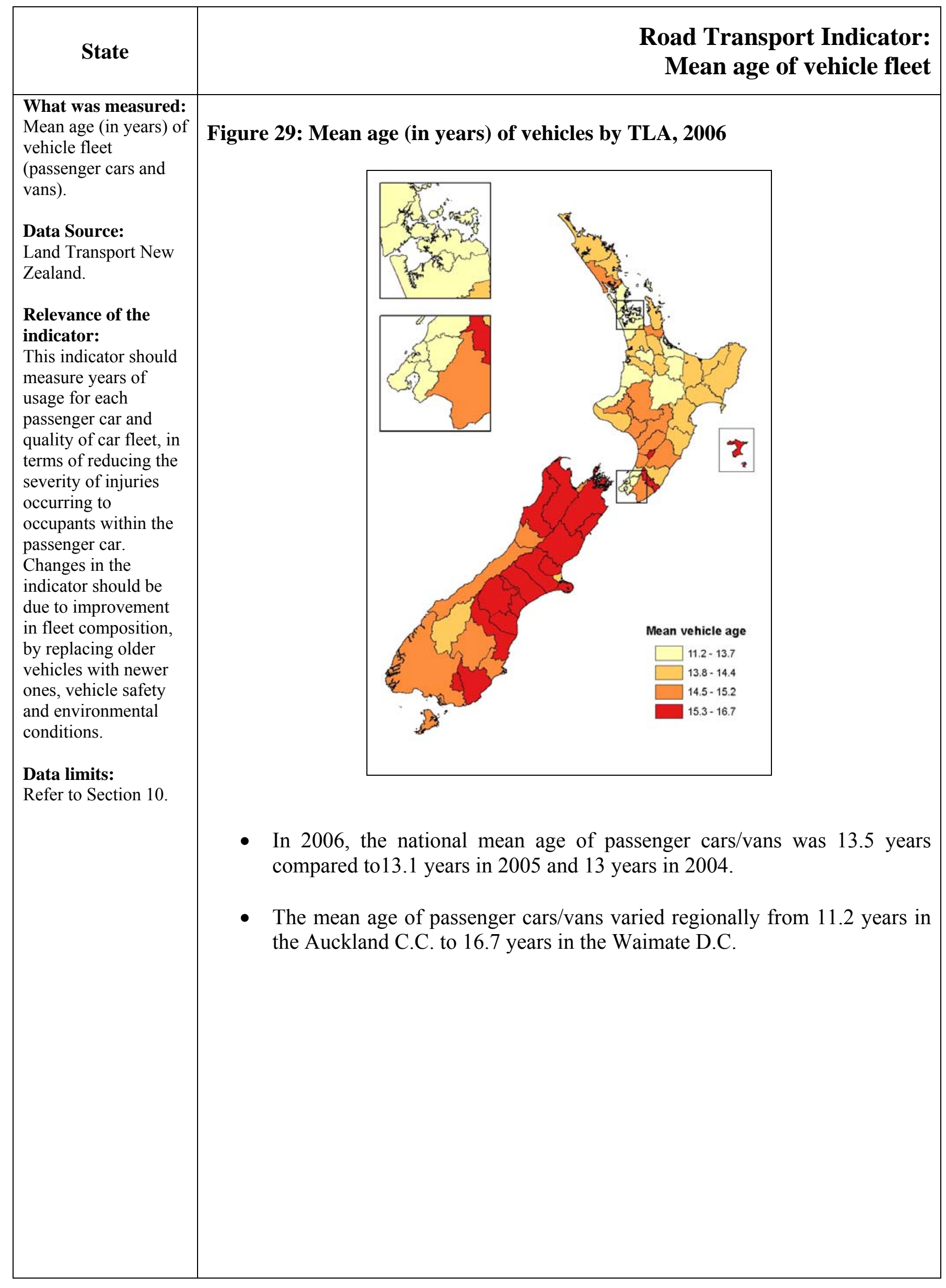




\section{Serious injury rate due to road transport accidents}

What was measured: Annual serious injury rate due to road traffic accidents per 100000 people.

\section{Data Source:}

Ministry of Transport.

Relevance of the indicator:

This indicator is general relatively easy to interpret in that the link between the cause and health effect is explicit. Changes in the indicator should be due to reduction in total traffic volume, greater segregation of pedestrian from road traffic, improvement in: road design, traffic management, vehicle safety, environmental conditions as well as health promotion safety campaigns.

\section{Data limits:}

Refer to Section 10.
Figure 30: Serious injury rate due to road transport accidents by TLA, 2006

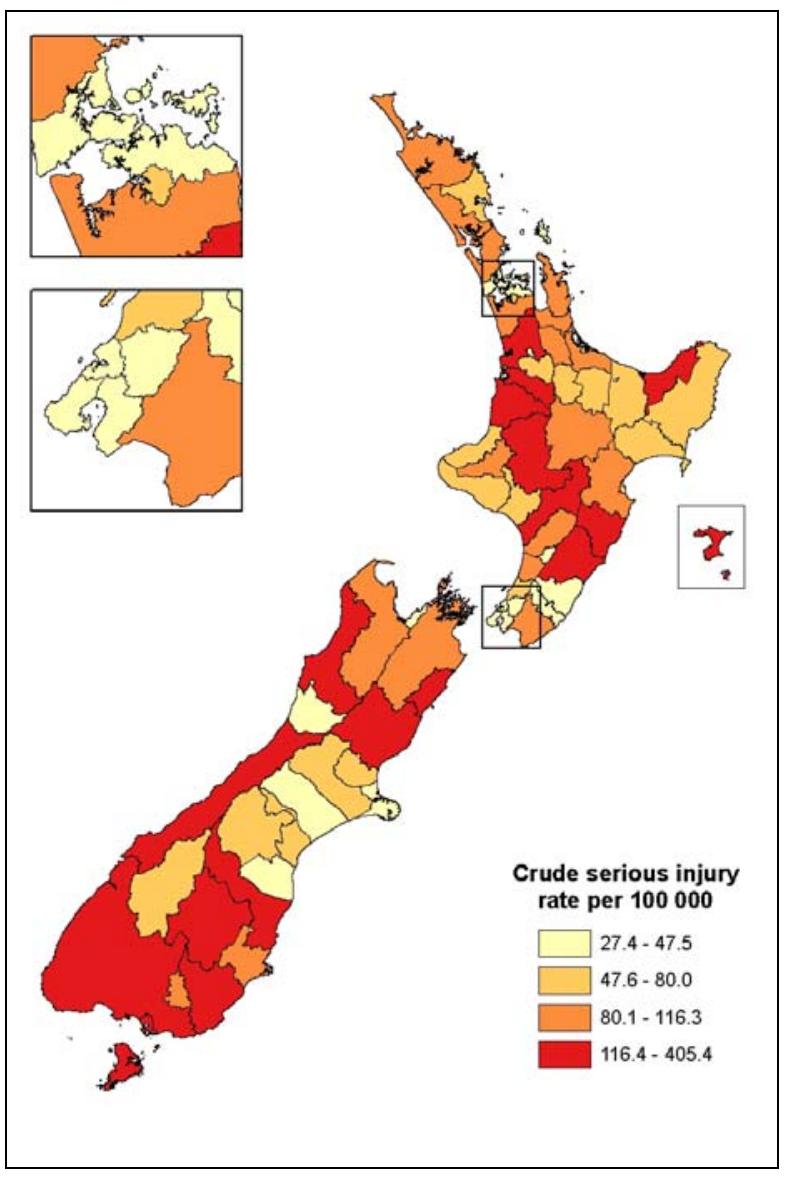

- In 2006, the national serious injury rate due to road transport accidents was 64 cases per 100000 compared to 62 cases per 100000 in 2005 and 61 cases per 100000 in 2004.

- The highest serious injury rate was observed in the Chatham Islands D.C. (405 cases per 100000 ) followed by the Westland D.C. (268 cases per 100 000).

- The lowest serious injury rate was observed in the North Shore C.C. (27 cases per 100000$)$ followed by the Hamilton C.C. (28 cases per 100000$)$.

- The three leading contributing factors for serious injury accidents were lost control (13\%), alcohol (12\%) and going too fast for conditions (11\%).

- In 2006, of all serious road transport accidents, $6 \%$ involved cyclists, $10 \%$ involved pedestrians, $15 \%$ involved motorcyclists, $23 \%$ involved passengers and $46 \%$ involved drivers. 


\begin{tabular}{|c|c|}
\hline Effect & $\begin{array}{r}\text { Road Transport Indicator: } \\
\text { Mortality rate due to road transport accidents }\end{array}$ \\
\hline $\begin{array}{l}\text { What was measured: } \\
\text { Annual mortality rate } \\
\text { due to road transport } \\
\text { accidents per } 100000 \\
\text { people. } \\
\text { Data Source: } \\
\text { Ministry of Transport } \\
\text { Relevance of the } \\
\text { indicator: } \\
\text { This indicator is } \\
\text { general relatively easy } \\
\text { to interpret in that the } \\
\text { link between the cause } \\
\text { and health effect is } \\
\text { explicit. Changes in } \\
\text { the indicator should be } \\
\text { due to reduction in } \\
\text { total traffic volume, } \\
\text { greater segregation of } \\
\text { pedestrian from road } \\
\text { traffic, improvement } \\
\text { in: road design, traffic } \\
\text { management, vehicle } \\
\text { safety, environmental } \\
\text { conditions as well as } \\
\text { health promotion } \\
\text { safety campaigns. } \\
\text { Data limits: } \\
\text { Refer to Section } 10 .\end{array}$ & 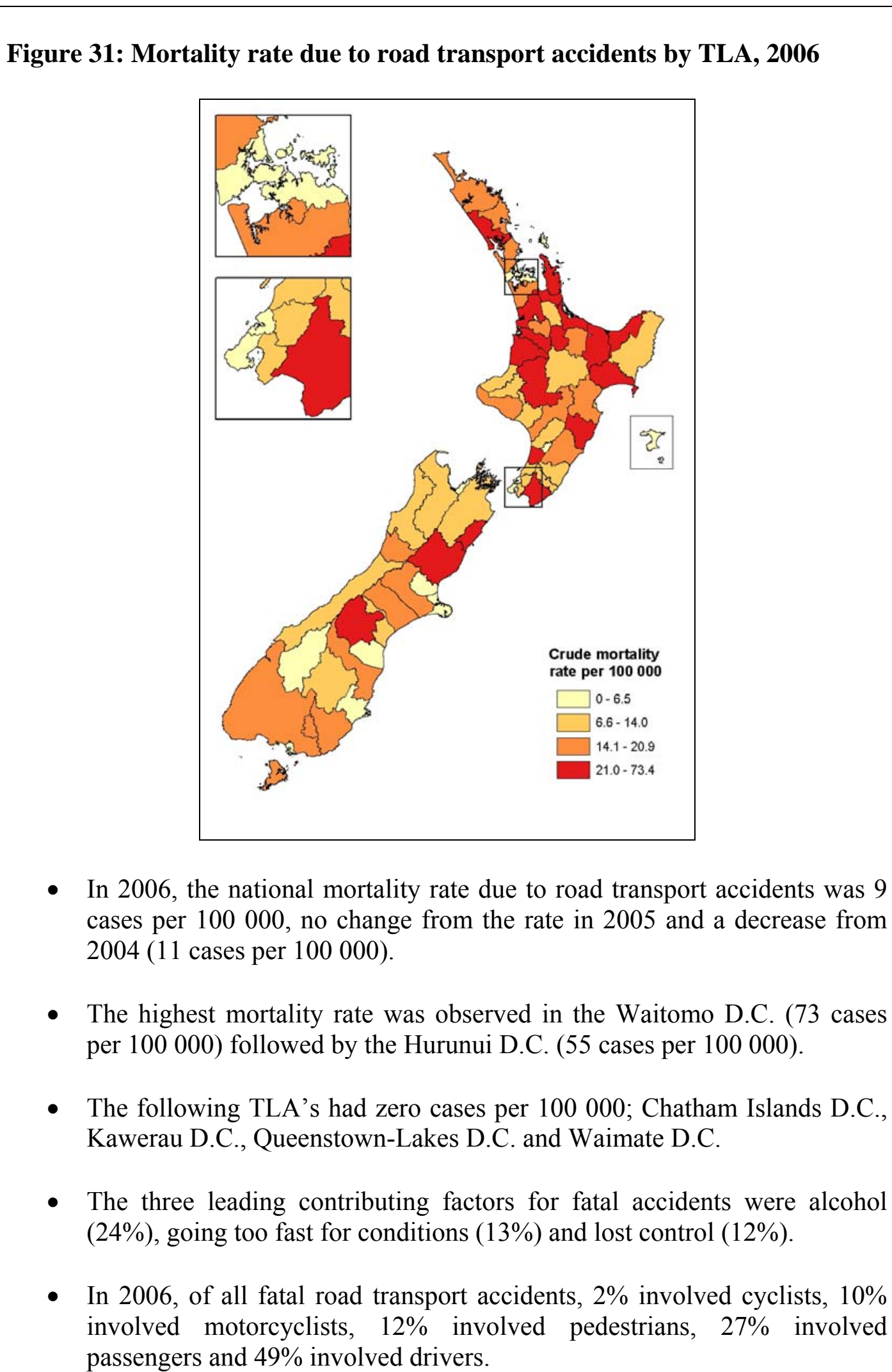 \\
\hline
\end{tabular}




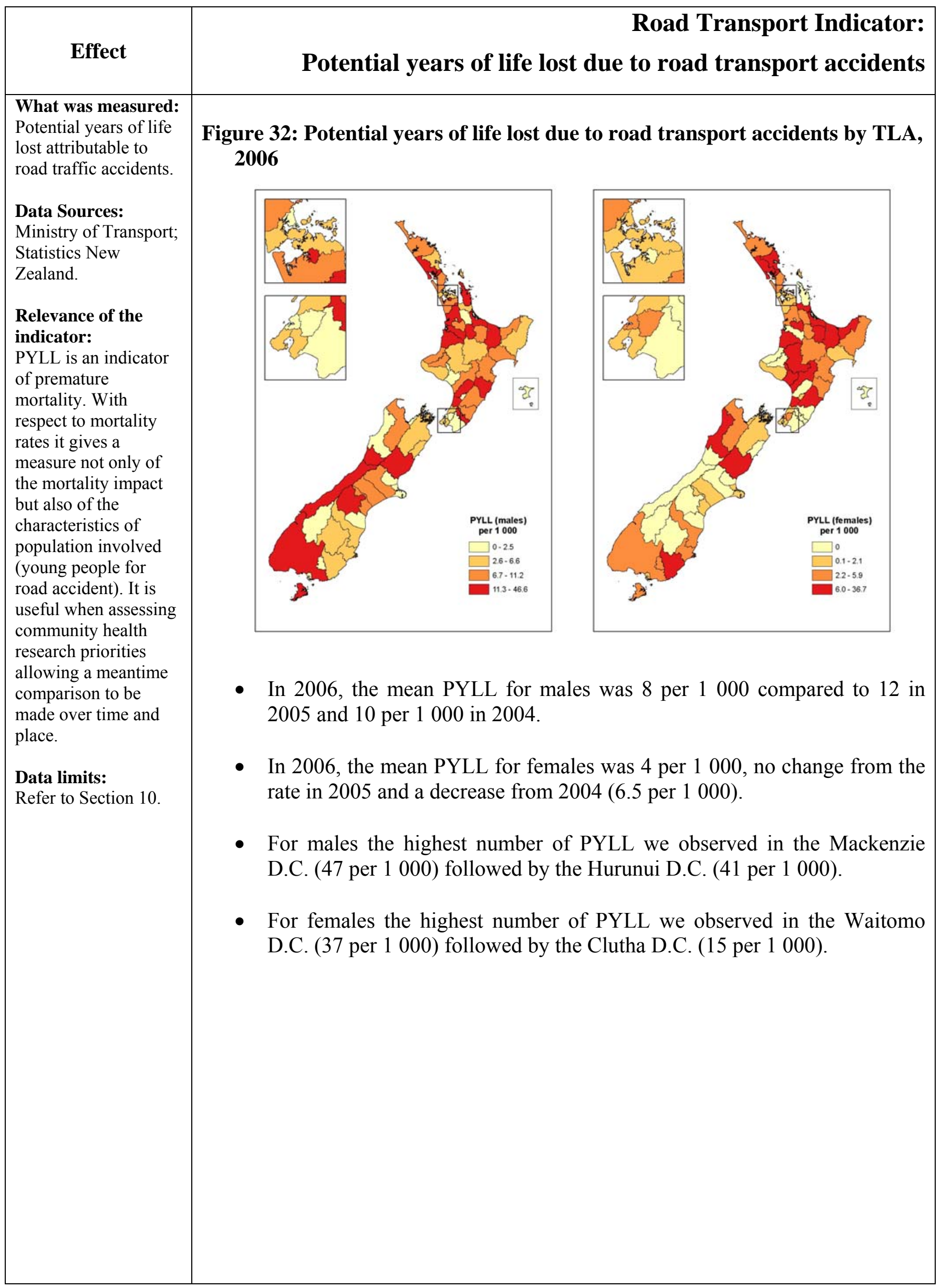




\subsection{Actions to reduce the burden of injury from road transport}

There is sufficient evidence for effective interventions to reduce traffic accidents. A recent review (Morrison, Petticrew et al. 2003) describes the following actions as effective in reducing traffic accidents:

- Health promotion campaigns for the prevention of childhood injury

- Efforts to increase helmet use by cyclists and motorcyclists

- Promotion of the use of children's car seat and seat belts

- Traffic calming

- Specific legislation against drink driving

Jeanne Breen Consulting (2004) in the 'Review of the road safety to 2010 strategy' report state that since 1990, despite traffic growth, road deaths have fallen by 39\%; road death rates have nearly halved per 100,000 population and hospitalisations have fallen by around $33 \%$. This has occurred as a result of the combination of enforcement, engineering (both highway and vehicle) and education interventions comprising measures which include:

- Low cost engineering at 2000 high risk sites resulted in a $50 \%$ reduction in fatal crashes at those sites; skid resistance programmes have led to an average $29 \%$ reduction in wetskid crashes at treated sites since 1995 and median barrier programmes on high volume motorways.

- Improvement in the safety of imported vehicles. For example, between 1997 and 2002, a series of new vehicle safety standards for active and passive safety, e.g. Frontal Impact Rule requiring accelerated take up of a full-width barrier test; requirements related to safety belt, airbags, tyres, wheels, brake and vehicle inspections were put into place. In addition, used car imports can be no more than 7 years old hence lowering the average age of the New Zealand car fleet.

- More than a 50\% reduction in levels of alcohol-related deaths as a result of compulsory breath testing supported by targeted advertising between 1990 and 2002.

- An increase in rear seat belt usage levels from 58\% between $1996-8$ to $80 \%$ in 2002 , again as a result of police enforcement and supporting publicity.

In 2004, the MoH signed up to the World Health Assembly Resolution EB 113.R3 on road safety and health which urged Ministries of Health to be involved in the framing of policy on the prevention of road traffic injuries (Jeanne Breen Consulting 2004). As a result the $\mathrm{MoH}$ is now represented on the National Road Safety Committee. In addition the $\mathrm{MoH}$ has working relationships at officials level with other key partners in injury prevention in general including road and other transport safety. In the area of road safety, the Ministry in partnership with Accident Compensation Corporation, the Land Transport Safety Authority and a range of other government agencies, funds and supports a number of community organisations to implement a range of road safety projects as part of implementing the Road Safety to 2010 strategy (Land Transport Safety Authority 2003). These include:

- Pedestrian and cyclist best practice standards and guidelines

- Safer cycling/pedestrian routes

- Promoting use of cycle safety helmets ("Safekids work")

- Supporting community road safety programmes (through a range of community injury prevention programmes such as "Safe Waitakere")

- Road safety in schools through "Roadsense - Ata Haere"

- Promoting Child Car Seat Restraint use - "Safe To Go" programme

- Health sector forum on road safety and health

- Development of ATV (all terrain vehicle) Helmet standard. 
New Zealand has specific legislation against drink driving namely the Land Transport Amendment Act 2005. It merges a number of pieces of existing land transport legislation including legislation around drink driving. The provisions of the Land Transport Amendment Act 2005 are centred on targeting serious and repeat drink-driving offenders.

On $24^{\text {th }}$ February 2005, the Government launched Getting there - on foot, by cycle: A strategy to advance walking and cycling in New Zealand transport (Ministry of Transport 2005).

In 2007 the Ministry of Transport, Auckland Regional Council, Auckland Regional Transport Authority and the Broken Car Collection Company ran a pilot scheme designed to encourage the public to trade in their old vehicle (which tend to be less fuel efficient and emit more harmful emissions) and exchange it for a period of subsidised public bus and train tickets (\$400). This pilot scheme ended on 30 June 2007. 


\section{BIOSECURITY}

Figure 33: DPSEEA Framework: Biosecurity Indicators

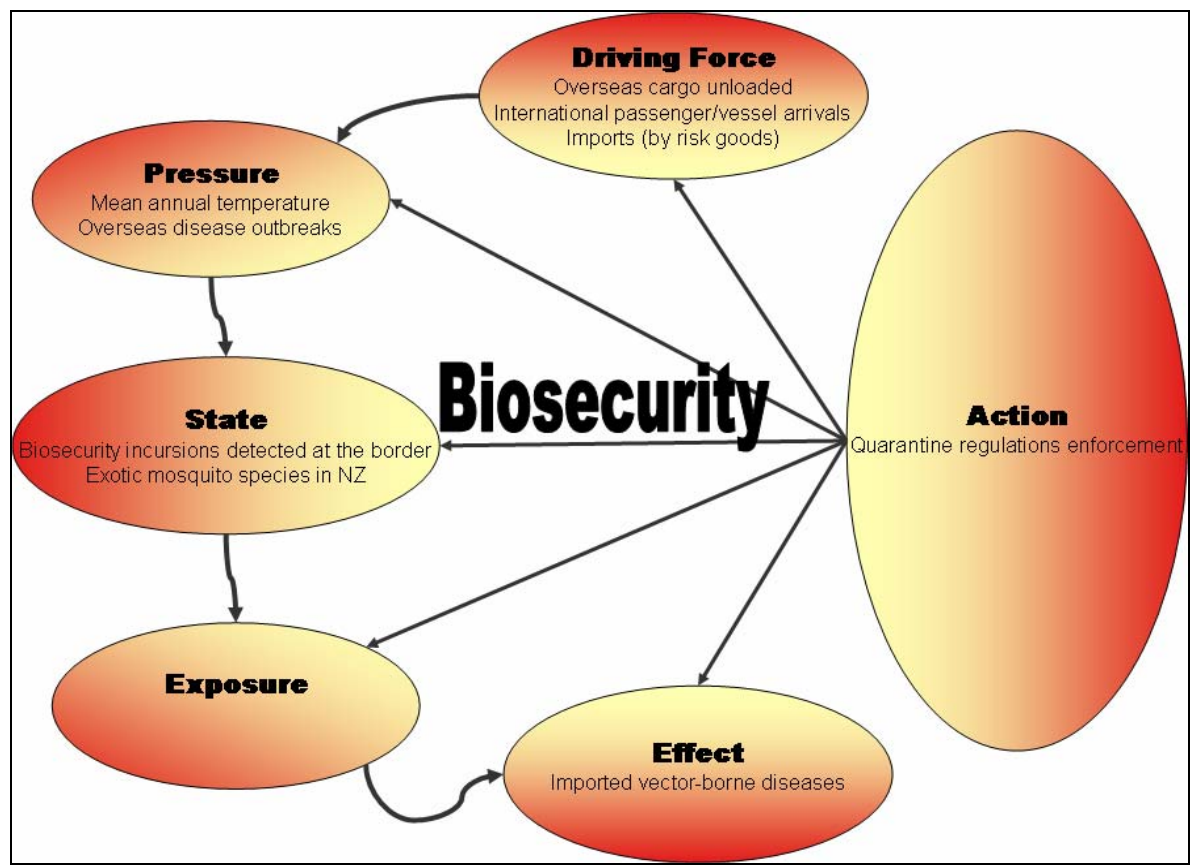

This is the second year Biosecurity Indicators have been included in the Environmental Health Indicators for New Zealand annual report.

Biosecurity can be described as the exclusion, eradication and effective management of risks posed by pests and diseases to the economy, environment and human health (Biosecurity Council 2003). Possible biosecurity threats to New Zealand include pests and diseases such as foot and mouth disease, rabies, scrapie, arboviruses, and other zoonotic diseases. Acts of bioterrorism in New Zealand are considered unlikely in the current environment, but may change with ongoing global trends of increasing externally perpetrated and homegrown terrorism.

Internationally, we are experiencing the emergence, re-emergence, and spread of infectious diseases (Wilcox \& Colwell 2005; Wilcox \& Gubler 2005). Some examples include West Nile virus, Severe Acute Respiratory Syndrome (SARS), avian influenza, and dengue fever. It is possible that New Zealand could experience an outbreak of one of these disabling or life threatening diseases in the future.

The mechanisms and processes involved in the emergence and spread of infectious diseases are complex. However, human activities are frequently being identified as the primary cause for their emergence and spread (e.g. see Aron \& Patz 2001). Using the DPSEEA framework (Figure 33) illustrates indicators that can be used to understand the possible causal pathway to the importation and local acquisition of human diseases from a biosecurity perspective.

\subsection{Driving forces influencing biosecurity}

- Overseas cargo unloaded (Figure 34).

- International vessel arrivals (Figure 35).

- International passenger arrivals (Figure 36).

- Imports (by risk goods) (Figure 37). 
Economic development, consumerism, globalisation and population growth, are examples of key driving forces responsible for the emergence and spread of infectious diseases. Increased global demand for products and raw materials coupled with increased international travel has led to the expansion of sea and air trade routes and passenger traffic (Figures 34 to 37). This has resulted in the spread of exotic organisms, pathogens and associated diseases (e.g. Aedes albopictus, SARS and malaria), particularly via the transport of risk goods (e.g. used machinery and cars, tyres) (Frampton 2005, Lounibos 2002, Tatem, Hay et al. 2006; Tatem, Rogers et al. 2006).

\subsection{Pressures influencing biosecurity \\ - Overseas disease outbreaks (Figure 38). \\ - Mean annual temperature (Figure 39).}

The spread of exotic organisms and pathogens can be further exacerbated by pressures, such as the movement of people from disease outbreak areas and climate change (Figures $38 \& 39$ ). The possible direct and indirect effects of climate change on human health are numerous (Aron \& Patz 2001; Woodward, Hales et al. 2001). With respect to biosecurity, increased temperatures may facilitate the establishment and/or spread of some exotic organisms, which may pose a health risk (de Wet, Slaney et al. 2005; Rogers \& Randolph 2006).

\subsection{State of biosecurity \\ - Exotic mosquito species in New Zealand (Figure 40). \\ - Health related biosecurity incursions}

See Section 8.4 for explanation of indicator.

\subsection{Health effects associated with biosecurity \\ - Imported vector-borne diseases (Figure 41).}

The biosecurity impacts of these driving forces and pressures can be measured using the state and effect indicators, e.g. the current known distribution of exotic mosquito species in New Zealand, the number of human health related biosecurity incursions detected at the border and the number of imported vector-borne disease cases (Figures 40 \& 41). For an exposure indicator, the percentage of the population at risk from the entry of these organisms or pathogens into New Zealand could be developed, e.g. this could be the percentage of the population living in close proximity to ports.

\subsection{Actions to improve biosecurity \\ - Quarantine regulations enforcement (Figure 42).}

In response to the above biosecurity concerns, various actions can be implemented at different points within the DPSEEA framework. For example, the development of the Biosecurity Strategy, which aims to provide a direction for New Zealand's biosecurity at the pre-border, border and post-border to keep out exotic organisms and diseases (Biosecurity Council 2003). Other government actions designed to reduce the risk of exotic organism and disease introduction, include infringement fines at international ports of entry for false biosecurity declarations (Figure 42). Infringement fines were introduced by the MAF in mid-2001. The \$200 fines are designed to help enforce compliance with New Zealand's biosecurity laws and change human behaviour to be more responsive to keeping New Zealand free of exotic organisms and diseases. 


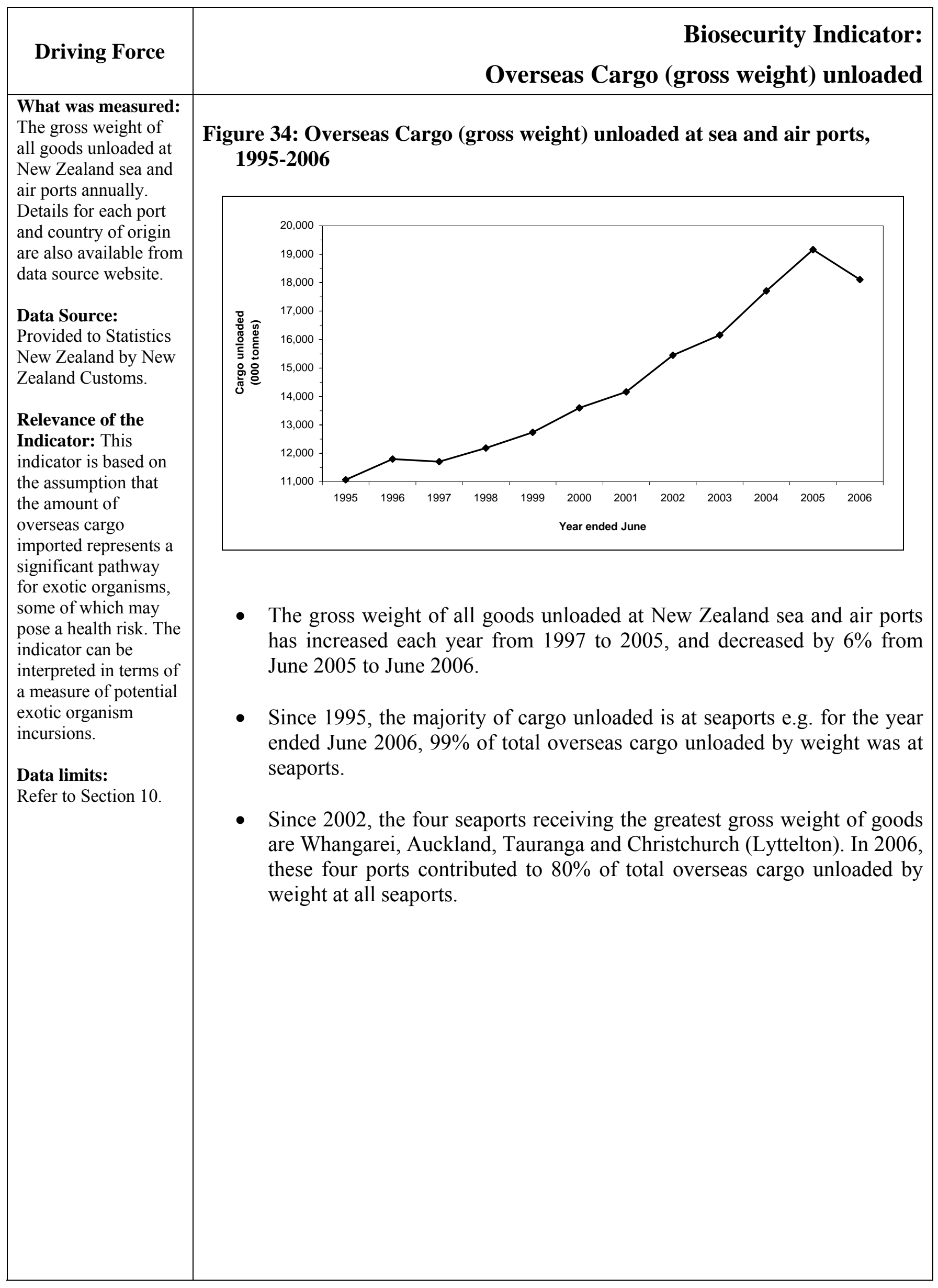




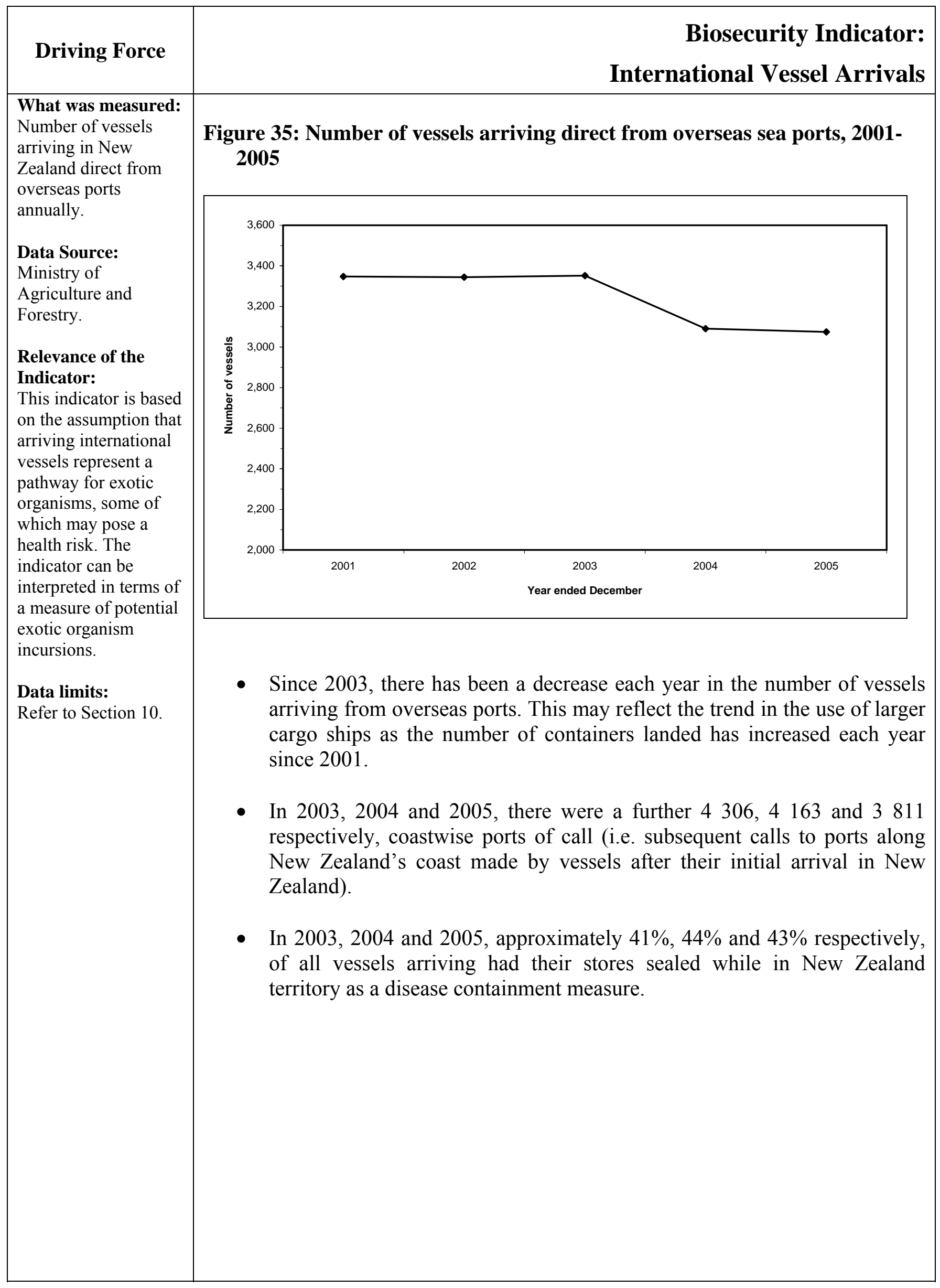




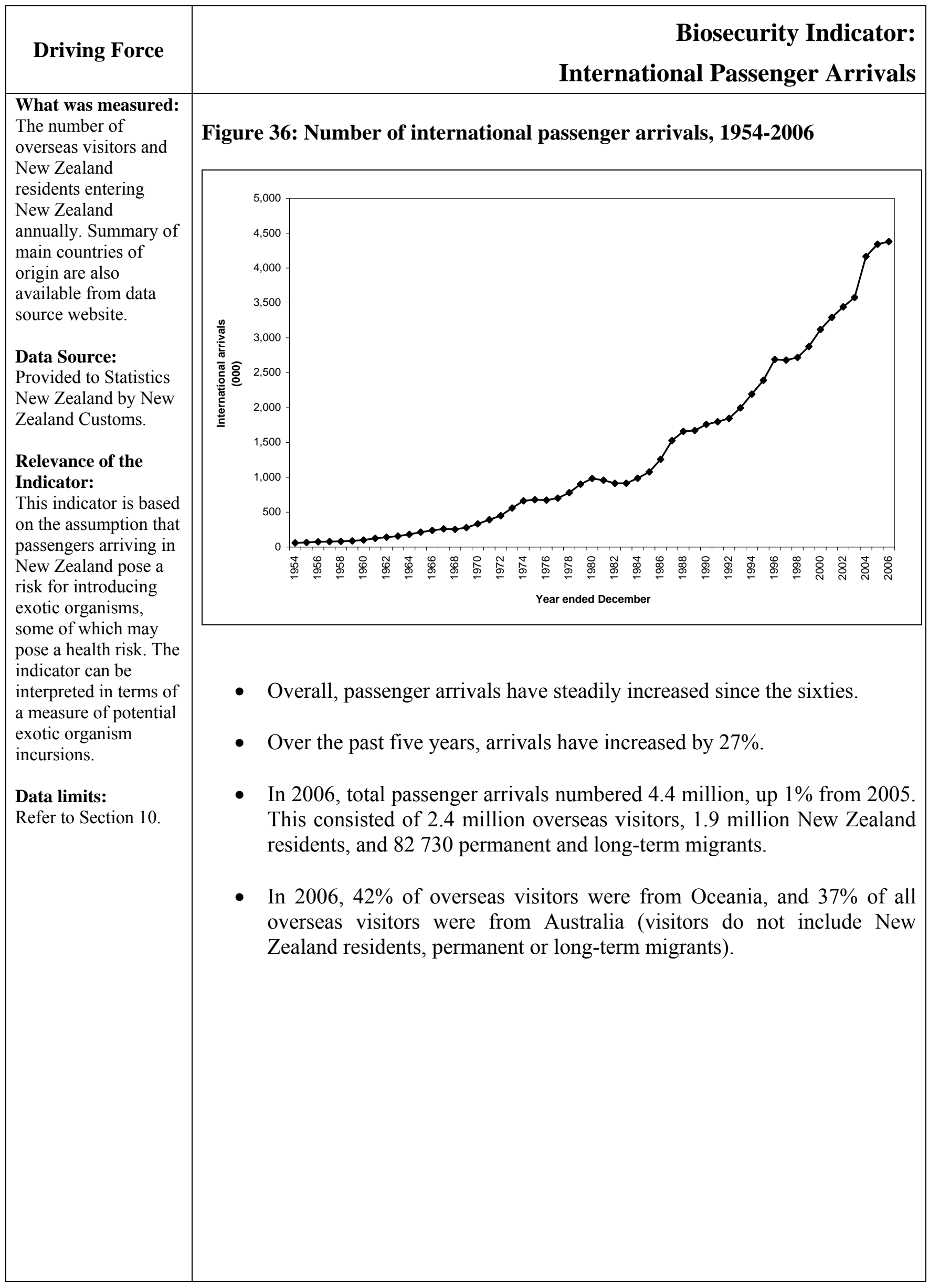




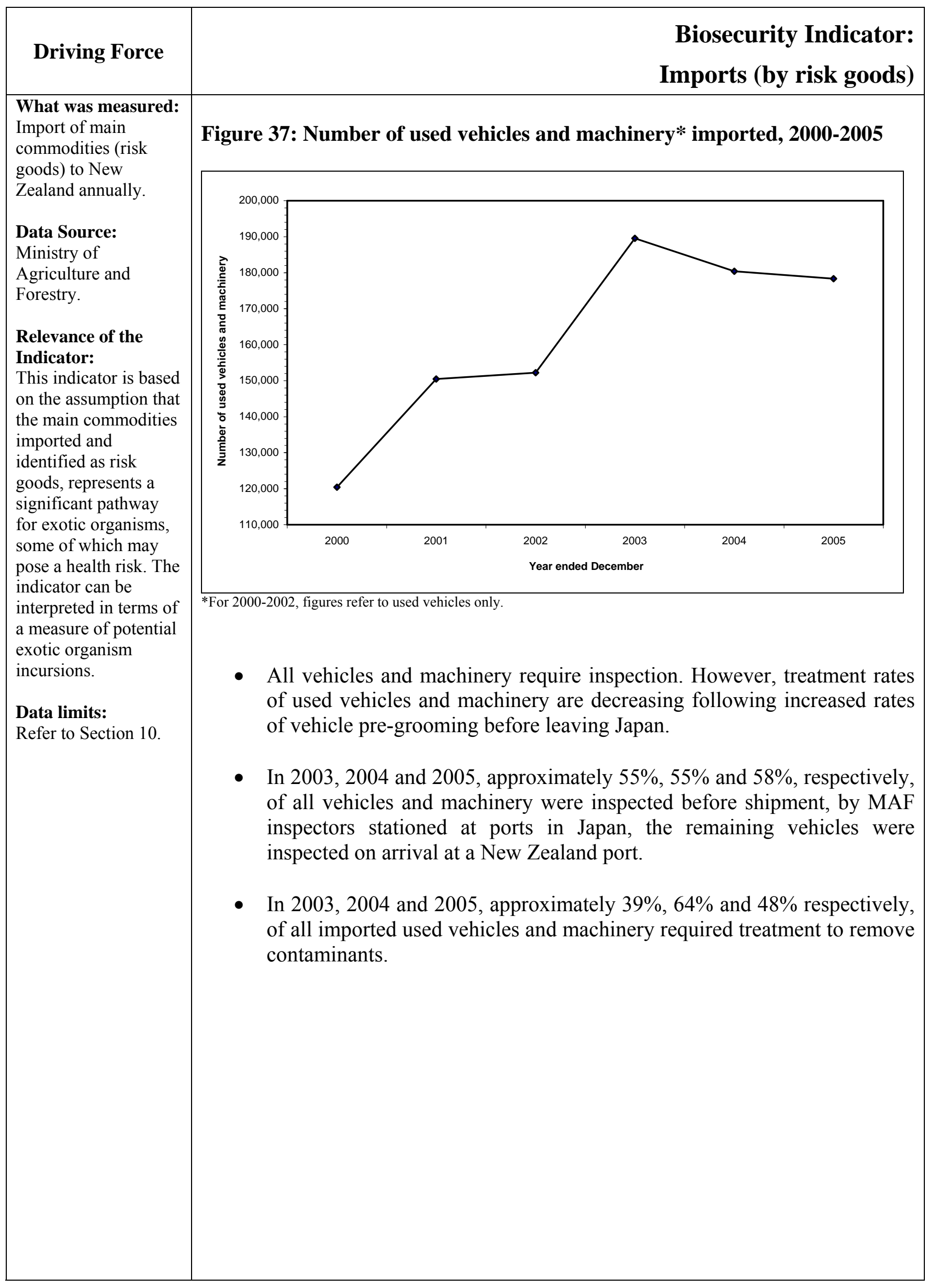




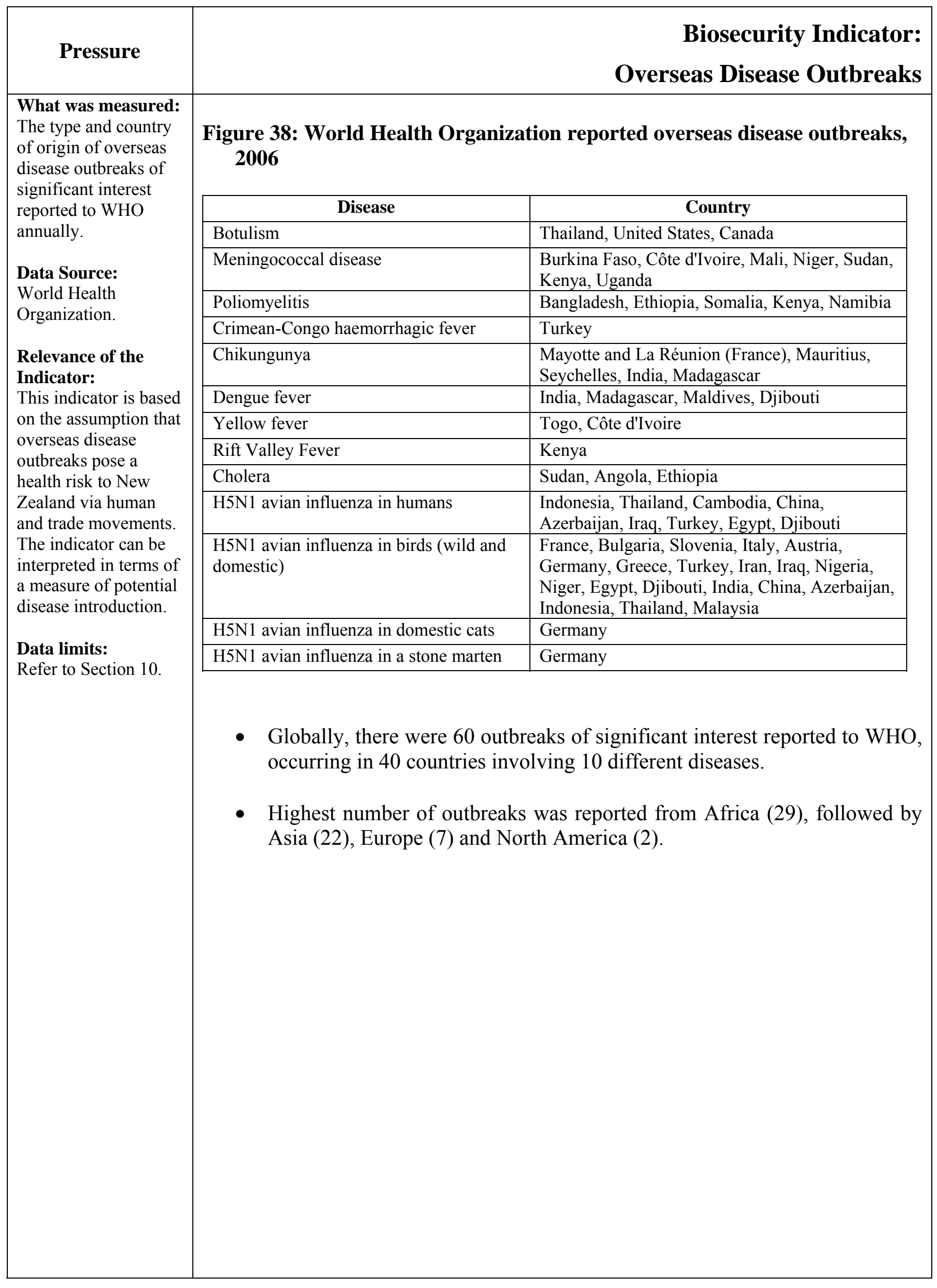




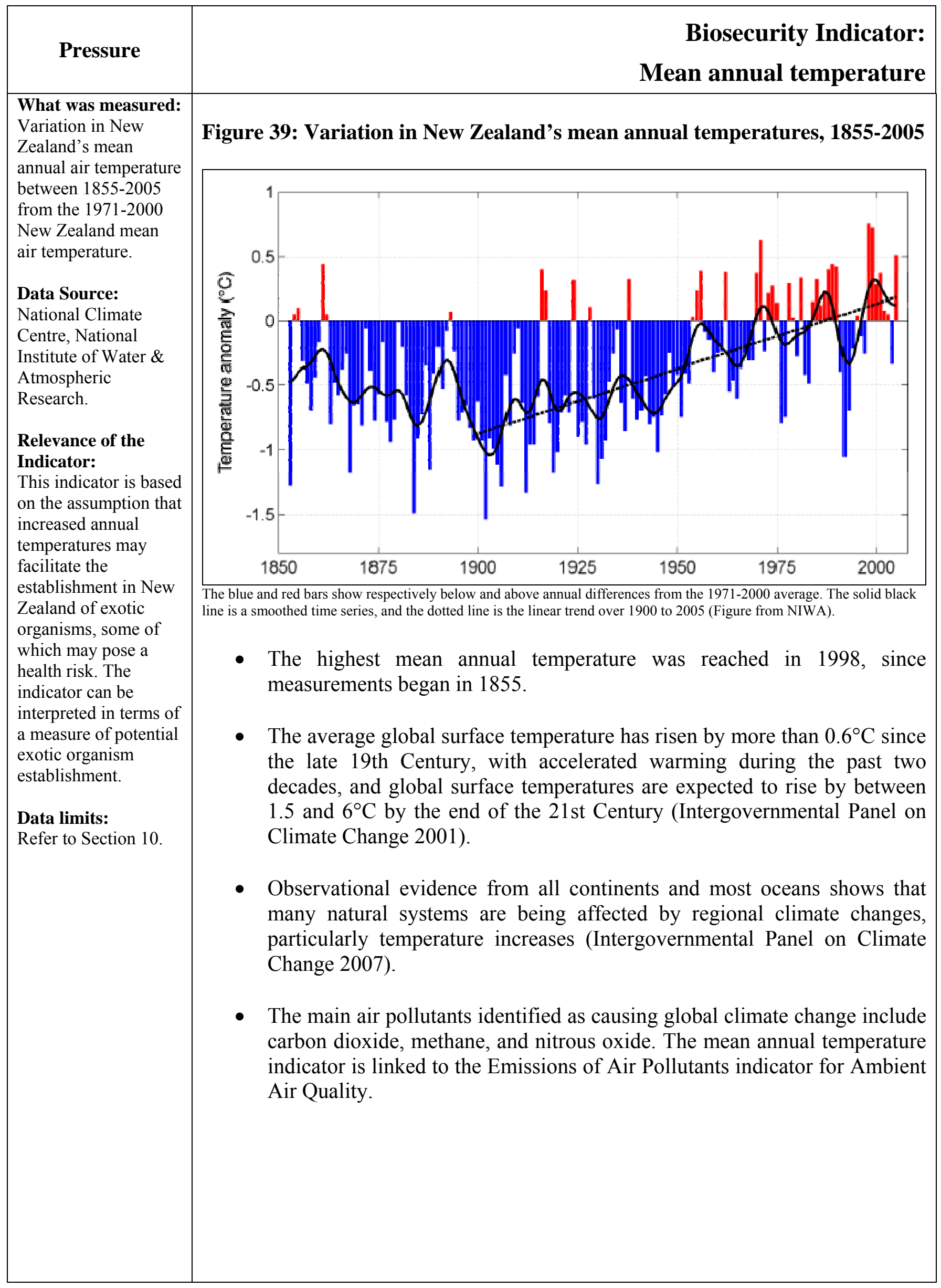




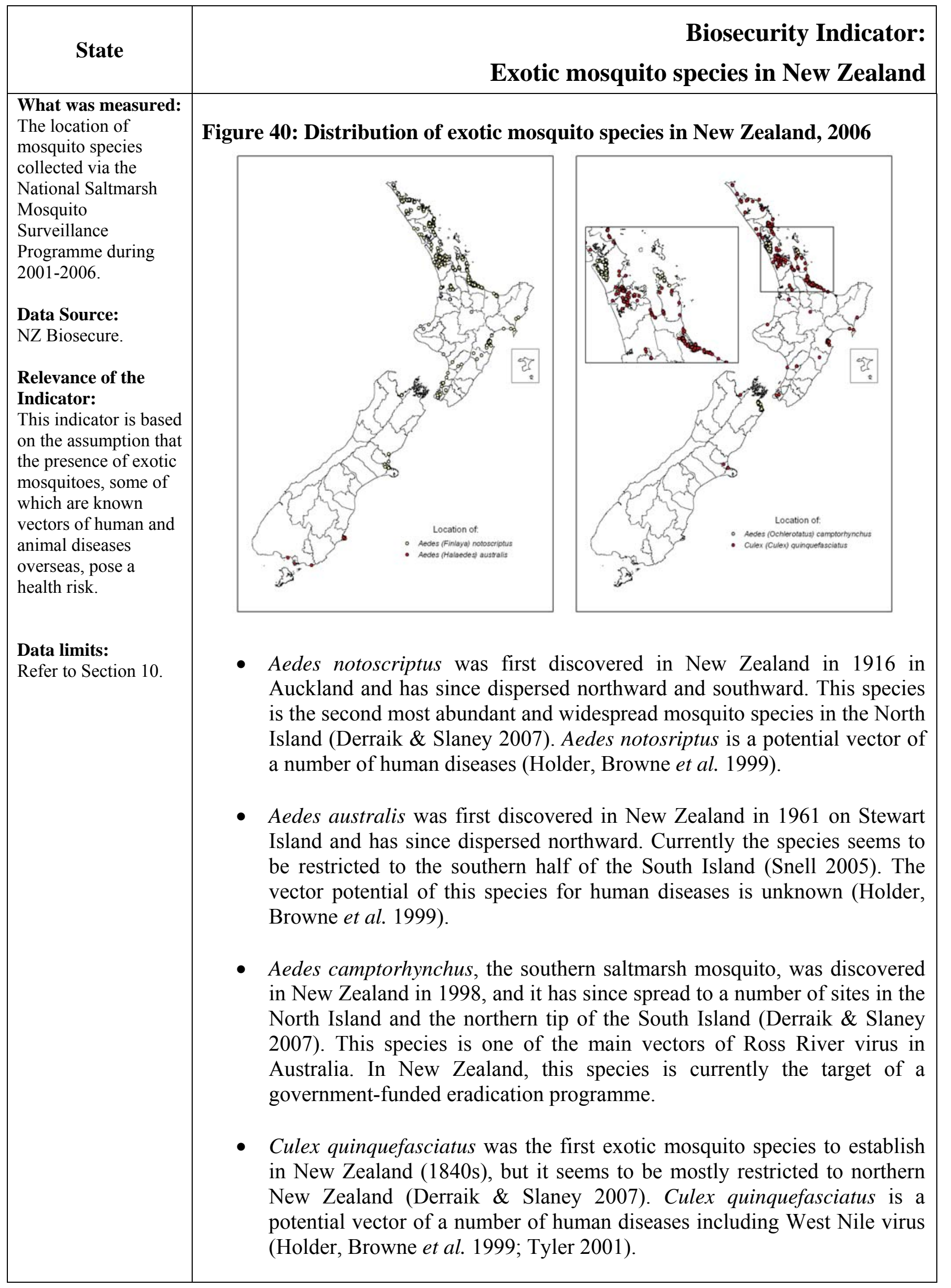




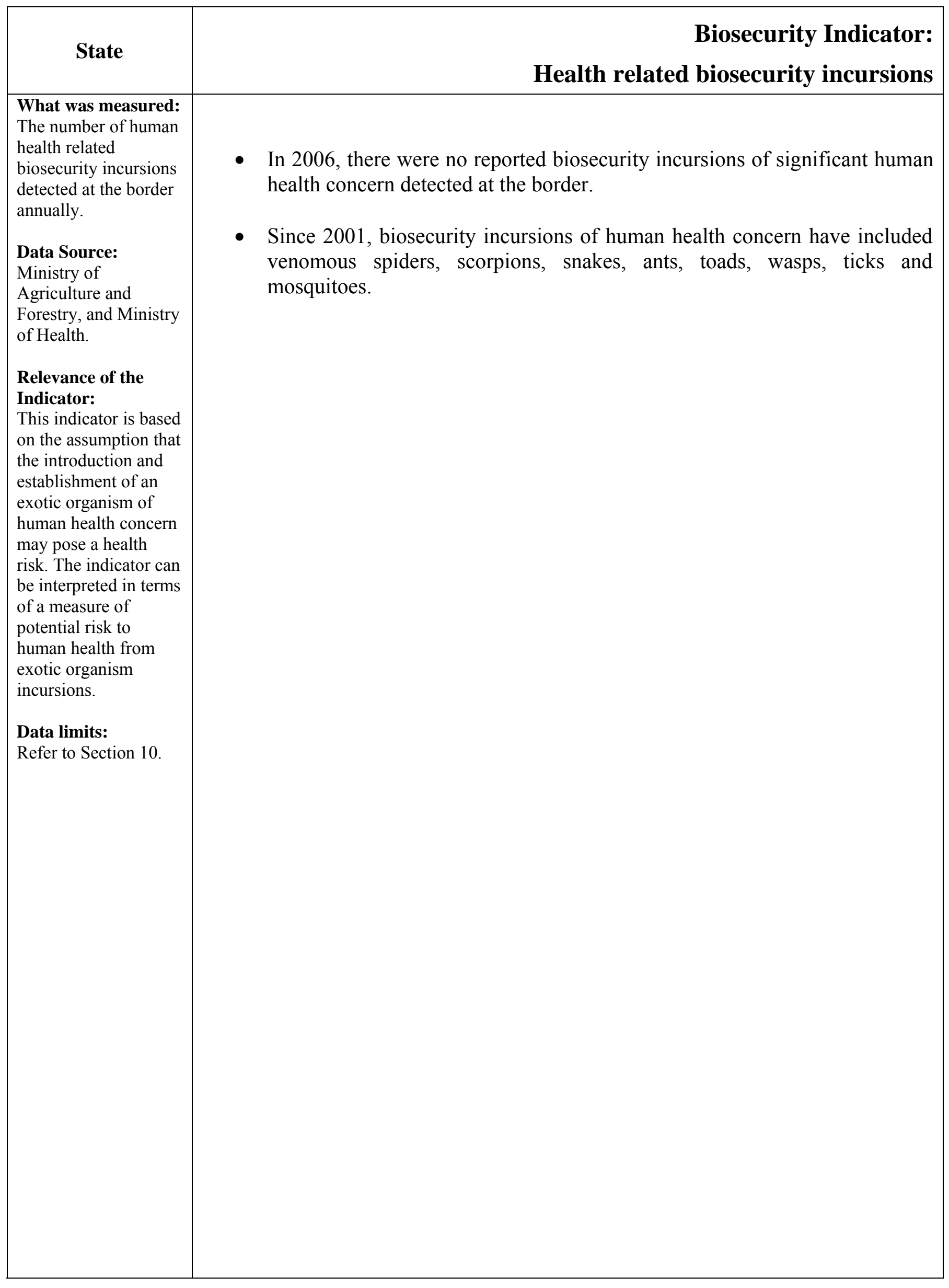




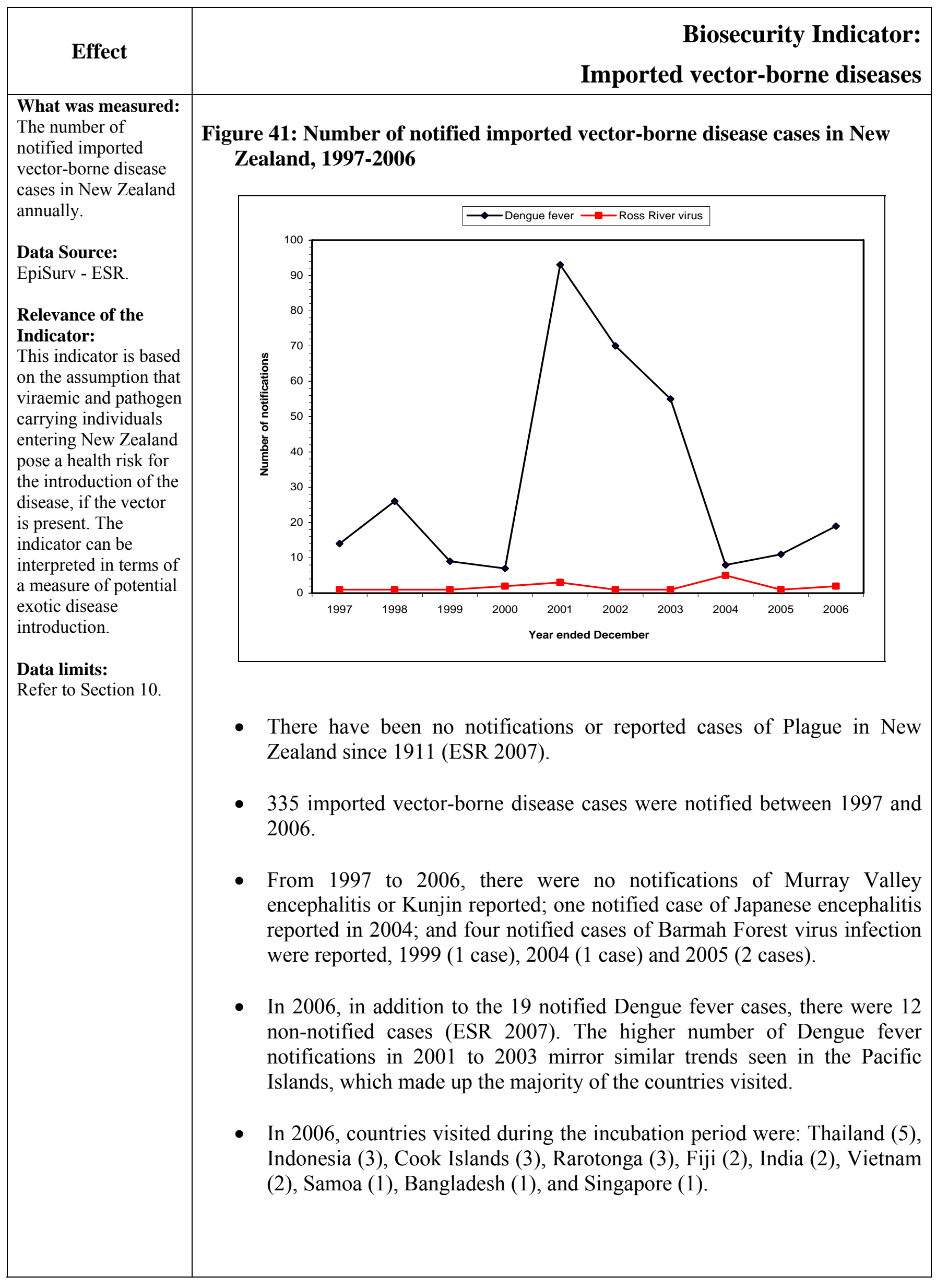




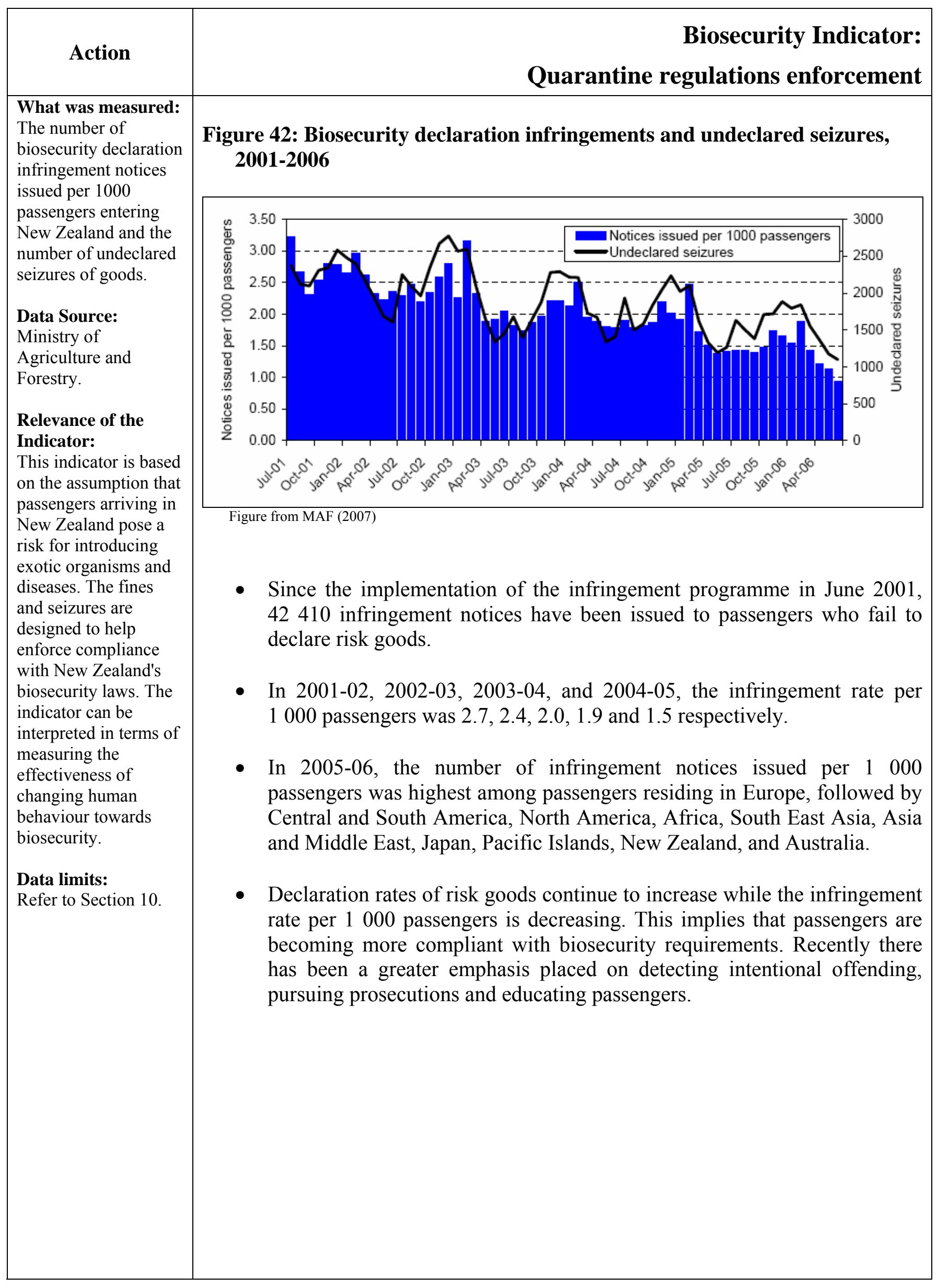




\section{FUTURE DIRECTIONS FOR EHIS}

For the EHI programme to be successful research initiatives will need to be coordinated with monitoring and surveillance work. Bridging the gap between the environment and human health will require better detection and evidence of the links between environmental exposures and health outcomes. Resources need to be allocated not only to monitoring, surveillance and research activity, but also to analysis, risk assessment and integration with actions.

Next steps for this project could include:

- Ongoing maintenance of current indicators.

- Development of new indicators to include new areas e.g. housing.

- Development within current indicator areas to include emphasis on ethnic and socioeconomic disparities.

- Annual reports focussing on selected case studies - highlighting issues with developments driven by policies, public concern, economic activities etc.

- Co-ordinate environmental health surveillance in a few selected locations.

- Maintain an online up to date environmental health repository.

- Monitor the literature on the evidence base between EHIs and health outcomes.

Figure 43: Research \& Development within the DPSEEA Framework

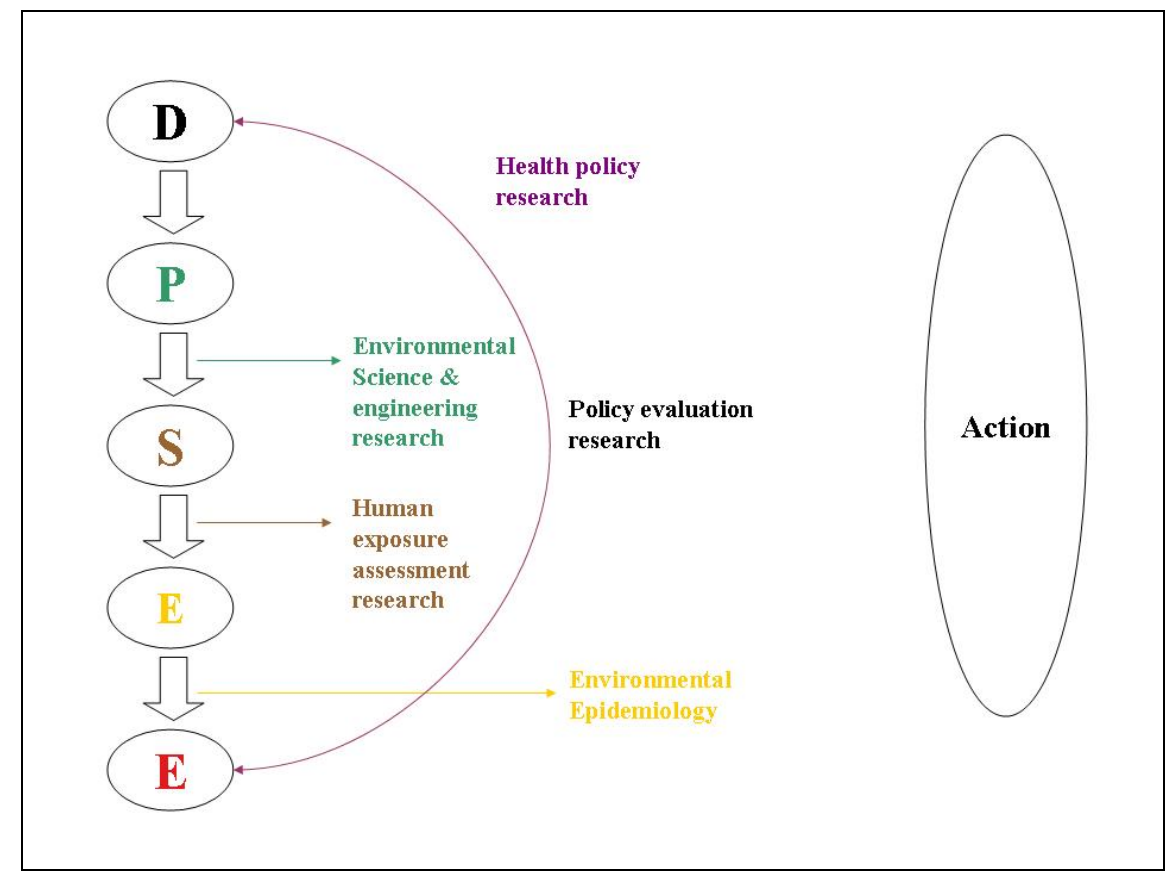




\section{DATA ISSUES, QUALITY AND GAPS}

\section{General}

All the data presented in this report were obtained from sources external to ESR and were collected primarily for purposes other than for this report. All analyses in this report are based on data obtained prior to June 2007. Each of these datasets has its own structure and processes and therefore own data quality issues. There are therefore several general issues which need mention and consideration with regard to the data presented in this report. These include:

\section{Data Availability}

There are several limitations to the availability of data sets, e.g. there are:

- Times and locations within New Zealand at which data are not collected.

- Significant variations in the time period between data collection and data availability.

- Situations where data that have been collected cannot be accessed, for a variety of reasons.

For this report a wide variety of data sources have been sought to develop as comprehensive a picture as possible. Data gaps are noted as appropriate in the individual indicator sheets.

\section{Data Consistency}

Similarly, there are several limitations with respect to the consistency of data, these include:

- Variation in geographical boundaries over time and between agencies making time trend analysis imprecise. Where area boundary definitions have remained largely consistent rates of environmental compliance and health outcomes over time have been compared. However there will be small overlaps in the population being compared. Conversely when area definitions used for different types of data did not match, rates between areas were not able to be compared.

- This report relied on the definitions applied by the organisations collecting the data. For example, individual officers investigating an outbreak or case of communicable disease may apply the criteria used to define pathogen sources differently. This may result in a greater percentage of cases attributed to one source e.g. water, than another e.g. food.

- Variations in sampling protocols mean that data are not directly comparable between some areas and countries. These differences in sampling protocols have been listed when they are meaningful and apparent.

- Data collected on EpiSurv are entered by the respective Public Health Unit. Differences between areas with regard to the percentage of disease cases diagnosed in comparison to the number of cases of disease contracted (and not reported) cannot be estimated. This may have a significant impact on the observations. However it should be remembered that since over-reporting is not an issue with EpiSurv data (duplicates are identified and removed), reported data are either underestimates resulting from under-reporting, or true rates in those areas. Note that cases of waterborne diseases were counted only if they were clinically observed and laboratory confirmed. 


\section{Data Comparability}

Inconsistencies in and the lack of data collection, make it difficult to report and compare results across time and locations, as discussed above. Where these have been adequately addressed, comparisons have been made.

It is important to note that there is temporal variation for the indicators included in this report. Therefore caution is require when comparing indicators from different years as population denominator data many vary.

Despite the limitations of the datasets, the collation of the data and the derivation of the various EHIs still have many merits, as its purpose is to examine general trends and relationships at a national level and through the use of consistent methodologies benchmark New Zealand internationally. It is not designed to be used as de facto epidemiological evidence.

Intra New Zealand differences may also highlight the need for a more consistent and systematic approach to data quality across organisational and geographic boundaries.

\section{Water Quality Indicators}

\section{Land use}

Further information: http://www.maf.govt.nz/mafnet/

\section{Livestock numbers}

Data limits:

http://www2.stats.govt.nz/domino/external/omni/omni.nsf/bf3c32a862ae07cd4c2565e000031c6 /5f560be9a9f8b1eccc2572ae001492a2?OpenDocument\#Glossary

\section{Further information: http://www.stats.govt.nz}

\section{Wastewater treatment}

\section{Data limits:}

This indicator is based on CoSINZ data collected via survey in 2000-2001. The data is restricted to information provided by survey respondents, not the total New Zealand population. This survey did not include communities of less than 100 people.

\section{Further information: http://www.drinkingwater.co.nz/}

\section{Drinking water quality}

Data limits:

Data on exceedances may be subject to large margin of error due to inconsistencies in reporting, sampling practices, analytical methods used, etc.

Further information: http://www.drinkingwater.co.nz/default.asp

\section{Recreational water quality}

Data limits:

Data on exceedances may be subject to large margins of error due to inconsistencies in reporting and sampling practices. The data is only representative of the sites monitored and not of New Zealand as a whole. There is a large variation in the intensity of monitoring throughout New Zealand. For this indicator the bathing season is $1^{\text {st }}$ November to $31^{\text {st }}$ March. 
Further information:

http://www.mfe.govt.nz/state/reporting/recreational-water/snapshot.html

\section{Population access to safe drinking water}

Data limits:

- Numerator: Population access to safe drinking water data is an estimate by the TLA of the number of people in each drinking water zone. The data may be affected by occasional use premises (rural schools, hotels, camping ground etc) and seasonal fluctuations (resource and holiday destinations).

- Denominator: 2005 estimated population data.

Further information: http://www.drinkingwater.co.nz/default.asp

\section{Drinking waterborne diseases rate/Outbreaks of drinking waterborne diseases \\ Data limits:}

Care needs to be taken due to inherent inconsistencies and inaccuracies in the available data. The disease rate does not reflect the true burden of disease due to under reporting of waterborne disease and the large number of gastrointestinal diseases of unknown origin. Data collected on EpiSurv are entered by the Public Health Units. Differences between areas with regard to the percentage of disease cases diagnosed in comparison to the number of cases of disease contracted (and not reported) cannot be estimated. This may have a significant impact on the observations. However it should be remembered that since over-reporting is not an issue with EpiSurv data (duplicates are identified and removed), reported data either underestimates resulting from under-reporting, or true rates in those areas. Note that cases of waterborne diseases are counted only if they were clinically observed and laboratory confirmed.

As referred to in the individual indicator sheet on pages $20 \& 22$, these indicators measure notifications of diseases, which recorded either drinking water or recreational water exposure (excluding swimming and spa pools) as a risk factor for transmission.

Rates based on Census 2006 population data.

Further information: http://www.surv.esr.cri.nz/

\section{Recreational waterborne diseases rate/Outbreaks of recreational waterborne diseases \\ Data limits:}

Recreational water for this indicator includes both marine and freshwater due to the nature of the data in EpiSurv i.e. it is not possible to distinguish between marine and fresh waterborne disease cases. Care needs to be taken due to inherent inconsistencies in the available data. The disease rate does not reflect the true burden of disease due to under reporting of recreational waterborne diseases and the large number of gastrointestinal diseases of unknown origin. Also refer to data limits for drinking waterborne diseases rate.

Rates based on Census 2006 population data.

Further information: http://www.surv.esr.cri.nz/ 


\section{Air Quality}

\section{Fuel consumption}

Data limits:

Consumer energy is used by final consumers. It excludes energy used or lost in transformation and in brining the energy to the final consumer. For example, natural gas is a source of primary energy, some of which is transformed into electricity, of which some is used or lost in transmission and distribution to consumers.

Further information: http://www.med.govt.nz/

\section{Home heating}

Data limits:

- Based on Census 2006 data and updated once in five years.

- Dwellings may use more than one fuel type to heat their home.

Further information:

http://www.stats.govt.nz/census/2006-census-data/quickstats-about-housing/quickstats-abouthousing-revised.htm

\section{Vehicle kilometres travelled}

Further information: http://www.mot.govt.nz/home/

\section{Ambient air quality}

Data limits:

Knowledge about air pollution is constrained by the limited extent of air quality monitoring carried out. The councils that do not monitor the air daily may have a higher or lower than the actual annual mean. Available data is limited to specific monitored sites and times, the location of the monitoring site has an impact on the severity of the pollution. The instrument used for instance TEOM tend to underestimate $\mathrm{PM}_{10}$. At present the large variation in monitoring intensity throughout New Zealand means that there is a plethora of data for some sites and a paucity for others.

Further information: http://www.mfe.govt.nz/issues/air/

\section{Gas heating}

Data limits:

- Based on Census 2006 data and updated once in five years.

- Dwellings may use more than one fuel type to heat their home.

- It is not possible to determine the proportion of flued and unflued gas heaters being used. It is the use of unflued gas heaters that influences indoor air quality.

Further information:

http://www.stats.govt.nz/census/2006-census-data/quickstats-about-housing/quickstats-abouthousing-revised.htm

\section{Hospitalisation and mortality rates due to respiratory diseases/circulatory}

diseases/asthma

Data limits:

- Hospitalisation rates based on Census 2006 population data.

- Mortality rates based on Census 2001 population data.

http://www.nzhis.govt.nz/documentation/index.html 
Further information: http://www.nzhis.govt.nz/

\section{Prescription rate for asthma medication}

Data limits:

- This indicator assumes that diagnosed cases have equal access to prescription drugs in differing socioeconomic parts of the country.

- Individuals may have numerous prescriptions per year.

- Rates based on 2005 estimated population data.

Further information: http://www.nzhis.govt.nz/collections/collections-pharmhouse.html

\section{$\underline{\text { Road Transport }}$}

\section{Means of travel to work}

Data limits:

Based on what was recorded by an individual on their census form as their main means of travel to work. Main means of travel to work is the method by which the respondent, aged 15 years and over, travelled the longest distance to their main employment on 7 March 2006, e.g. by bicycle, bus, walking or jogging.

Further information:

http://www.stats.govt.nz/census/2006-census-data/classification-counts/about-people/mainmeans-of-travel-to-work.htm

\section{Vehicle kilometres travelled}

Further information: http://www.mot.govt.nz/home/

\section{Mean age of vehicle fleet}

Data limits:

There is a large variation in age of cars as in some areas, there might be very old cars which may not be regularly used as the main means of transport. Some older cars may be better than newer cars if they are serviced more regularly.

\section{Further information: http://www.ltsa.govt.nz/}

\section{Serious injury and mortality rates due to road transport accidents \\ Data limits:}

The crash data are derived from Traffic Crash Reports completed by Police officers who attend fatal and injury crashes. However, comprehensive hospital based surveys indicate that only about one half of such injury crashes are reported. The most serious under-reporting is amongst single vehicle crashes, motorcycle crashes and crashes involving alcohol. There is a reporting bias by day of week and by hour of day and by region. Regional rates may be affected by the density of police activity as this has a significant impact on the reporting of traffic injury rates. TLA refers to the location of the motor vehicle accident.

Motor vehicle crash - Any crash that occurs on a public road that is attributable directly or indirectly to a motor vehicle or its load. Crashes which do not occur on public roads are excluded e.g. tractor crashes on farms are not included. The data includes only crashes that involve a motor vehicle. A crash between a cyclist and a pedestrian, for example, would not be included. 
Serious injuries - Fractures, concussion, internal injuries, crushings, severe cuts and lacerations, severe general shock necessitating medical treatment and any other injury involving removal to and detention in hospital.

Fatal injuries - Up to and including 1974 comprised injuries that resulted in death within 28 days of the crash. From, and including, 1975 they comprise injuries that result in death within 30 days of the crash. This is consistent with the international definition.

Exclusions: There are a number of cases where road deaths or motor vehicle deaths are not included in the official road toll. They include:

- Deaths that do not occur on a public road or a road to which the public has access (e.g. race track or farm paddock).

- Deaths that did not result from injuries sustained in the crash (e.g. when the coroner determines that a driver died from a heart attack).

- Suicide or murder.

- Deaths on the road where a motor vehicle was not involved (e.g. cyclist only crash). These definitions are in line with the most common international definitions. Although these deaths are excluded from the official road toll a record is kept of the crash details.

Factors contributing to crashes - On each crash report up to three factors can be coded against each vehicle involved in the crash for driver, passenger or vehicle faults. In addition up to three factors can be coded on each report for faults of other road users, weather or other conditions.

Rates based on Census 2006 population data.

Further information: http://www.transport.govt.nz/home/

\section{PYLL due to road transport accidents}

Data limits:

- This indicator is influenced by the quality of the traffic mortality data.

- Rates based on Census 2006 population data.

Further information: http://www.euro.who.int/violenceinjury/about/20050208 1

\section{Biosecurity}

\section{Overseas Cargo (gross weight) unloaded}

Data limits:

Inclusions:

- Goods which add to the stock of material resources in New Zealand as a result of their movement into the country (also included as part of merchandise trade)

- Goods being returned after repair or modification from overseas

- Goods on short-term loan or lease

- Replacements

- Returnable containers

- Returnable samples

- Short shipped goods

- Data provisional for end June 2006. 
Exclusions:

- Large one-off imports of transport equipment, i.e. aircraft, shipping vessels, oil rigs etc, that arrive in or depart from the country under their own power (also included as part of merchandise trade)

- Goods imported for use by foreign armed forces

- Goods imported for official representatives of overseas countries (other than motor vehicles)

- Consignments valued under $\$ 1000$

- Goods in transit or trans-shipment goods

- Ships and aircraft on commercial visits

- Currency transactions in gold, silver and current coin

- Passengers' baggage (other than dutiable imports)

- Fish and other sea products landed in New Zealand

- Temporary imports into New Zealand (e.g. yachts visiting New Zealand) for which goods and services tax (GST) is not payable.

Further information: http://www.stats.govt.nz/economy/exports-and-imports/overseascargo.htm

\section{Imports (by risk goods)}

Data limits:

- This indicator is currently limited to used vehicles and machinery and does not include other risk goods e.g. used tyres.

- For 2000-2002, figures refer to used vehicles only.

- Data obtained from the June issues of the MAF Biosecurity New Zealand Surveillance magazine (Annual Reports) and MAF Biosecurity Monitoring Group.

Further information: http://www.biosecurity.govt.nz/publications/surveillance/index.htm

\section{International Vessel Arrivals}

Data limits:

- Data obtained from the June issues of the MAF Biosecurity New Zealand Surveillance magazine (Annual Reports).

Further information: http://www.biosecurity.govt.nz/publications/surveillance/index.htm

\section{International Passenger Arrivals}

Data limits:

- These statistics are based on final counts of arrivals to New Zealand, and include overseas visitors and New Zealand residents, but not crew.

- Multiple movements of individual people during a given reference period are each counted as separate arrivals.

- Includes length of stay of less than 12 months, overseas migrants intending to stay 12 months or more (or permanently), and New Zealand residents returning after an absence of 12 months or more.

- Short-term migration data for the years 1975-1996 and up to August 1997 are sampled data. Actual counts of passengers are from September 1997 onwards.

Further information: http://www.stats.govt.nz/products-and-services/info-releases/externalmigration-info-releases.htm 


\section{Overseas Disease Outbreaks}

Data limits:

- Only includes disease outbreaks of significant interest reported to WHO.

- Data restricted to human cases of disease, unless deemed important e.g. birds for H5N1.

- Only confirmed outbreaks are reported.

- If an outbreak started in 2005 and carried over into 2006 it is listed in the table.

Further information: http://www.who.int/csr/don/en/

\section{Mean annual temperature}

Data limits:

- Calculations of climate change for specific areas are much less reliable than global ones, and it is unclear whether regional climate will become more variable.

- Although there are a number of uncertainties regarding current and predicted climate change, the Intergovernmental Panel on Climate Change state "There is new and stronger evidence that most of the warming observed over the last 50 years is attributable to human activities" (Intergovernmental Panel on Climate Change 2001, 2007).

Further information: http://www.niwascience.co.nz/ncc/clivar/pastclimate http://www.ipcc.ch

\section{Exotic mosquito species in New Zealand}

Data limits:

- Only includes mosquito surveillance data collected by NZ Biosecure as part of the National Saltmarsh Mosquito Surveillance Programme from 2001-2006 i.e. no historical collection/distribution data are included.

- For Aedes camptohynchus (the southern saltmarsh mosquito), only sites where the species is currently present are depicted on the map.

Further information: http://www.smsl.co.nz/docs/PageTemplate.asp?PageID $=6$

\section{Health related biosecurity incursions}

Data limits:

- Only includes incursions of exotic organisms of significant human health concern reported by the MAF and the MoH via media releases and MAF BNZ Biosecurity magazine and Container-watch publications.

Further information: http://www.maf.govt.nz/mafnet/press/archive/index.htm

http://www.moh.govt.nz/media

http://www.biosecurity.govt.nz/publications/biosecurity-magazine/index.htm

http://www.biosecurity.govt.nz/publications/container-watch/index.htm

\section{Imported vector-borne diseases}

Data limits:

- Includes Dengue fever, Ross River virus, Murray Valley encephalitis (also known as Australian encephalitis), Kunjin, Japanese encephalitis, Barmah Forest virus, and Plague.

- Only human notifiable cases from EpiSurv are included.

- Only vector-borne diseases for which there are vectors present in New Zealand are included. 
- Only diseases for which New Zealand is designated free of are included.

Further information: http://www.surv.esr.cri.nz/surveillance/annual surveillance.php

\section{Quarantine regulations enforcement}

Data limits:

- These statistics are based on final counts of arrivals to New Zealand by air, and include overseas visitors, New Zealand residents and crew.

Further information: http://www.biosecurity.govt.nz/ 


\section{REFERENCES}

Aron, J. \& Patz, J. (eds.). (2001). Ecosystem Change and Public Health: A Global Perspective. Johns Hopkins University Press, Baltimore.

Auckland Regional Council. (2004). Environmental Awareness Survey 2003/2004. Auckland Regional Council, Auckland.

Audit Office. (2002). Ministry of Agriculture and Forestry: Management of Biosecurity Risks. Report of the Controller and Auditor-General. Office of the Auditor-General, Wellington.

Biosecurity Council. (2003). Tiakina Aotearoa Protect New Zealand: The Biosecurity Strategy for New Zealand. Viewpoint Communications, Wellington.

Blows, S., Ivers, R., Woodward, M., Connor, J., Ameratunga, S. \& Norton, R. (2003). "Vehicle year and the risk of car crash injury." Injury Prevention, 9(4): 353-6.

Briggs, D., Corvalan, C. \& Nurminen, M. (1996). Linkage methods for environment and health analysis. General Guidelines. WHO/UNEP/USEPA, Geneva.

Bruntland, G. (ed.). (1987). Our common future: The World Commission on Environment and Development. Oxford University Press, Oxford.

Cabelli, V., Dufour, A., McCabe, L. \& Levin, M. (1982). "Swimming associated gastroenteritis and water quality." American Journal of Epidemiology, 115: 606-616.

Cohen, A., Ross, A., Ostro, B. et al. (2005). "The global burden of disease due to outdoor air pollution." J Toxicol Environ Health A. Jul 9 - 23;68(13-14):1301-1307.

Corvalan, C. \& Kjellstrom, T. (1995). "Health and environment analysis for decision making." World Health Statistics Quarterly, 48(2): 71-7.

Davies-Colley, R., Nagels, J., Smith, R, Young, R. \& Phillips, C. (2004). "Water quality impact of a dairy cow herd crossing a stream." New Zealand Journal of Marine and Freshwater Research, 38: 569-576.

Derraik, J. \& Slaney, D. (2007). "Anthropogenic Environmental Change, Mosquito-Borne Diseases and Human Health in New Zealand." EcoHealth, 4(1): 72-81.

de Wet, N., Slaney, D., Ye, W., Warrick, R \& Hales, S. (2005). Hotspots: Exotic mosquito risk profiles for New Zealand. International Global Change Institute, University of Waikato, Hamilton and Ecology and Health Research Centre, University of Otago, Wellington.

enHealth Council. (2002). Developing national environmental health indicators. Department of Health and Ageing, Canberra.

Environment Canada. (2002). Developing environmental public health indicators in Canada, Environment Canada - Health Canada \& Canadian Institute for Health Information. 
ESR. (2007). Notifiable and Other Diseases in New Zealand, Annual Report 2006. ESR, Wellington.

Frampton, E. (2005). Pathways of Entry and Spread of Exotic Mosquitoes, With Particular Reference to Southern Saltmarsh Mosquito, Ochlerotatus camptorhynchus. Report for New Zealand Ministry of Health, Wellington.

Gouveia, N. \& Fletcher, T. (2000). "Time series analysis of air pollution and mortality: effects by cause, age and socioeconomic status." J Epidemiol Community Health. Oct; 43(10):750-755.

Hanson, C. \& Hayward, S. (2004). Nitrate contamination of groundwater in the AshburtonRakaia plains. Report No. R04/09, prepared for Environment Canterbury, Christchurch.

Holder, P., Browne, G. \& Bullians, M. (1999). "The mosquitoes of New Zealand and their animal disease significance." Surveillance, 26: 12-15.

Hughey, K., Kerr G. \& Cullen, R. (2006). Public Perceptions of New Zealand's Environment: 2006. EOS Ecology, Christchurch.

Intergovernmental Panel on Climate Change. (2001). Climate Change 2001: The Scientific Basis. Contribution of Working Group I to the Third Asssessment Report of the Intergovernmental Panel on Climate Change [J. Houghton, Y. Ding, D. Griggs, M. Noguer, P. van der Linden, X. Dai, K. Maskell, and C. Johnson (eds.)]. Cambridge University Press, United Kingdom and New York.

Intergovernmental Panel on Climate Change. (2007). Climate Change 2007: Impacts, Adaptation and Vulnerability. Summary for Policymakers. Working Group II Contribution to the Intergovernmental Panel on Climate Change Fourth Assessment Report [Online]. Available: http://www.ipcc.ch [2007, April 16].

Jeanne Breen Consulting. (2004). Review of the Road Safety to 2010 Strategy: Final report.

Kay, D., Fleisher, J., Jones, F., Salmon, R., Wyer, M., Godfree, A., Zelenauch-Jacquotte, Z. \& Shore, R. (1994). "Predicting the likelihood of gastro-enteritis from sea bathing: results from randomised exposure." Lancet, 344: 905-9.

King, A. (2007a). Opportunities ahead for public transport [Online]. Available: http://www.beehive.govt.nz/ViewDocument.aspx?DocumentID=28470 [2007, June 7].

King, A. (2007b). Regional fuel taxes will benefit all road users [Online]. Available: http://www.beehive.govt.nz/ViewDocument.aspx?DocumentID=29478 [2007, June 7].

Kjellstrom, T. \& Corvalan, C. (1995). "Framework for the development of environmental health indicators." World Health Statistics Quarterly, 48(2): 144-154.

Kjellstrom, T. \& Hill, S. (2002). New Zealand Evidence for Health Impacts of Transport; A background paper prepared for the Public Health Advisory Committee.

Land Transport Safety Authority. (2003). Road safety to 2010. Land Transport Safety Authority, Wellington. 
Larned, S., Scarsbrook, M., Snelder, T. \& Norton, N. (2005). Nationwide and regional state and trends in river water quality 1996-2002. NIWA report for Ministry for the Environment, Wellington.

Lounibos, L. (2002). "Invasions by insect vectors of human disease." Annual Review of Entomology, 47: 233-266.

Ministry for the Environment. (1997). The State of New Zealand's Environment. Ministry for the Environment, Wellington.

Ministry for the Environment. (2002). Microbiological Water Quality Guidelines for Marine and Freshwater Recreational Areas. Ministry for the Environment, Wellington.

Ministry for the Environment. (2004a). Water Programme of Action. The Effects of Rural Land Use on Water Quality. Ministry for the Environment, Wellington.

Ministry for the Environment. (2004b). Water Bodies of National Importance: Potential water bodies of national importance for recreation value. Ministry for the Environment, Wellington.

Ministry for the Environment. (2005). New Zealand Urban Design Protocol. Ministry for the Environment, Wellington.

Ministry for the Environment. (2007). National environmental standards: airsheds. [Online]. Available: http://www.mfe.govt.nz/laws/standards/airsheds/index.html [2007, June 7].

Ministry of Agriculture and Forestry. (2006). What is biosecurity [Online]. Available: http://www.biosecurity.govt.nz/strategy-and-consultation/strategy/progress [2006, June 20].

Ministry of Agriculture and Forestry. (2007). Pathway Analysis Annual Report 2005-06. Biosecurity Monitoring Group, Biosecurity New Zealand, Ministry of Agriculture and Forestry, Wellington BMG 05-06/12.

Ministry of Health. (1999a). Progress on health outcome targets 1999. Ministry of Health, Wellington.

Ministry of Health. (1999b). Our Health, Our Future: Hauora Pakari, Koiora Roa: The Health of New Zealanders 1999. Ministry of Health, Wellington.

Ministry of Health. (2000). Social inequalities in health, New Zealand 1999: a summary. Ministry of Health, Wellington.

Ministry of Health. (2003). Achieving health for all people - Whakatutuki te oranga hauora mo ngä tängata katoa: a framework for public health action for the New Zealand Health Strategy. Ministry of Health, Wellington.

Ministry of Social Development. (2006). The social report: indicators of social wellbeing in New Zealand. Ministry of Social Development, Wellington.

Ministry of Transport. (2005). Getting there - on foot, by cycle: A strategy to advance walking and cycling in New Zealand transport. Wellington. 
Ministry of Transport. (2007). Visible smoke check [Online]. Available: http://www.transport.govt.nz/visible-smoke-check/ [2007, June 7].

Morrison, D., Petticrew, M. \& Thomson, H. (2003). "What are the most effective ways of improving population health through transport interventions? Evidence from systematic reviews." Journal of Epidemiology \& Community Health, 57(5): 327-333.

Pastides, H. (1995). "An epidemiological perspective on environmental health indicators." World Health Statistics Quarterly, 48(2): 140-3.

Pope, C. $3^{\text {rd }}$, Dockery, D., Spengler, J. \& Raizenne, M. (1991). "Respiratory health and PM 10 pollution. A daily time series analysis." American Review of Respiratory Disease, 144(3): 668-674.

Pope, C. $3^{\text {rd }}$, Burnett, R., Thun, M., Calle, E., Krewski, D., Ito, K. \& Thurston, G. (2002). "Lung cancer, cardiopulmonary mortality, and long-term exposure to fine particulate air pollution." Journal of the American Medical Association, 287(9): 1132-41.

Pruss, A., Kay, D., Fewtrell, L. \& Bartram, J. (2002). "Estimating the Burden of Disease from Water, Sanitation, and Hygiene at a Global Level." Environmental Health Perspectives, 110(5): 537-542.

Rogers, D. \& Randolph, S. (2006). "Climate Change and Vector-Borne Diseases." Advances in Parasitology, 62: 345-381.

Salinas, M. \& Vega, J. (1995). "The effect of outdoor air pollution on mortality risk: an ecological study from Santiago, Chile." World Health Statistics Quarterly. 48(2):118-125.

Samet, J., Domenici, F., Curriero, F. et al. (2000). "Fine particulate air pollution and mortality in 20 U.S. cities, 1987 - 1994." N Engl J Med 2000 Dec 14;343(24):1742-1749.

Simpson, R., Willians, G., Petroeschevsky, A., et al. (1997). "Associations between outdoor air pollution and daily mortality in Brisbane, Australia." Arch Environ Health. NovDec;52(6):442-444.

Smith, C., Wilcock, R., Vant, W. \& Cooper, A. (1993). Towards sustainable agriculture: Freshwater quality in New Zealand and the influence of agriculture, NIWA Ecosystems report for MAF Policy and Ministry for Environment. MAF Policy Technical paper 93/10.

Snelder, T. \& Scarsbrook, M. (2005). Spatial patterns in state and trends of environmental quality in New Zealand rivers: an analysis for State of Environment reporting. NIWA report for Ministry for the Environment, Wellington.

Snell, A. (2005). "The discovery of the exotic mosquito Ochlerotatus australis and the endemic Opifex fuscus (Diptera: Culicidae) on North East Island, Snares Island. The Weta, 30: $10-13$.

Spix, C., Anderson, H., Schwartz, J., Vigotti, M., LeTertre, A., Vonk, J., et al. (1998). "Short-term effects of air pollution on hospital admissions of respiratory diseases in Europe: a quantitative summary of APHEA study results. Air Pollution and Health: a European Approach." Arch Environmental Health, 53: 54-64. 
Statistics New Zealand. (2002). Monitoring progress towards a sustainable New Zealand: An experimental report and analysis. Statistics New Zealand, Wellington.

Tatem, A., Hay, S. \& Rogers, D. (2006). "Global traffic and disease vector dispersal." PNAS, 103(16): 6242-6247.

Tatem, A., Rogers, D. \& Hay, S. (2006). "Global transport networks and infectious disease spread." Advances in Parasitology, 62: 293-343.

The European Charter and Commentary. (1989). Environment and Health. Frankfurt. United Nations. (1992). Report of the United Nations Conference on Environment and Development: Rio Declaration on Environment and Development. United Nations Conference on Environment and Development 3-14 June 1992, Rio de Janeiro, A/CONF.151/26 (vol. 1).

Tizard, J. (2006). Tougher emission standards for imported vehicles [Online]. Available: http://www.beehive.govt.nz/ViewDocument.aspx?DocumentID=28173 [2007, June 7].

Tizard, J. (2007). Government requires biofuels sales [Online]. Available: http://www.beehive.govt.nz/ViewDocument.aspx?DocumentID=28365 [2007, June 7].

TNS. (2007). Quality of Life Survey 2006 National Report. Prepared for Quality of Life Survey Team, New Zealand.

Tyler, K. (2001). "West Nile Virus Encephalitis in America." New England Journal of Medicine, 344: 1858-1859.

United States Environmental Protection Agency. (2006). Air - Indoor Air Quality (IAQ) [Online]. Available: http://www.epa.gov/iaq/index.html [2006, June 22].

von Schirnding, Y. (2002). Health in sustainable development planning: the role of indicators. World Health Organization, Geneva.

Wenzel, T., Singer, B. \& Slott, R. (2000). "Some Issues in the Statistical Analysis of Vehicle Emissions." Journal of Transport and Statistics, September: 1-14.

Wilcock, R. (1986). "Agricultural run-off: a source of water pollution in New Zealand?" New Zealand Agricultural Science, 20: 98-103.

Wilcox, B. \& Colwell, R. (2005). "Emerging and re-emerging infectious diseases: Biocomplexity as an interdisciplinary paradigm." EcoHealth, 2: 244-257.

Wilcox, B. \& Gubler, D. (2005). "Disease ecology and the global emergence of zoonotic pathogens." Environmental Health and Preventive Medicine, 10: 263-272.

Woodward, A., Hales, S. \& de Wet, N. (2001). Climate Change: Potential Effects on Human Health in New Zealand. Report for the Ministry for the Environment as part of the New Zealand Climate Change Programme, Wellington.

World Health Organization. (1997). Health and environment in sustainable development: five years after the Earth Summit. WHO, Geneva. 
World Health Organization. (2000). Attributable mortality per 100000 people by risk factor and WHO subregion. WHO.

World Health Organization. (2003). Health aspects of air pollution with particulate matter, ozone and nitrogen dioxide. Report of WHO working group, WHO, Bonn, Germany.

World Health Organization. (2004a). Environmental and Health Indicators for Europe. A pilot indicator-based report. WHO Regional Office for Europe, Copenhagen, Denmark.

World Health Organization. (2004b). Health Aspects of Air Pollution, Results from the WHO project "Systematic review of health aspects of air pollution in Europe", Copenhagen Denmark.

World Health Organization. (2004c). Road traffic injury prevention [Online]. Available: http://www.who.int/violence_injury_precention/unintentional_injuries/road_traffic/rtip1/en/ [2004, September 27]. 


\section{APPENDICES}

\section{APPENDIX 1: THE DPSEEA FRAMEWORK}

This section explains in detail the various components of the DPSEEA framework. (Corvalan \& Kjellstrom 1995; Kjellstrom \& Corvalan 1995; Pastides 1995; von Schirnding 2002).

\section{Driving Forces}

A number of key factors on the macro scale broadly affect the environmental processes that may ultimately affect human health. For example, macroeconomic policies may have major effects on the environment and on people's health. Trade and fiscal policies may indirectly impact on human health by affecting income levels and distribution, and agricultural or energy policy may affect health by impacting on land, air and water resources. It is often at this level of decision making, i.e. higher up in the framework, that indicators are useful for setting and evaluating policies, as they allow examination of the root causes of problems, even if these are seemingly remote from the issue under consideration. Thus, if the aim is to take effective action at source, indicators that allow tracing of health effects to their underlying cause can be useful and can give an "early warning" of pending environmental problems.

\section{Pressures}

The various driving forces considered above may result in pressures on the environment. Many factors however, including policy context, social attitudes and economic infrastructure, affect the extent to which driving forces are translated into actual pressures on the environment. Pressures are generated by all sectors of economic activity, such as transport, energy, housing, agriculture, industry, tourism and so forth. Pressures can occur from resource extraction, processing of materials and the production, distribution, consumption and release of waste products. An important pressure from the point of view of human health is the release of pollutants into the environment. Many different sources and media such as water, air and soil may be involved. Nevertheless, constraints similar to those discussed above with respect to driving forces also operate at this level: For example, the ability of the environment to absorb the various stresses imposed on it influences the extent to which changes in the state of the environment result.

\section{State}

The state (quality) of the environment may be affected by the various pressures exerted. Some changes may be complex and widespread, affecting almost all aspects of the environment and resulting in effects such as desertification, marine pollution or climate change, while others may be more localized (e.g. contamination of a local water supply). The frequency or magnitude of natural hazards may be increased (e.g. floods, soil erosion), natural resources may be negatively affected (e.g. biodiversity, soil fertility) or the quality of air and water may be affected by pollution. Secondary effects may also occur, since modifications in one area may affect others. New health hazards may be generated at each step.

\section{Exposure}

Even where the state of the environment is unduly affected, people's health and wellbeing may be affected only when they are actually exposed. Many factors determine whether an individual will be exposed, e.g. to pollution in the environment. Pollution levels vary from place to place and over time, and people's activities and behavioural patterns may influence the extent to which they come into contact with the environment. An environmental factor 
may play a major or a minor role in influencing a disease outcome. With low levels of exposure, the factors concerned may more often play a contributory rather than a primary role in causing disease. Improved biological and biochemical markers of exposure should enhance the effectiveness of exposure assessments in the future. Whatever technique is chosen to characterize exposure, account must be taken of the exposure of groups at specific risk, which include the poor, women, children and workers.

\section{Effect}

Once a person has been exposed to an environmental hazard, health effects may manifest themselves which may vary in type, intensity and magnitude depending on the type of hazard, the level of exposure and other factors. The ill-health effects of environmental exposures may be acute, occurring relatively soon after exposure (from a single large dose due to an accident or a spill for example), or they may be chronic, occurring as a result of cumulative exposures over time.

Thus generally speaking, many factors affect the extent to which a hazard in the environment affects human health. The form, duration, intensity and timing of exposure are important, as is the health status, age and genetic make-up of the individual, as well as the quality and accessibility of the health care system.

\section{Actions}

While sound public policy is based on analyses of the best available information, it does not require absolute scientific certainty. Different actions can be taken, targeted at various points in the framework. It would obviously be impossible to reduce all environmental exposures to a level at which the risk to human health is zero. Measures to improve public health must be implemented over time. Such measures may be short term and remedial or longer-term and preventive (e.g. changing personal behaviour and life styles). Measures could take the form of a policy or comprehensive plan of action which outlines the goals to be achieved in improving health and the environment and mechanisms for attaining those goals, such as standards. A prudent policy on acceptable exposure levels is important, however, and such policies should be revised and updated in accordance with new scientific knowledge. This may lead in some cases to the introduction of more stringent standards, while in other cases the standards may be shown to have been unnecessarily restrictive.

Various actions should thus be taken, based on consideration of the nature of the risks, their amenability to control and the public's perceptions of the risks. Indicators of such actions do not illustrate an effect on the environment but reflect efforts to improve the environment and human health. 


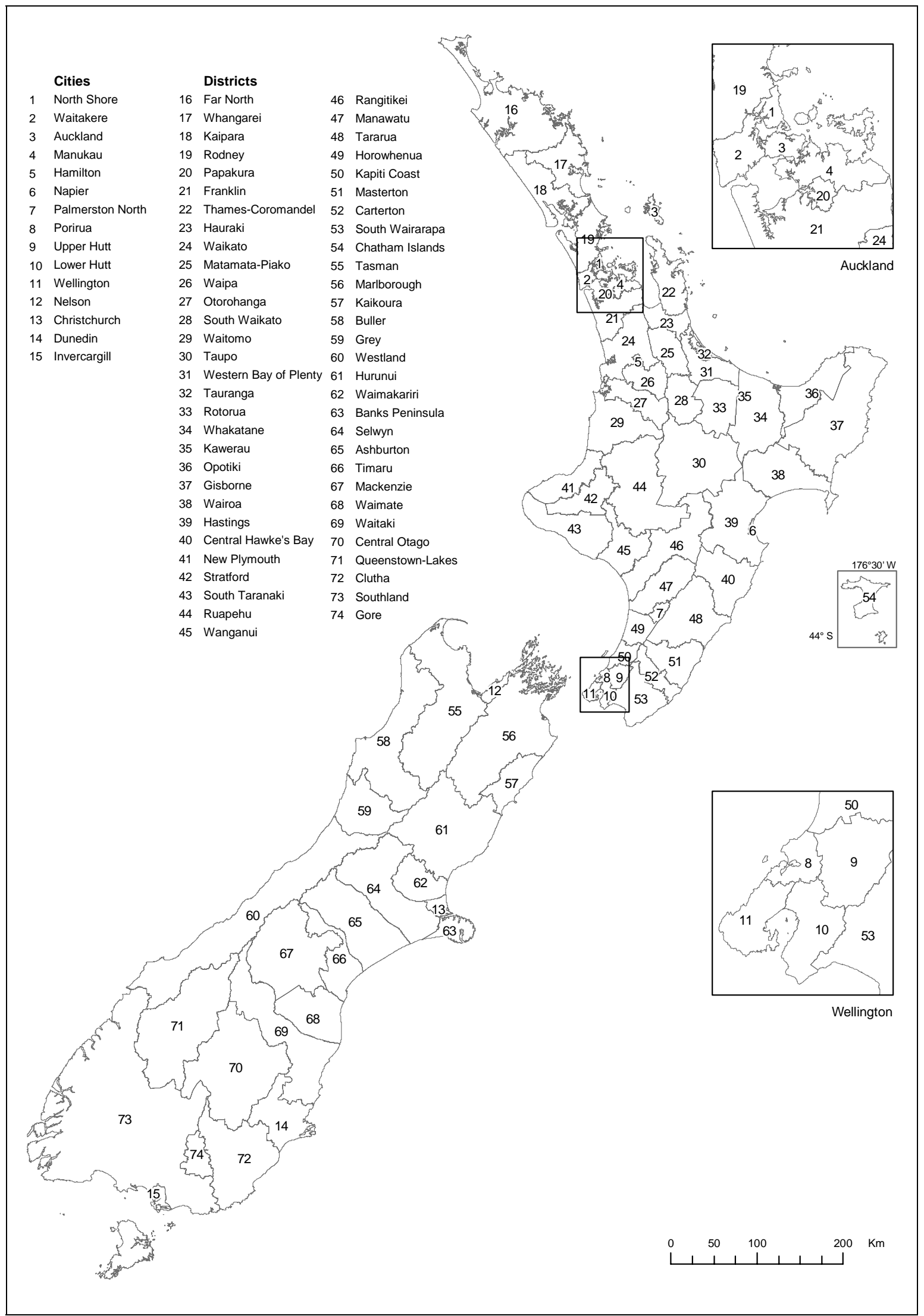




\section{NZ Deprivation 2001 \\ New Zealand by Census Area Units (CAU)}

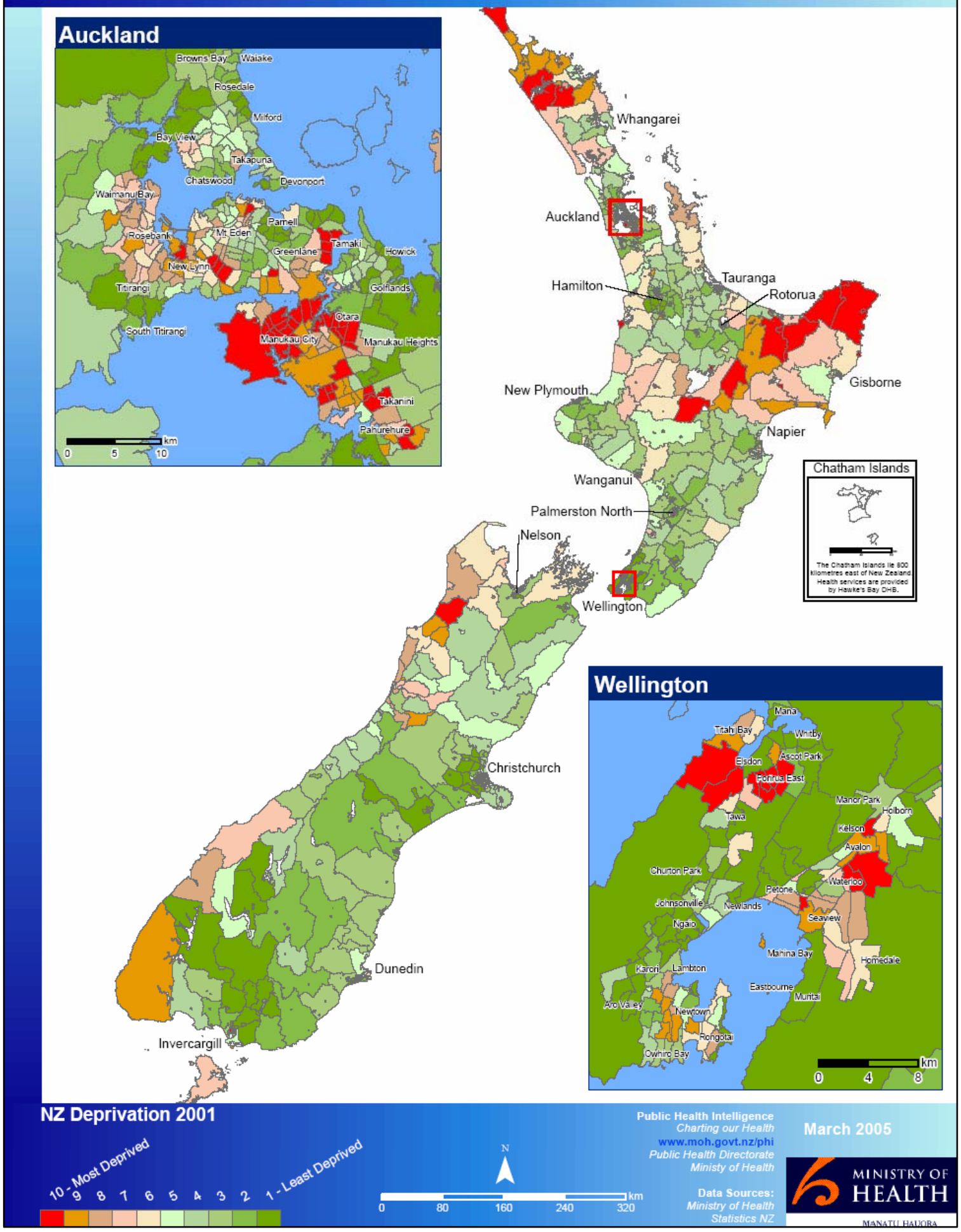

